\title{
William Davenport, the Slave Trade, and Merchant Enterprise in Eighteenth- Century Liverpool
}

Nicholas James Radburn

A thesis submitted in fulfilment of the requirements for the degree of Master of Arts at Victoria University of Wellington 2009 


\section{Table of Contents}

Abstract

Acknowledgments

iii

List of Table and iv

Figures

Introduction

1

Chapter One William Davenport and the Liverpool Slaving 13 Merchant Community

Chapter Two

William Davenport's African Marketing Strategies: Old 42 Calabar and Cameroon

Chapter Three William Davenport's Business Profits

Conclusion 108

Appendix A Calculating Slaving Profits

Appendix B

William Davenport's Slaving Venture Profits

Bibliography 


\begin{abstract}
This thesis examines the business history of William Davenport (1725-1797), a Liverpool slave trading merchant from 1748 until 1786. Through an examination of a recently discovered collection of Davenport's business papers and personal letters, this thesis places Davenport in the context of Liverpool's development as a slaving port, and the growth of the town's slaving merchant community. It explains how Davenport became one of the largest slaving merchants of his generation, and one of the wealthiest Guinea merchants in Liverpool's history. To explain Davenport's rise the thesis focuses on how he managed his slaving company. It studies two distinct areas of the Guinea coast where he traded for slaves-Old Calabar and Cameroonand demonstrates how he cultivated merchant partners, and developed a supply chain of trading goods, to suit the unique conditions of both African markets. The thesis also explores Davenport's business profits by examining his returns from several different areas of investment, including the slave trade, the ivory trade and his speculation in financial securities. By building a composite picture of Davenport's diverse business concerns the thesis argues that the profits of the slave trade were crucial to his financial success. Davenport's enterprising expansion of the slave trade into the Cameroon in the 1750s was decisive in generating his slaving profits, and ultimately his wealth.
\end{abstract}




\section{Acknowledgements}

Thanks must first go to my supervisor Steve Behrendt for his invaluable advice and guidance without which this thesis would not have been completed. Thanks also to my fellow postgraduate students James Campbell, Malcolm Craig, Michael Devine, Craig Watterson, Sam Ritchie, Michael Gill and Karen Cheer, for providing their invaluable friendship and advice. I am also grateful to Victoria University for funding my studies through a scholarship, and the History Department for providing a comfortable and accommodating working environment. Special thanks go to my family and Stacey for their encouragement and support throughout my MA. 


\section{List of Tables and Figures}

\section{Tables}

Table 1 Table 1: Ten largest Liverpool slave trading merchants, trading c. $1740-1790$

Table 2 The Old Calabar and Cameroon slave trades, 1756-1785

Table 3 Captains' journeys to Manchester and London to purchase textiles for Old Calabar, Liverpool slaver Dalrymple, 1768-1777

Table $4 \quad$ Liverpool slaving ship Badger's barter transactions at Cameroon, 1777

Table 5 William Davenport's merchant partners in the Cameroon region, 1765-1785

Table 6 Slaving voyages not included in Richardson's venture profit calculations

Table 7 Profits on Davenport's slaving ventures by period, 1757-1785

Table 8 Profits on Davenport's slaving ventures by region, 1757-1774 88

Table 9 William Davenport's slaving vessels, 1779-1783 90

Table $10 \quad$ Badger and Hawke to Cameroon, 1776 And 1779

Table 11 William Davenport's ivory profits January 1763- January 178597

Table 12 Estimated profits on Davenport's privateering ventures, 1779-1781 101

Table 13 Estimated profits on Davenport's African produce ventures，1780-1782 103

Table 14 Table 14: William Davenport's business investments and profits, 106 1757-1797

Table A1 David Richardson's “discounted” venture profits formula 113

Table A2 Residual values of the King of Prussia's hull, 1767-1774 115

Table A3 "The Ship Dobson's 3rd Voyage" 116

Table A4 Undiscounted venture profits formula 118

\section{Figures}

Figure $1 \quad$ Pounds sterling invested by William Davenport in 26

Figure 2 William Davenport's trading pattern by African region, 1748-1785 49 (By $£$ invested)

Figure 3 Trading goods shipped to Old Calabar and Cameroon, 1757-1792 (By percentage Of $£$ Value)

Figure 4 Metals shipped to Old Calabar and Cameroon, 1750-1783 


\section{Introduction}

In October 2000 a remarkable set of merchant papers appeared on the BBC's Antiques Roadshow program. A farm worker had discovered them in a Cheshire barn during the 1950s, whilst clearing the structure. Thankfully he recognised that the papers may have historical significance and prevented them from being burned as useless. Comprising twelve leather bound volumes and thirteen bundles of loose letters, the collection contained a wealth of information on the management of a Liverpool slave trading firm, information that, as the appraiser commented, "one dreams of finding". The BBC's antiques expert identified the papers as those of William Davenport, an eighteenth century Liverpool merchant, and conservatively valued them at $£ 5,000$. $^{2}$

When historians of Liverpool or the slave trade learned about the "Davenport Papers," they knew that this collection supplemented another set of papers that had been discovered earlier. In 1951 a substantial collection of William Davenport's trading accounts came to light in the Davies Davenport collection at Manchester's John Rylands library. ${ }^{3}$ The papers comprised accounts ledgers, a letter book and, most importantly, detailed trading accounts for nearly eighty slave trading voyages made from Liverpool to Africa between 1761 and 1784. ${ }^{4}$ This first set of Davenport's papers was the most detailed set of documents relating to Liverpool's slave trade ever found. No other Liverpool merchant accounts compare in size and detail with this collection: the papers of William Earle, a close associate of Davenport and another key slave trading merchant, contain no voyage accounts and no accounts ledgers; the Tarleton, David Tuohy, Case \& Southwark, and Thomas Leyland papers, are much

\footnotetext{
${ }^{1}$ Anonymous, "Antiques Roadshow UK: Broadcast Highlights, Biddulph", PBS, 2009, available from http://www.pbs.org/wgbh/antiquesuk/highlights/113.html.

${ }^{2}$ Ibid.

${ }^{3}$ The papers were originally housed in the Davies Davenport section of the Bromley Davenport Muniments, John Rylands Library, Manchester University, England. They were subsequently moved to the Raymond Richards Collection at Keele University Library, Staffordshire, England, and are also available on microfilm from Microform Academic Publishing.

${ }^{4}$ In addition to the ship accounts, the collection contains the following accounts ledgers: "Waste Book 1745-1766", "Account Book for Beads and Cowries 1766-1770", "Letter and Bill Book 1747-1761", "Register of Bills of Exchange 1769-1787", "Entry Book 1760-1775", "Ledger Book 1763-1775", "Ledger Book 1788-1797". The "Old" Davenport papers will be referenced using the abbreviation ODAV throughout this thesis.
} 
smaller in scope and contain only thirteen voyages accounts. ${ }^{5}$ The Davenport papers exceed in size all of these other Liverpool merchant papers put together.

William Davenport's career spanned thirty-eight years of the Liverpool slave trade from 1748 until 1786, during which time he invested $£ 125,000$ in the trade and owned shares in 163 individual ventures. In addition, Davenport supplied articles to slaving vessels including beads, iron goods and ships provisions. Davenport's large investment in the slave trade, coupled with his pioneering expansion of the trade east of Old Calabar in the 1750s, made him one of the most important Liverpool slave trading merchants of his generation. Appreciating Davenport's significance to the Guinea trade, the Merseyside Maritime Museum purchased the newly discovered papers for $£ 25,000$ in 2006 , making them available to the public shortly thereafter. ${ }^{6}$

Historians have used the "Old" Davenport papers, those held first at the John Rylands Library, as the basis for a number of articles on William Davenport and the Liverpool slave trade. In 1951 Bradbury Parkinson published the first study of the Davenport papers, albeit a limited one, when he discussed the method of accounting used in the records, and contextualised them with other eighteenth century merchant accounts. ${ }^{7}$ Given Parkinson's interest in the history of accounting, he spent little time investigating the relevance of the papers to the slave trade. Two years later Parkinson, together with Francis Hyde and Sheila Mariner, used the Davenport papers to examine the organisation of the Liverpool slave trade in their 1953 article 'The Nature and Profitability of the Liverpool Slave Trade'. ${ }^{8}$ Their paper presented an overview of Davenport's trading career, analysed a limited number of his slaving voyages in detail, and used the papers to detail how the Liverpool slave trade operated, concluding with an assessment of its profitability.

After Parkinson's initial studies, the Davenport papers were ignored until the mid 1970s, when economic historians renewed their interest in the collection. In 1975, Roger Anstey re-appraised the Davenport papers in conjunction with other extant merchant papers to determine an industry wide level of profits for the British slave

\footnotetext{
${ }^{5}$ The Earle papers are held in the Merseyside Maritime Museum (MMM), Liverpool, England. The other four sets of merchant papers are housed in the Liverpool Record Office (LRO), Liverpool, England.

${ }^{6}$ Anonymous, "Slave Trade Revealed in Historic Papers", BBC News, 2001, available from http://news.bbc.co.uk/2/hi/uk_news/england/1718422.stm

${ }^{7}$ Bradbury B. Parkinson, "A Slaver's Accounts", Accounting Research, vol. 2, (Apr. 1951), pp.144-150

${ }^{8}$ Francis Edwin Hyde, Bradbury B. Parkinson, and Sheila Mariner, "The Nature and Profitability of the Liverpool Slave Trade", The Economic History Review, vol. 5, no. 3, (1953), pp.368-377
} 
trade. Using data extrapolated from the merchant papers, Anstey established a method of calculating slaving profits that included deductions for credit transactions, the value of the slave ship, and the purchase of African produce. After accounting for these various charges, Anstey arrived at an average industry wide profit figure of 9.5 percent, and concluded that the British slave trade was not "profitable beyond the dreams of avarice." $"$

A year later, David Richardson advanced the study of slaving profits in his significant paper "Profits in the Liverpool Slave Trade: the accounts of William Davenport, 1757-1784". ${ }^{10}$ In contrast to Anstey's calculation of industry wide slaving profits, Richardson focused solely on the seventy-four slaving voyages documented in the Davenport papers. He compared the cost of the ship and cargo to the returns from slave sales, and discounted for credit the outlays and returns, to give an adjusted venture profit for each of Davenport's voyages. Based upon his calculations, Richardson argued that Davenport's average profits from the slave trade were just 10.5 percent, and also "hard earned", indicating, like Anstey, that the Liverpool slave trade was not an automatic road to riches.

In 1977 B.L Anderson used the bill book, a ledger recording Davenport's credit transactions from 1769-1786, to study the bills of exchange system used in the Liverpool slave trade. Anderson traced Davenport's sizeable web of customers, suppliers and factors throughout the Atlantic world and assessed Davenport's career by charting the returns he received from slave sales. Based upon Davenport's slave trading, Anderson concluded that:

the ultimate yardstick of success or failure in the slave trade was not so much achievement of a healthy rate of return to the individual expedition but the ability of the trader to realise his net profit quickly and easily on a regular basis ${ }^{11}$

\footnotetext{
${ }^{9}$ Roger Anstey, The Atlantic Slave Trade and British Abolition 1760-1810, (London: 1975), p.46

${ }^{10}$ David Richardson, "Profits in the Liverpool Slave Trade: The Accounts of William Davenport," in Liverpool, the African Slave Trade, and Abolition, ed. Roger Anstey and Paul Hair, (Liverpool: 1979), pp.60-90; David Richardson also authored "A Brief Introduction to the Microfilm Edition of the William Davenport Papers," British Online Archives, 1998, available from http://www.britishonlinearchives.co.uk/9781851171767.php; and the Oxford Dictionary of National Biography entry: "Davenport, William (1725-1797)", Oxford Dictionary of National Biography, 2004, available from http://www.oxforddnb.com/view/article/55685

${ }^{11}$ B.L. Anderson, "The Lancashire Bill System and Its Liverpool Practitioners: The Case of a Slave Merchant," in Trade and Transport: Essays in Economic History in Honour of T.S. Willan, ed. W.H. Chaloner and B.M. Ratcliffe, (Manchester: 1977), p.80
} 
For a merchant such as Davenport, then, liquidity and the creditworthiness of his debtors were key considerations in his slaving business, not the achievement of large profit margins.

Anstey, Richardson and Anderson's research into the Davenport papers reinvigorated a debate on the slave trade's profitability that began two hundred years ago. Even when the British slave trade operated legally, by sanction of Parliament, its profits had come under scrutiny from some MPs and pamphleteers. ${ }^{12}$ Caught up in the charged question of abolition, these eighteenth century commentators offered a variety of opinions. Some, like abolitionist Thomas Clarkson, suggested that the trade was, at best, marginally profitable, and more often than not a losing business. ${ }^{13}$ John Newton, an abolitionist and former slaving captain, described slaving profits as "a lottery." 14 Conversely, supporter of the slave trade James Wallace, author of a 1795 history of Liverpool, and former slaving surgeon Elliot Arthy, claimed that the profits from the Africa trade were not only large, but also crucially important to Liverpool's growth. Wallace argued, for example, that thanks to the slave trade, a

great annual return of wealth, may be said to pervade the whole town, increasing the fortunes of the principal adventurers, and contributing to the support of the majority of the inhabitants; ${ }^{15}$

Using industry wide estimates, Arthy argued that each slaving vessel made a clear profit to her owners of $£ 3,850$, and that the "repairing and outfitting" of Liverpool's slaving fleet employed twenty-seven different groups of tradesmen, six thousand seamen, and numerous manufacturers. In short, Arthy summarised that the slave trade's "immense quantum of business" has "doubtless, been the principal means of bringing [Liverpool] to its present and flourishing state". ${ }^{16}$

Nineteenth century historians agreed with Wallace and Arthy's analyses that slaving enriched individual merchants and Liverpool. Liverpool historian Richard Brooke wrote in 1853 that a "large number of Liverpool persons... made their

\footnotetext{
12 "Estimates of Profits under Regulated Trade" in Elizabeth Donnan, Documents Illustrative of the History of the Slave Trade to America: The Eighteenth Century, 4 vols., vol. 2, (Buffalo, NY: 2002) pp 578-581; See also the testimony before Parliament of slaving merchants James Jones (PP 68 (1789), p.44), John Tarleton (PP 68 (1789), pp.47-48), and Robert Norris (PP 68 (1789), p.8).

${ }^{13}$ Thomas Clarkson, An Essay on the Impolicy of the African Slave Trade : In Two Parts, 2nd ed., (London: 1788), pp.27-32

${ }^{14}$ Testimony of John Newton (PP 73 (1790), p.145)

${ }_{15}$ James James Wallace, A General and Descriptive History of the Ancient and Present State, of the Town of Liverpool, (Liverpool: 1795), p.229

${ }^{16}$ Elliot Arthy, Introductory Observations in Favour of the African Slave Trade, (Liverpool: 1804), pp. $28-50$
} 
fortunes in the African slave trade, and some of them acquired by that odious traffic considerable wealth." 17 At the end of the century, Gomer Williams and "A Genuine Dicky Sam" both quoted Wallace's profitability calculations verbatim in their respective accounts of the slave trade. ${ }^{18}$ Williams also attempted to build on Wallace's claims by analyzing the accounts of six slaving voyages, five of them financed by Liverpool mayor, banker and millionaire Thomas Leyland. ${ }^{19}$ After extrapolating the data from the accounts, Williams found that each vessel made approximately 80 percent profits. ${ }^{20} \mathrm{He}$ ended his analysis with Elliot Arthy's industry wide profits, data that clearly showed a "handsome profit" to Liverpool's slaving merchants.

The contention that slaving profits were both large and crucial to Liverpool's development formed a central idea in Eric Williams' influential work Capitalism and Slavery published in 1944. Using individual voyage accounts, Williams posited that voyage "profits of 100 percent were not uncommon in Liverpool, and one voyage netted a clear profit of at least 300 percent." ${ }^{, 21}$ Williams also used James Wallace's data to argue that industry wide profits sustained the growth of Liverpool itself: "The story of the increase in the slave trade is mainly the story of the rise of Liverpool." 22 Thus, 150 years after Wallace first published his history, his remained the orthodox view: that the slave trade had been a lucrative commerce, and one that had been the backbone of Liverpool's eighteenth century prosperity.

The research in the 1970s on the Davenport papers argued that the slave trade was a marginally profitable and highly volatile business - contrary to Wallace (1795) and Williams (1944) — did not remain uncontested. Complaining in 1981 that the "pendulum of scholarship has swung too far towards the position that the profits from slaving were small."23 Joseph Inikori attempted to redress the balance and contend

\footnotetext{
${ }^{17}$ Richard Brooke, Liverpool as It Was During the Last Quarter of the Eighteenth Century, 1775 to 1800, (Liverpool: 1853), p.236

${ }^{18}$ Anon., Liverpool and Slavery: An Historical Account of the Liverpool-African Slave Trade. Was It the Cause of the Prosperity of the Town? By a Genuine Dicky Sam, (Liverpool: 1884), pp.100-112

${ }^{19}$ Gomer Williams, History of the Liverpool Privateers and Letters of Marque : With an Account of the Liverpool Slave Trade, 1744-1812, (Liverpool: 1897), pp.594-608

${ }^{20}$ In 1931, Dumbell showed that Williams had made some serious errors in his interpretation of the accounts, the result of which was an overstatement of profits by 50 percent (Stanley Dumbell, "The Profits of the Guinea Trade", Economic History Supplement to Economic Journal, vol. 2, (1931), pp.254-257).

${ }^{21}$ Eric Williams, Capitalism and Slavery, (London: 1989), p.36

${ }^{22}$ Ibid., p.34

${ }^{23}$ J.E. Inikori, "Market Structure and the Profits of the British African Trade in the Late Eighteenth Century", The Journal of Economic History, vol. 41, (Dec. 1981), p.745
} 
once again that most slaving merchants earned large profits. Using Wallace's history as his starting point, a work Inikori complained had been "completely neglected by modern writers", Inikori argued that the Liverpool slave trade was highly competitive and, as a result, concentrated in the hands of less than a dozen rich merchant houses. ${ }^{24}$ These firms, Inikori stressed, possessed a comparative advantage in the slave trade and hence they managed to accrue exceptionally high profits.

Turning to the Davenport papers, Inikori questioned Richardson's methodology, specifically his use of discounted venture profits. ${ }^{25}$ Taking no account of credit transactions, Inikori suggested that Davenport received a much higher 17.9 percent return from his slaving ventures, supporting his argument that the Liverpool slave trade was a highly lucrative business for its large merchant investors. ${ }^{26}$ Richardson, supported by Anderson, debated the profitability question with Inikori in a series of rejoinders and rebuttals within The Journal of Economic History. ${ }^{27}$ Neither scholar managed to decisively establish their calculations as definitive, and hence the question of the Liverpool slave trade's profitability continues to be a source of controversy.

Interpretations of slaving profits remain controversial because the slave trade's profitability is an important and politically charged question. If, as Wallace, Williams and Inikori suggested, the Liverpool slave trade was highly profitable, then it would follow that these profits were channelled into, and fuelled the growth of Liverpool. If on the other hand the trade's profits were marginal and broadly comparable to other businesses, as Anstey, Richardson, and Anderson suggested, then the slave trade would be just one of several sources of investment for the town. These considerations are of interest beyond academic history. Modern reparations movements are keenly aware of the need to trace the proceeds of the slave trade and assess slavery's impact on the growth of Britain's ports and industries. In this way activists seek to quantify

\footnotetext{
${ }^{24}$ Ibid., p.749

${ }^{25}$ Ibid., pp.767-768

${ }^{26}$ Ibid., pp.769-773

${ }^{27}$ See B.L. Anderson and David Richardson, "Market Structure and Profits of the British African Trade in the Late Eighteenth Century: A Comment", The Journal of Economic History, vol. 43, no. 3, (Sep. 1983), pp.713-721; J.E. Inikori, "Market Structure and the Profits of the British African Trade in the Late Eighteenth Century: A Rejoinder", The Journal of Economic History, vol. 43, no. 3, (Sep. 1983), pp.723-728; B.L. Anderson and David Richardson, "Market Structure and Profits of the British African Trade in the Late Eighteenth Century: A Rejoinder Rebutted", The Journal of Economic History, vol. 45, no. 3, (Sep. 1983), pp.705-707; J.E. Inikori, "Market Structure and Profits: A Further Rejoinder", The Journal of Economic History, vol. 45, no. 3, (Sep. 1985), pp.708-711.
} 
the financial gains of the slave trade, and make reparations claims upon the individual governments, companies and towns to whom these benefits accrued.

Jane Longmore and David Pope's 2007 studies demonstrate the difficulty in tracing the profits generated by the slave trade to the development of Liverpool and north western England. Longmore sought to investigate the "cultural, physical and economic impact of the slave trade on late eighteenth century Liverpool" by tracing the investments of slaving merchants in the port's commercial and financial infrastructure in her paper "Cemented by the Blood of a Negro?: The Impact of the Slave Trade on Eighteenth-Century Liverpool." 28 In the same edited collection, Liverpool and Transatlantic Slavery, David Pope explored Liverpool's leading slave traders' investments in estates and properties around Merseyside, and their attempts to better themselves through marriage. As part of his study, Pope examined the wills of 178 leading slaving merchants to gauge the earnings made by Liverpool's Africa men. ${ }^{29}$ Pope and Longmore established that Liverpool's Guinea merchants invested heavily in the town and clearly possessed a great deal of property, but both studies also attached the same caveat: without looking at the merchant's entire investment portfolios one cannot attribute their gains solely to the slave trade.

There have been numerous histories of individual Liverpool slaving merchants to date, but none have been able to quantify their diverse business concerns. Historians have studied, for example, Sparling \& Bolden, Foster Cunliffe \& Sons, John Earle and his family, John Bolton, Robert Bostock and, of course William Davenport, in addition to a number of other individual merchants and slaving captains. ${ }^{30}$ Moreover, histories have been produced of industries in which slaving

\footnotetext{
${ }^{28}$ Jane Longmore, "'Cemented by the Blood of a Negro?' the Impact of the Slave Trade on Eighteenth Century Liverpool," in Liverpool and Transatlantic Slavery, ed. David Richardson, Suzanne Schwarz, and Anthony Tibbles, (Liverpool: 2007), p.227

${ }^{29}$ David Pope, "The Wealth and Social Aspirations of Liverpool's Slave Merchants of the Second Half of the Eighteenth Century," in Liverpool and Transatlantic Slavery, ed. David Richardson, Suzanne Schwarz, and Anthony Tibbles, (Liverpool: 2007), pp.208-215

${ }^{30}$ M.M. Schofield, "The Virginia Trade of the Firm of Sparling and Bolden, of Liverpool 1788-99", Transactions of the Historic Society of Lancashire and Cheshire, vol. 116, (1969), pp.117-165; John W. Tyler, "Foster Cunliffe and Sons: Liverpool Merchants in the Maryland Tobacco Trade, 17381765", Maryland Historical Magazine, vol. 73, no. 3, (Sept. 1978), pp.117-165; Dawn Littler, "The Earle Collection: Records of a Liverpool Family of Merchants and Shipowners", Transactions of the Historic Society of Lancashire and Cheshire, vol. 146, (1996), pp.93-106; Godfrey W. Matthews, "John Bolton: A Liverpool Merchant, 1756-1837", Transactions of the Historic Society of Lancashire and Cheshire, vol. 93, (1941), pp.98-115; Denise M. Jones, "The Business Organisation of the Liverpool Slave Trade in the Eighteenth Century: A Case Study of Robert Bostock" (MA, University of Liverpool, 2006)
} 
merchants invested in such as the coal, earthenware, banking and salt trades. ${ }^{31}$ We do not know, however, the level of investment or the returns received from these trades. Nor do we know how the profits from these trades compare to those from the slave trade.

The main difficulty in painting a full picture of a merchant's business concerns has been a lack of sources. Few merchant papers remain, and those that do are all far from complete. The Old Davenport papers, discovered in the 1950s, are no exception. The papers only contain one set of letters from Davenport himself, most of which were letters of instructions to slaving captains and West Indian merchants detailing how cargoes of slaves should be sold, 1748-1759. ${ }^{32}$ The format of these letters changes little over time, and hence they contain few insights into Davenport's decision making, or the financial performance of his firm. Moreover, the vast majority of the ship accounts and ledgers within the Old Davenport papers concern the period 1765-1775, an important decade for Davenport but only a quarter of his thirty-eight years trading as a merchant. Commenting on his detailed research into the Davenport papers, David Richardson noted that whilst the "range of records that have survived relating to Davenport's business activities is remarkable and far fuller than that for any other eighteenth century British slave trader"33 the records "concerning Davenport's commercial activities other than slave-trading is on the whole comparatively slight." ${ }^{34}$ Consequently historians researching Davenport's career have had to work from a substantial but far from complete collection.

The "New" Davenport papers, discovered in 2000 and made available to researchers in 2006, fill in many of the blanks in William Davenport's career. One of the twelve bound volumes is the "Ivory Book" detailing Davenport's ivory trading for

\footnotetext{
${ }^{31}$ T.C. Barker, "Lancashire Coal, Cheshire Salt and the Rise of Liverpool", Transactions of the Historic Society of Lancashire and Cheshire, vol. 103, (Feb 1951), pp.83-101; T.C. Barker and J.R. Harris, Merseyside Town in the Industrial Revolution: St. Helens, (London: 1959); Peter Hyland, The Herculaneum Pottery: Liverpool's Forgotten History, (Liverpool: 2005); John Hughes, Liverpool Banks and Bankers, 1760-1837 : A History of the Circumstances Which Gave Rise to the Industry, and of the Men Who Founded and Developed It, (Liverpool: 1906); B. L. Anderson, "Financial Institutions and the Capital Market on Merseyside in the Eighteenth and Nineteenth Centuries," in Commerce, Industry and Transport : Studies in Economic Change on Merseyside, ed. B. L. Anderson and P. J. M. Stoney, (Liverpool: 1983), pp.26-53

${ }^{32}$ Letter and Bill Book 1747-1761, Liverpool, ODAV

${ }^{33}$ David Richardson, "A Brief Introduction to the Microfilm Edition of the William Davenport Papers," British Online Archive, 1998, available from http://www.britishonlinearchives.co.uk/9781851171767.php, p.3

${ }^{34}$ Richardson, "The Accounts of William Davenport," p.63
} 
the period 1763-1785. ${ }^{35}$ Davenport carried on a substantial trade in ivory throughout his career, and the Ivory Book shows the exact size, weight and price, of the tusks he bought and sold. The Ivory Book also contains copies of Davenport's outgoing letters for the period 1779-1783. These letters are far more detailed than those found in the Old papers and shed light on Davenport's financial performance throughout the period. In particular, the letters discuss numerous slaving voyages made during the American War, a crucially important phase of Davenport's career, and one in which he earned exceptional profits and suffered massive losses from his ventures.

Complementing the letters within the Ivory Book are thirteen bundles of correspondence sent and received by Davenport in the period 1767-1794, but particularly concentrated for the years $1774-1784 .^{36}$ The letters cover a variety of subjects including Davenport's bead trading, his administration of a prominent London banker's estate, and the collection of debts from West Indian factors during and after the American War. ${ }^{37}$ Moreover, eight bundles of the letters concern specific slaving vessels and detail the trading conditions on the African coast, an area only scantily covered by the Old Davenport papers. ${ }^{38}$ Trading accounts detailing six slaving voyages made during the American War add to the letters on Davenport's individual ventures. $^{39}$

In addition to the Ivory Book, letters, and ship accounts, the New Davenport papers contain numerous other ledgers that are crucial to a reconstruction of Davenport's business history. Of most use are a personal cash book for 1747-1760, a cash book for Davenport's bead company, 1766-1776, a waste book (a memorandum ledger into which sales are entered), 1766-1780, and an account book detailing transactions with other merchants. ${ }^{40}$ The waste book is particularly useful as it is

\footnotetext{
${ }^{35}$ Ivory Book 1763-1785, Liverpool, D/DAV/1

${ }^{36}$ The bundles of letters were not given titles or references by Davenport. As a result the MMM assigned a system of referencing using the suffix D/DAV/. This system be used throughout this thesis.

${ }^{37}$ Letters Regarding Bead Business 1767-1768, Liverpool, D/DAV/5; Letters to William Davenport \& Company Regarding Beads 1768-1777, Liverpool, D/DAV/6; James Morson, Vance Caldwell \& Vance 1775-1781, Liverpool, D/DAV/8; Letters, Bills etc Voyage of Barque Prince George from Dominica 1777-1778, Liverpool, D/DAV/12; John Robinson trustee of Vance's estate 1787, Liverpool, D/DAV/16; Estate of Thomas Wycliffe 1777-1782, Liverpool, D/DAV/18; Estate of Jos. Wimpey 1772-1793, Liverpool, D/DAV/19; Davenport Family 1794, Liverpool, D/DAV/20

${ }^{38}$ Badger's $3^{\text {rd }}$ Voyage 1774-1776, Liverpool, D/DAV/7; Paper's Ship new Badger's inward acco 1777, Liverpool, D/DAV/10; Hector's Voyages to Africa \& Dominica 1777, Liverpool, D/DAV/11; Essex's second voyage to Africa and the Caribbean 1783-1785, Liverpool, D/DAV/13

${ }^{39}$ Ship Accounts 1768-1787, Liverpool, D/DAV/2

${ }^{40}$ Personal Cash Book 1747-1760, Liverpool, D/DAV/2; Personal Ledger 1763-1772, Liverpool, D/DAV/2; Bead Cash Book 1766-1776, Liverpool, D/DAV/2; Waste Book 1766-1780, Liverpool, $\mathrm{D} / \mathrm{DAV} / 2$
} 
contiguous to an earlier waste book within the Old papers for the period 1745-1766. ${ }^{41}$ By combining the two books, a continuous run of transactions from 1745 to 1780 can be reconstructed, giving a detailed picture of Davenport's business concerns. The period not covered by the ledgers and waste books, 1780-1783, is covered by the letters contained in the Ivory Book, and the last years of Davenport's life, 1788-1797, are described in an account ledger, allowing us to see how Davenport spent his retirement. ${ }^{42}$ Thus, the "Old" and the "New" Davenport papers in combination provide an almost complete picture of the trading concerns and business practices of William Davenport.

Research performed for this thesis has uncovered additional manuscripts, further filling in the gaps in Davenport's career. The most important new document is Davenport's residuary settlement, a small book detailing the value of his estate upon his death in 1797, located within the Bromley Davenport Muniments (BDM) in the John Rylands Library, University of Manchester. ${ }^{43}$ To date, a difficulty when studying Davenport has been a lack of detail concerning the value of his estate. As a result, exact calculations of his ultimate gains from the slave trade have been impossible. Both Richardson and Inikori suggested that Davenport made little from the slave trade. Richardson stated, for example, that "the evidence of [Davenport's] own accounts and papers suggests that, for all his dedication and enterprise in the pursuit of the slave trade, he was not one of the fortunate few." 44 The discovery of Davenport's residuary settlement allows us to challenge this assumption, and contextualize him with his contemporaries using Pope's extensive research on other slaving merchant's wills. The BDM also contains a number of letters from Davenport to his family in the early years of his merchant career which help to establish why he chose to move to Liverpool, and what his apprenticeship entailed. Taken together, the manuscripts contained in the John Rylands Library helps to fill in blanks at both the beginning and end of William Davenport's life.

Finally, Voyages: The Trans-Atlantic Slave Trade Database documents all of Davenport's known slaving investments. Originally published in 1999 as a CD-ROM,

\footnotetext{
${ }^{41}$ Waste Book 1745-1766, Liverpool, ODAV

${ }^{42}$ Ledger Book 1788-1797, Liverpool, ODAV

${ }^{43}$ Residuary Settlement of William Davenport, Liverpool, c.1797, Box 19, Bromley-Davenport Muniments, John Rylands Library, Manchester Univeristy, England (hereafter BDM)

${ }^{44}$ Richardson, "Introduction to the Davenport Papers," p.6; Inikori also stated that "the history of the Liverpool slave trade does not know William Davenport as one of those who made fortunes from the trade." (Inikori, "Market Structure and the Profits ", p.770).
} 
and subsequently updated and released online in 2008, Voyages contains 34,940 documented slaving voyages, including 4,974 departing Liverpool. ${ }^{45}$ The database compiles these voyages from extant shipping records, newspapers, published and unpublished secondary sources, and private notes and collections. Voyages is particularly detailed for the British slave trade in the period 1750-1807, and includes virtually complete ship-owner data for Liverpool slaving vessels. Moreover, the database can produce graphs and tables to interpret ownership information, and changes in the volume and structure of the slave trade over time. As such it is the most complete guide to the Liverpool slave trade available today, allowing us to assemble, for the first time, Davenport's complete slaving investment pattern, and compare that pattern to other Liverpool slaving merchants.

This thesis will use the recently discovered New Davenport and Bromley Davenport Muniments, in combination with the Old Davenport papers and the Voyages Database, to examine the life and career of William Davenport, Liverpool slave trading merchant. It will provide the most complete picture to date of Davenport's biography, his place in the Liverpool merchant community, his business history and his ultimate success or failure in the slave trade.

Chapter one will sketch the biography of William Davenport and place him in the wider context of Liverpool's merchant community. Using the information available from the Bromley Davenport Muniments, we will consider Davenport's motive in migrating to Liverpool and his decision to enter the slave trade. We then establish Davenport's status in the slaving merchant community by examining his financial investment in the trade vis-à-vis both his contemporaries, and those merchants who succeeded him.

Chapter two will analyse how William Davenport managed his slave trading firm by focusing on his trade to Old Calabar and Cameroon, two slaving markets in the eastern Bight of Biafra. Using the detail in the Davenport papers, we will ascertain how the slave trade operated at both ports, paying particular attention to the differing consumption patterns of each market's African traders. We then will study the steps

\footnotetext{
${ }^{45}$ Available from www.slavevoyages.org. The Voyages dataset will be used throughout this thesis, and any slaving voyages mentioned will use the unique voyage identification number taken from the database, with the prefix "Voyages Database"
} 
Davenport took to overcome the two regions' differences by investigating his partnership formations and business strategies in Liverpool.

Chapter three will consider the controversial profitability question by comparing and contrasting Davenport's investments and profits from a number of different industries. We will begin by analysing how Davenport organised his firm to maximise his slaving profits. We then will assess Davenport's slave trading profits by calculating returns from 110 of his slaving voyages. In the final section, Davenport's slaving profits will be compared to his earnings from non-slaving investments allowing us, for the first time, to consider the investment portfolio of a Liverpool slaving merchant.

Finally, we will question whether Davenport's career is representative of Liverpool's wider merchant community. Can Davenport be considered an exemplar of a "typical" slaving merchant? If so can we consider Davenport's slaving profits and business model as indicative of Liverpool's entire slaving industry? Alternatively, was Davenport an exceptional character, completely unrepresentative of the Liverpool slaving merchant community? 


\section{Chapter One: William Davenport and the Liverpool Slaving Merchant Community}

William Davenport was born on 8 October 1725 into a gentry family established in Cheshire since the Norman conquest. Aged sixteen, Davenport apprenticed to Liverpool merchant William Whaley, with whom he served a seven year indenture, training in the grocery and Africa trades. At the end of his service in 1748, Davenport established himself as an independent merchant, and for the next forty years he specialised in the African slave trade, with the 1760s and 1770s marking the peak years of his career. After the American Revolutionary War, Davenport reduced his investments, finally retiring in 1786. He died eleven years later, a bachelor aged seventy-three, and bequeathed his fortune to his brother, nephew and niece.

William Davenport was one of Liverpool's most important slave trading merchants. Throughout his thirty-eight year career as a ship owner, he invested in 163 slaving ventures, more than any other merchant in the history of the Liverpool slave trade. These vessels carried nearly 40,000 Africans to the Americas, and involved a personal investment from Davenport of $£ 127,000$, equivalent to $£ 10$ million sterling today. ${ }^{1}$ Davenport's lengthy involvement in the slave trade, coupled with his substantial personal investment made him one of the largest and most ubiquitous slaving merchants of his day.

Focusing on Davenport's life and business career, this chapter will place William Davenport in the context of the rise of Liverpool and the growing size and wealth of the town's slaving merchant community. We will begin by charting the growth of Liverpool during the late seventeenth and early eighteenth centuries, showing how the town emerged as a slaving port. We then will chronicle Davenport's life and career, from his youth, to his apprenticeship and career as a slaving merchant, and then eventually to his retirement and death. Finally we will establish Davenport's place in the Liverpool slaving merchant community by considering his status compared to both his contemporaries and those merchants who succeeded him.

\footnotetext{
${ }^{1}$ Laurence H.Officer, "Purchasing Power of British Pounds from 1264 to Present," Measuring Worth, 2009, available from http://www.measuringworth.com/ppoweruk/
} 
Had William Davenport been born in 1625, rather than 1725, he would have not have chosen Liverpool as a place to make his fortune. In the early seventeenth century, Liverpool was a fishing hamlet nestled on the muddy banks of the Mersey and peopled by just 2,000 people. $^{2}$ The only advantage Liverpool possessed was its position "commodiously seated on the goodly river Mersey" giving it easy access to the Irish Sea. ${ }^{3}$ As a result, trade with Ireland, and to a lesser extent France, formed the backbone of Liverpool's early commerce. Liverpool's vessels freighted textiles, salt and manufactures abroad, in exchange for leather, grain, butter, wine and, most importantly, linen yarn - a crucial commodity for Lancashire's budding textile industry. ${ }^{4}$ However, this small amount of trade, carried out by just ten ships per month even as late as the 1660s, formed but a fraction of Britain's overseas commerce, with London's shipping dwarfing that of the "outport". Liverpool, then, was little more than a village for much of the seventeenth century.

The expansion of neighbouring Lancashire and Cheshire's industries in the 1670s spurred Liverpool's expansion beyond its humble beginnings. Cheshire had long been a centre for British salt production, and Liverpool merchants had exported the commodity to the Newfoundland fisheries as early as $1600 .^{5}$ In 1670 , the discovery of rock salt at nearby Marbury created a surge in the industry. ${ }^{6}$ Liverpool offered the ideal outlet for Cheshire's salt to be processed and then exported to the rest of Britain and her colonies thanks to its proximity to the salt fields and to Ireland. As a result, Liverpool's salt exports increased ten fold between 1670 and $1700 .^{7}$ As salt boilers demanded fuel for their fires, an expansion in the Lancashire coal industry

\footnotetext{
2 Brian Refford, "The Bonds of Trade: Liverpool Slave Traders, 1695-1775" (PhD, Lehigh University, 2005), p.10; William Enfield, An Essay Towards the History of Leverpool, 2nd ed., (London: 1774), pp.12-14

${ }^{3}$ Quoted in Jenny Kermode, Janet Hollinshead, and Malcolm Gratton, "Small Beginnings: Liverpool 1207-1680," in Liverpool 800 : Culture, Character and History, ed. John Belchem, (Liverpool: 2006), p.109

${ }^{4}$ H.R. Fox Bourne, English Merchants: Memoirs in Illustration of the Progress of British Commerce, 2 vols., vol. 2, (London: 1866), p.45; James A. Picton, Memorials of Liverpool, Historical and

Topographical, Including a History of the Dock Estate, 2 vols., vol. 2, (London: 1873), p.4

5 Thomas Baines, History of the Commerce and Town of Liverpool and of the Rise of Manufacturing Industry in the Adjoining Counties, (London: 1852), p.9

${ }^{6}$ Barker, "Lancashire Coal, Cheshire Salt and the Rise of Liverpool", p.84

${ }^{7}$ Salt exports rose from 26,000 bushels in the period 1670-79, to 30,000 bushels in 1680-88 and then to 239,000 bushels in 1689-96 (Paul Clemens, "The Rise of Liverpool, 1665-1750", The Economic History Review, vol. 29, no. 2, (May 1976), p.212).
} 
also occurred, so that by the late seventeenth century Liverpool exported large quantities of coal and salt throughout Britain and northern Europe. ${ }^{8}$

The 1670s also witnessed Liverpool's shift into the burgeoning Atlantic plantation markets. Taking advantage of an increasing demand for sugar, coupled with a rapidly falling price, Liverpool traders dispatched ships to the West Indies, principally to Barbados, to freight sugar back to markets in northern England. Crucial to this development was Liverpool's long standing ties to Ireland because, as Paul Clemens has shown, in the late seventeenth century "Ireland's human and agricultural resources proved increasingly critical to West Indian planters." "2iverpool merchants took advantage of these resources by creating a "triangular pattern" whereby their vessels exchanged Liverpool's traditional exports—salt, coal and manufactures-in Ireland for produce and indentured servants, and then carried them to the West Indies to be traded for sugar. ${ }^{10}$ Using this same triangular route, Liverpool also shifted into the Virginia tobacco trade, transporting indentured servants to frontier lands in the Middle Colonies, and returning with lower grade, but still marketable, leaf tobacco. ${ }^{11}$

Liverpool's hasty transformation into an international trading port created a shipping boom. In 1672, 2,600 tons were registered to the port, almost all of which engaged in the Irish trade. Thirty years later, that figure had tripled to 8,600 tons, with many of those vessels being larger brigs or snows destined for the Atlantic seaboard. ${ }^{12}$ The Liverpool town council highlighted the growth of Liverpool and her shipping in a 1699 petition to the King, requesting that the town be designated a separate parish from neighbouring Prescott: "Liverpool was formerly a fishing village... but has now the third part of the trade of England, and pays upwards of 50,0001. per annum to the King." 13

To accommodate this expansion in shipping Liverpool's common council ambitiously voted in 1709 for the construction of the world's first commercial wet dock. For the relatively small port town of Liverpool to finance the first wet dock ahead of London, Bristol, and the other bustling ports of Europe, required, as

\footnotetext{
${ }^{8}$ Ibid., p. 217

${ }^{9}$ Ibid., p. 214

${ }^{10}$ Kermode, Hollinshead, and Gratton, "Liverpool 1207-1680," p.86; Francis Edwin Hyde, Liverpool and the Mersey: An Economic History of a Port, 1700-1970, (Newton Abbot: 1971), p.12

${ }^{11}$ Clemens, "Rise of Liverpool", pp.214-215

12 Jane Longmore, "Civic Liverpool: 1680-1800," in Liverpool 800 : Culture, Character and History, ed. John Belchem, (Liverpool: 2006), p116; a snow or "snauw" is a large two-masted sailing vessel.

${ }^{13}$ Quoted in Bourne, English Merchants, p.46
} 
Longmore rightly argues, "Entrepreneurial flair, embryonic civic pride, political skill, and self-interest." ${ }^{\prime 14}$ The dock scheme's ambition matched the scale of proposed work: the wet dock comprised a large self contained water filled concrete basin, measuring 195 yards by 95 yards, constructed near the water so as to allow an outlet to the sea. The project took seven years and nearly $£ 50,000$ to complete, a substantial sum mortgaged on Liverpool's common property. ${ }^{15}$ The town council's gamble paid off when a new district of streets, warehouses and industry sprung up around the Old Dock site, transforming the formerly water logged area into a flourishing commercial district, and marking Liverpool as an ambitious and forward looking city. ${ }^{16}$

Liverpool merchants looked to the African slave trade to further expand the town's horizons. In 1699 John Earle and William Clayton financed Liverpool's first Guineamen, the ship Union. ${ }^{17}$ At least seven further vessels plied the Guinea trade in 1700-1702 before the outbreak of the War of Spanish Succession (1702-1713). ${ }^{18}$ However, competition hindered Liverpool's burgeoning African trade. London merchants maintained control over the seventeenth century slave trade thanks its government monopoly under the Royal Africa Company and a series of forts in the Gambia River, the Sierra Leone region, along the Gold Coast, and at Ouidah (Whydah). Once parliament opened the Africa trade to private enterprise in 1698, Bristol merchants pushed aggressively into parts of the Guinea coast where the Company did not maintain forts, such as the Bight of Biafra. ${ }^{19}$

Lacking commercial networks on the African coast, Liverpool's entry into the slave trade began slowly: just nine vessels are known to have sailed to the Guinea coast in the first ten years of the eighteenth century. By dispatching ships to the less

\footnotetext{
${ }^{14}$ Longmore, "Civic Liverpool: 1680-1800," p.121

${ }^{15}$ Brooke, Liverpool as It Was, p.97; The cost of the works included $£ 30,000$ for the construction of the dock itself, and $£ 20,000$ "for the building of warehouses offices, commercial buildings and dock appurtenances" (Hyde, Liverpool and the Mersey, p.14)

${ }^{16}$ Hyde notes that this "small building boom" engrossed private capital "variously estimated at between $£ 100,000$, and $£ 120,000 . ”$ (Ibid., p.14)

${ }^{17}$ There may have been two prior voyages before the Union (Voyages Database 24275) in 1696. However, the names of the ships and their masters are unknown (Voyages Database 21236 and 21237). ${ }^{18}$ There were three documented voyages in 1700 (Voyages Database 15122, 24240 and 25242), three in 1701 (Voyages Database 15124, 15123 and 20237), and only one in 1702 (Voyages Database 15110). There appears to have then been a lull in the Liverpool slave trade until 1710, after which time the volume of slaving vessels substantially increased year on year.

${ }^{19}$ Parliament ended the Royal African Company's monopoly in 1698 by opening up the slave trade to "separate traders" - merchants unaffiliated to the company - on the proviso that they paid a ten percent duty on exports to Africa. After a 1709 Board of Trade enquiry found that the separate traders had exceeded the RAC's volume of slaves exported, the ten percent tax was allowed to lapse creating, in effect, a free trade (James A. Rawley and Stephen D. Behrendt, The Transatlantic Slave Trade: A History, Rev. ed., (Lincoln: 2005), pp.140-141).
} 
frequented, and hence lower cost, areas of the African coast, however, Liverpool's merchants rapidly expanded the town's share of the slave trade. In the 1720s fortytwo slaving voyages sailed for Africa, or seven percent of the national total. In the 1730s Liverpool merchants outfitted 197 voyages, twenty-seven percent of Britain's Africa ventures. ${ }^{20}$ War with France and Spain in the War of the Austrian Succession (1739-1748) enabled Liverpool to gain ascendancy. The war proved a disaster for London and Bristol slaving merchants as their vessels left port into the privateer infested English Channel. Liverpool vessels, by contrast, enjoyed a relatively safe passage north of Ireland. ${ }^{21}$ As a result, Liverpool's share of the African slave trade rose from 8,000 captives shipped in 1740, to 11,000 in 1748, whilst Bristol's declined from 10,000 to 8,000 in the same period. London's fall was even more dramatic: the port's merchants carried off 3,400 African captives at the beginning of the war, and just 1,200 at its conclusion. ${ }^{22}$ As Rawley noted, 1744 marked "the pivotal year... when the number of Liverpool ships clearing for Africa exceeded the number from Bristol, and every year thereafter Liverpool outdistanced Bristol., ${ }^{23}$

In just seventy years from 1670 until 1740, then, Liverpool's merchants had expanded the port's commercial trade throughout the globe, and stood poised to aggressively overtake Bristol and London as the pre-eminent British slave trading port. Such was the rapid expansion of trade that in the period 1702-1744 Liverpool's tonnage tripled to 20,900 tons. $^{24}$ The town's booming trading fortunes affected a physical transformation. Even at the turn of the eighteenth century the town's buildings had been crude, two storey stone structures with rough shingle roofs and dim windows, squeezed into a cramped footprint of just twenty-four streets by the Pool, an inlet of water running up from the river Mersey. Having only been declared a separate parish in 1699, Liverpool could count only one church-St Nicholas'-and the other public buildings looked unsophisticated and ramshackle. ${ }^{25}$ Yet by the middle of the eighteenth century, the town could count no less than 222 "streets, lanes and

\footnotetext{
${ }^{20}$ Kenneth Morgan, "Liverpool's Dominance in the British Slave Trade, 1740-1807," in Liverpool and Transatlantic Slavery, ed. David Richardson, Suzanne Schwarz, and Anthony Tibbles, (Liverpool: 2007), p.14

${ }^{21}$ Ibid., p. 20

${ }^{22}$ Slave volumes are taken from the Voyages Database

${ }^{23}$ Rawley and Behrendt, Transatlantic Slave Trade, p.177

${ }^{24}$ Hyde, Liverpool and the Mersey, p.235-36

${ }^{25}$ As Kermode et al point out, Liverpool's "principal buildings" in the late seventeenth and early eighteenth century were in a poor state of repair: "The castle was ruined, the More Old Hall antiquated and the chapel of St. Mary del Key decrepit" (Kermode, Hollinshead, and Gratton, "Liverpool 1207$1680, "$ p.109)
} 
alleys", three new churches, a new exchange "which...for its size is not to be paralleled in Europe,"26 a new infirmary, and the large and imposing Blue Coat School (a charity home for children), in addition to numerous chapels and alms houses. ${ }^{27}$ Liverpool, declared the author of a 1753 guidebook to the town, was "the most flourishing Sea-port, (next to [London]) in Great Britain." ${ }^{28}$ Inhabiting this "noisy, dirty, busy community" were 18,000 people, most of whom had come like William Davenport, to boom town Liverpool as migrants, enticed by the opportunity to make a trading fortune, and encouraged by the town's openness to strangers. ${ }^{29}$

Aged sixteen, Davenport arrived in Liverpool in May 1742 where he was to be "fitted for business \& to make my fortune." ${ }^{30}$ Davenport had been born in Red Lion Square London in 1725, to Davies Davenport I and Phoebe Ward, ${ }^{31}$ the fourth of a brood that would eventually grow to eleven children. ${ }^{32}$ The Davenport family, a line of gentry reaching back to the Norman Conquest, held long standing ties to Cheshire in their capacity as the Chief Foresters of Leek and Macclesfield, and major landholders in the area. ${ }^{33}$ Capesthorne, a large country manor near Macclesfield, came into the Davenport family estate in 1726 through the death of Penelope Ward's brother John. When the Davenport's inherited the title, a new hall was already under construction at Capesthorne, work that would not be completed until $1732 .{ }^{34}$ It is hence likely that William Davenport was born in London, rather than Cheshire,

\footnotetext{
${ }^{26}$ R. Williamson, The Liverpool Memorandum Book; or Gentleman's, Merchant's and Tradesman's Daily Pocket Journal, (Liverpool: 1753), p.7

${ }^{27}$ Quoted in Hyde, Liverpool and the Mersey, p.22

${ }^{28}$ Williamson, The Liverpool Memorandum Book, p.7

${ }^{29}$ Population figures are taken from Enfield, History of Liverpool, p.28; Such was the influx of outsiders, that the migrant population quickly eclipsed the native Liverpudlians; throughout the eighteenth century migrants accounted for over two thirds of Liverpool's population growth (Longmore, "Civic Liverpool: 1680-1800," p.119).

${ }^{30}$ William Davenport to John Ward, Liverpool, 22 May 1742, BDM

${ }^{31}$ Sir Bernard Burke, A Genealogical and Heraldic Dictionary of the Landed Gentry of Great Britain and Ireland, 4th ed., 2 vols., vol. 1, (London: 1862), pp 343-44

${ }^{32}$ Genealogical information has been taken from a Davenport family tree produced from the resources available at www.ancestry.com. Davenport's siblings were, in order of age, John (1722-c.1724), Davies (1723-1757), Ann (1724-?), Philip (1726-1727), Phoebe (1728-1741), Richard (1729-1799), Christopher (1730-1793), Thomasina (1732-1766), Thomas (1733-1786), and Charles (1735-1767).

${ }^{33}$ Richard Cavendish, "Capesthorne Hall, Cheshire", History Today, vol. 47, no. 12, (Dec. 1997), p.62; Stella Davies notes that the Davenports were the largest landholders in the Macclesfield region, a position they consolidated by substantially increasing their holding throughout the eighteenth and nineteenth centuries so that by 1879 the family held 10,166 acres (C Stella Davies, The Agricultural History of Cheshire 1750-1850, (Manchester: 1960) pp.28-29; Keith Giles, The Bromley-Davenport Papers: The Tenants of a Cheshire Estate 1700-1900, (Auckland: 1999) p.5)

34 Anonymous, "Capesthorne Hall: History", Capesthorne Hall, 2009, available from http://www.capesthorne.com/history.html.
} 
because Capesthorne Hall had not yet been completed. Alternatively, the family may have been in the capital so that William's father Davies could pursue his legal career. $^{35}$

At some point towards the end of the 1730s, possibly upon the death of his father Davies in May 1740, William Davenport returned to Cheshire and took up residence at Capesthorne. ${ }^{36}$ Little is known of William Davenport's youth there. It is likely, however, that he enjoyed a privileged upbringing. As the younger brother of Davies Davenport II, heir to the Davenport fortune, William could not remain at Capesthorne and enjoy the life of the landed gentleman. John Ward, Davenport's maternal grandfather and guardian following the death of his father, looked for a trade in which his grandson could make his fortune. Ward maintained a connection to Liverpool grocer William Whaley from whom he purchased imported luxury foodstuffs. ${ }^{37}$ When William Davenport came of age, Ward asked Whaley to take the young lad on as an apprentice in Liverpool and teach him the "art, mastery and business" of merchant accounts. ${ }^{38}$

William Whaley had himself come to Liverpool as a young Lancashire gentleman around the turn of the century. ${ }^{39}$ In addition to his grocery business, Whaley operated in the Chesapeake trade, shipping manufactured goods to the colonies in exchange for tobacco. He also speculated in the slave trade, sending a single vessel, Saint George, to the Guinea Coast every year to ship 150 enslaved

\footnotetext{
${ }^{35}$ Davies Davenport I is listed by Burke as a "Barrister-at-law of the Inner Temple, London" (Burke, Genealogical and Heraldic Dictionary, p.311).

${ }^{36}$ Davenport's mother Phoebe died in November 1737. By age fourteen William Davenport was thus an orphan.

${ }^{37}$ The Davenport family were also connected to John Knight, one of Liverpool's principal slaving merchants in the 1750s and 1760s. In May 1752, for example, William Davenport wrote to his brother Davies that "Messrs Whaley, Knight \& [Edward] Dean" wanted to pay him a visit at Capesthorne (William Davenport to Davies Davenport, Liverpool, 8 May 1752, BDM).

${ }^{38}$ The phrase "art, mastery and business" is taken from the apprenticeship forms of Christopher Davenport, William's younger brother, who came to Liverpool in 1747. The indenture was a standard legal document and therefore it is reasonable to assume that William Davenport's own apprenticeship would have the same phrase included. ("Indenture of Christopher Davenport", Liverpool, 29 August 1747, BDM)

${ }^{39}$ A receipt in the Clerk Hill Muniments at the Lancashire Record Office (DDG 1/3, 7/1/1722) states that William Whaley was living in Liverpool in 1722 when he received a $£ 1,000$ dowry from his marriage to Esther Baldwin. The same document describes Whaley as a "merchant, son and heir of Ralph Whaley of Blackburn, gentleman." Whaley must thus have come to Liverpool from Blackburn prior to 1722. The Lancashire parish records record Whaley's marriage to have occurred on 18 Dec 1722 at St Mary the Virgin in Blackburn ("Ancestor Search in the County of Lancashire", Lancashire Online Parish Clerks, 2009, available from http://www.lan-opc.org.uk/Search/indexp.html) implying that Whaley maintained a close connection to his home town even after fixing himself in Liverpool.
} 
Africans to the Americas. ${ }^{40}$ Whaley's participation in the tobacco and slave trades placed him in the upper echelon of Liverpool's merchant families as both trades required sums of capital. In the 1740s a hundred ton slaving vessel like Saint George required approximately $£ 3,000$ to purchase and fit out. Similarly the start up capital for a tobacco trading firm ranged from $£ 5,000$ to $£ 10,000$, sums that exceeded the means of even middling merchants, making the slave and tobacco trades the preserve of elite traders. ${ }^{41}$ William Whaley's firm, however, was by no means the largest or most prestigious in Liverpool. Foster Cunliffe \& Sons, for example, owned shares in twenty-six vessels trading to Africa, the Americas, and Europe, in addition to five tobacco stores in Maryland "remitting between 500 and 1600 hogsheads of tobacco annually"; and the Gildarts' company exceeded Foster Cunliffe \& Sons firm in size. ${ }^{42}$ Even these great Liverpool houses were eclipsed by the tobacco firms in London, where merchant tycoons carried on a booming trade with the North American colonies. William Whaley's merchant house was thus in the upper reaches, but far from the summit, of Britain's trading hierarchy.

Joining a prestigious trading firm such as Whaley's required substantial sums of money. Davenport's seven year apprenticeship cost $£ 120$, paid for by his grandfather, a fee that acted as a barometer to the quality of the apprenticeship. ${ }^{43}$ In London apprenticeship fees could reach as high as $£ 500$ to place an aspiring youth in the East India or Levant companies. These, however, represented the top fees: middling craft trades cost between $£ 10$ and $£ 30$ to join, just within the reaches of a well to do yeoman family. ${ }^{44}$ The sum of $£ 120$, by contrast, exceeded all but the richest families. Moreover, the initial fee did not include the maintenance of the apprentice, which added an extra $£ 25$ per annum to the apprenticeship, slightly more than the

\footnotetext{
${ }^{40}$ Voyages Database 90056, 90057, 90058, 90059, 90054; Whaley's participation in the Africa trade may have been what attracted Davenport to his firm. For example, when considering a merchant house for his brother Christopher to serve his apprenticeship with, William Davenport wrote to his grandfather advising him that John Welch, a local linen draper and "churchman," would be ideal as he was "pretty much concerned in the Guinea and West India trade, which may be further useful \& beneficial to my brother" (William Davenport to John Ward, Liverpool, 6 June 1746, BDM).

${ }^{41}$ Jacob M. Price, Capital and Credit in British Overseas Trade: The View from the Chesapeake, 17001776, (Cambridge, Mass.: 1980), p.41

${ }^{42}$ Tyler, "Foster Cunliffe and Sons", p 246-247

${ }^{43}$ Richardson, "The Accounts of William Davenport," p.61

${ }^{44}$ Refford, "Bonds of Trade" p.118
} 
wages of a common working man, but easily affordable sums for the wealthy Davenports. $^{45}$

Having fixed himself in Liverpool, Davenport began his training as a grocer. Although the term "grocer" now refers to a retailer of any foodstuffs, the eighteenth century grocery trade only encompassed foreign produce such as sugar, tobacco, citrus fruit and tea. ${ }^{46}$ The luxury status of these items made the grocery trade the preserve of upper class traders. ${ }^{47}$ Moreover, the grocery trade provided an excellent education for an aspiring merchant. Adam Smith declared that "Besides possessing a little capital" the grocer

must be able to read, write and account, and must be a tolerable judge too of, perhaps, fifty or sixty different sorts of goods, their prices, qualities, and the markets where they are to be had the cheapest. He must have all the knowledge, in short that is necessary for a great merchant. ${ }^{48}$

The skills learnt as a grocer transferred to the Africa trade. Slave trading merchants had to draw together trading assortments of thirty or more different commodities, and assess their quality and value to African middlemen. Like the grocer, the Africa merchant also had to correspond with traders spread throughout the globe: they communicated orders for goods to European manufacturers, sent specific instructions to ship captains, and arranged slave sales with American factors.

As an apprentice in Whaley's merchant house, William Davenport became well acquainted with an intricate web of customers, suppliers and employees. Merchants expected their apprentices to accustom themselves with their business by spending as much of their time as possible in the company offices, dining with their

\footnotetext{
${ }^{45}$ The annual maintenance has been estimated from records of Christopher "Kit" Davenport's apprenticeship. William Davenport acted as Kit's purser, receiving cash from their grandfather John Ward and paying it over to Kit's creditors as and when needed. These payments are detailed in William Davenport's personal cash book, commencing on 1 June 1747. The first transaction is Kit's initial apprenticeship fee of £120. In addition to his fee, Kit’s "board and schooling" at a Mr Pulford's house cost the family $£ 20$ per annum. Kit also received French lessons from David Jefferies for just over $£ 2$. Finally, incidental expenditures such as the cleaning and mending of clothes cost an extra $£ 3$. Presumably William Davenport received the same schooling and allowance for his own apprenticeship. (Personal Cash Book 1747-1760, Liverpool, D/DAV/2, ff.4,10,17)

${ }^{46}$ Doctor Johnson defines the grocer as "a man who buys and sells tea, sugar and plums for spices for gain" and grocery as "tea, sugar, raisins, spice" (Samuel Johnson, A Dictionary of the English Language, vol. 1, (London: 1755), p.944).

${ }^{47}$ In 1753, for example, Davenport was selling a pound of tea for nine shillings; one hundred oranges for two and a half shillings; and a pound of ginger for a shilling. Given that a common man could earn, on average, just under a shilling a day, these items were out of the reach of all but the upper classes (Waste Book 1745-1766, Liverpool, ODAV, ff.81,87,88).

${ }^{48}$ Adam Smith, An Inquiry into the Nature and Causes of the Wealth of Nations, vol. 1, (London: 1776), p.138
} 
masters and running errands to their merchant associates. When not at work, masters made their apprentices fill their spare time reading through the firm's correspondence. ${ }^{49}$ Later in his apprenticeship Davenport would also have written to Whaley's correspondents in his own name. In this way Whaley ensured that Davenport achieved one of the crucial objectives of apprenticeship: developing a network of business contacts that he could draw upon once a merchant in his own right.

Whaley further inducted Davenport into the Africa trade by encouraging him to invest in slaving vessels during the final two years of his apprenticeship. In April 1747 Davenport wrote to John Ward that he was in "ye latter end of my apprenticeship and am obliged to go into company pretty often." ${ }^{50}$ Four months later he requested money from his grandfather to make his first investment in the slave trade, writing that "Mr Whaley tells me 7 or $£ 800$ will be enough and cannot do with less." ${ }^{51}$ Davenport's start up capital matched that received by other apprentices. Christopher Hasell, another Cheshire gentleman who apprenticed in 1753 to merchant John Blackburn, received $£ 1,000$ to fit him out for business. ${ }^{52}$ Similarly, George Clowes, another of Whaley's apprentices, was "fitted out very handsomely" by his family. ${ }^{53}$ Davenport’s $£ 700$ may have been a relatively minor investment in the slave trade given that vessels cost up to $£ 5,000$ to fit out, but compared to the average man’s wages of just $£ 20$ per annum these were astronomical sums accessible to only a privileged few.

Having received a cash injection from his family, Davenport invested his capital in the newly constructed ship Chesterfield, destined for Angola, and the Saint George, outfitting for Bonny. Davenport's investments in two slaving vessels at just twenty-two years of age was unusual. The vast majority of Liverpool merchants made

\footnotetext{
${ }^{49}$ The instructions for the employees and apprentices of Herries \& Company of London had as general rule number seventeen, for example, "In order to have a right Notion of the thread of the Business... they must at their spare moments read all the Letters received \& wrote by the House" (Jacob M. Price, "Directions for the Conduct of a Merchant Counting House, 1766", Business History, vol. 28, no. 3 , (1986), p.141).

${ }^{50}$ William Davenport to John Ward, Liverpool, 14 April 1747, BDM

${ }^{51}$ William Davenport to John Ward, Liverpool, 29 August 1747, BDM; In addition to the money received from his grandfather, Davenport seems to have drawn heavily on his extended family by borrowing cash from them on interest. In October and November 1747, Davenport received from "Mrs Egerton”, his aunt, $£ 450$ “on bond.” In October 1749 he took out a further mortgage of $£ 300$ from Mr John Broomfield (Personal Cash Book 1747-1760, Liverpool, D/DAV/2, ff.1,3,12).

${ }_{52}$ M.M. Schofield, "A Good Fortune: The Marriage of Christopher Hassell of Liverpool, Merchant 1765", Transactions of the Historic Society of Lancashire and Cheshire, vol. 138, (1989), p.85

${ }^{53}$ William Davenport to John Ward, Liverpool, 14 April 1747, BDM.
} 
their first slaving investment in their early to mid thirties, well after they had established themselves as resident merchants. ${ }^{54}$ Even men who apprenticed at a similar age to Davenport did not invest in the slave trade until later in their careers. The Heywood brothers Arthur and Benjamin, for example, came from their native Ireland in 1731 and 1741, respectively, binding themselves apprentice to Guinea merchants. Yet they invested in the slave trade at the ages of twenty-seven and thirtythree. The sons of existing Liverpool slaving merchants were the exception to this rule whereby thirty was a benchmark age to first invest in the Guinea trade. The Earles, Tarletons and Crosbies all introduced the sons of the family to the business early, making them partners in vessels from as young as eighteen. Other young investors, such as Thomas Staniforth, Thomas Foxcroft, George Hutton and Richard Wickstead, came from affluent backgrounds being, like Davenport, the sons of gentlemen. ${ }^{55}$

Davenport's family wealth played a crucial part in establishing him as a youthful Africa merchant. Without the support of his rich family, Davenport would have had to earn his slaving capital in another industry, preventing him from joining the slave trade until his late twenties or early thirties. With the backing of his grandfather, however, Davenport could establish himself as a partner in Whaley's firm, and hence gain a foothold in Liverpool's slaving merchant community from the age of twenty-two. Davenport's family connections would continue to serve him well throughout his career: younger brothers Christopher, Thomas and Richard Davenport each invested in their brother William's slaving ventures at various times, contributing as much as $£ 40,000$ in capital. ${ }^{56}$

In September 1749 William Davenport received the freedom of Liverpool. ${ }^{57}$ Freeman status allowed Davenport to cast a vote in elections and to trade in his own name, establishing him in Liverpool's small elite: in 1749 22,000 people populated

\footnotetext{
${ }^{54}$ The following is based upon the biographical data collected by David Pope in his study of Liverpool's leading slave traders (Pope, "Wealth and Social Aspirations," pp.194-207) combined with the ownership data from the Voyages Database.

${ }^{55}$ Ibid.,

${ }^{56}$ The brothers were involved in the following number of voyages, with their period of trading in parenthesis: Christopher, thirty-seven (1753-1777); Richard Davenport, eleven (1768-1772); Thomas Davenport, thirteen (1774-1780); (Voyages Database and Davenport papers).

${ }^{57}$ Davenport spent $£ 1,1$ on 15 September 1749 for "Fine, Fees \& treating officers at being sworn a freeman of Liverpool” (Personal Cash Book 1747-1760, D/DAV/2, f.19).
} 
Liverpool, of whom just 2,000 possessed freeman status. ${ }^{58}$ Davenport continued to trade in partnership with Whaley after gaining freeman status. As Perry Gauci argues, new merchants faced the "enormous task" of establishing themselves in a highly competitive and tightly intertwined commercial community. ${ }^{59}$ Remaining with one's master allowed the former apprentice to cultivate business contacts and to grow their often meagre capital into a sufficient sum to start up their own firm. Davenport certainly needed to improve his capital stock before he could strike out on his own. On the day he received his freedom Davenport held no more than $£ 1,000$ in liquid assets, and had $£ 600$ tied up in slaving vessels, more than enough to invest in further slaving shares, but an insufficient amount to secure goods on credit for an independent venture, an important factor in the Africa trade (see chapter three). ${ }^{60}$

After a further four years and five slaving ventures, William Davenport, in 1753, established his own trading partnership. In that year, William Davenport, together with his younger brother Christopher, Lawrence Spencer, Thomas Rumbold, and Thomas Foulkes, purchased the ninety-two ton ship Charming Nancy for the Gambia market. ${ }^{61}$ William Davenport \& Company was by no means a large slaving firm. The Gambia market required a low level of investment, as small, inexpensive vessels of less than one hundred tons could trade at the river. ${ }^{62}$ As a result, minor traders and inexperienced partnerships seeking returns on speculative investments often traded there. Slaving firms trading to other, larger regions dwarfed Davenport's company. In the same year as Davenport sent Charming Nancy to Gambia for 170 enslaved Africans, Liverpool's two largest slaving firms-John Knight \& Company and John Welch \& Company — each sent four large ships to the Guinea coast, carrying to the Americas 2,500 captives. At the same time, Knight and Welch each financed five vessels to sail directly to the Americas for sugar and tobacco. Davenport, by contrast, had no investments in non-slaving vessels. ${ }^{63}$

Whilst small by contemporary standards, Davenport's firm was remarkable for the backgrounds of its investors. His partnership was comprised entirely of young

\footnotetext{
${ }^{58}$ Population figure is from Enfield, History of Liverpool, p.28; The number of Freemen is from Picton, Memorials of Liverpool, p.202

${ }_{59}$ Perry Gauci, The Politics of Trade : The Overseas Merchant in State and Society, 1660-1720, (Oxford: 2001), p.73

${ }^{60}$ Personal Cash Book 1747-1760, Liverpool, D/DAV/2, f.14

${ }^{61}$ Voyages Database 90478

${ }^{62}$ Refford, "Bonds of Trade" p.220

${ }^{63}$ Williamson, The Liverpool Memorandum Book, pp.17-19
} 
men his own age; none of the partners were older than thirty-one. ${ }^{64}$ The youthful character of William Davenport \& Company made the firm something of an anomaly as slaving firms ordinarily contained a mix of experienced and inexperienced partners. ${ }^{65}$ Forming a company made up entirely of youthful merchants was, therefore, an ambitious step for both Davenport and his associates. Having limited experience in the Africa trade there was every chance that the vessels could be fitted out with a poor trading assortment, that they would choose unreliable West India factors, or that their captains would make a mediocre purchase on the coast, not to mention the risks of the sea. The fact that Davenport continued with the venture in spite of the risks demonstrates that he and his associates believed in their abilities, despite their youth.

Soon after forming his own company, Davenport and Whaley parted ways. In 1754, Edward Lowndes \& Company, an eminent merchant house with whom Whaley was "largely concerned in trade \& liable to pay the partnership debts" folded. ${ }^{66}$ Lowndes' collapse financially crippled William Whaley: prior to 1754 he had been one of Liverpool's principal slaving merchants, sending four vessels a year to Africa; after 1754, Whaley's only investment was a minor share in the Gambia ship Rainbow. ${ }^{67}$ With his finances in ruins, Whaley sold his shares in the slavers Chesterfield and Orrel, ending his twelve year association with William Davenport. Aged twenty-nine, William Davenport was now completely independent of his former master.

As an independent merchant William Davenport leased offices in Liverpool's Drury Lane, a narrow alley in the heart of Liverpool's commercial district. ${ }^{68}$ John

\footnotetext{
${ }^{64}$ When the Charming Nancy departed Liverpool on her first voyage on 26 July 1753, the ages of the partners were: William Davenport 27; Christopher Davenport 23; Lawrence Spencer 31; Thomas Rumbold 30; and Thomas Foulkes 26 (Voyages Database; Pope, "Wealth and Social Aspirations," pp.194-207).

${ }^{65}$ Davenport's previous investments in the Chesterfield and Saint George, for example, had been with Robert Hallhead and William Whaley, each of whom had twelve years experience in the trade; John Clayton, with nine years in the trade; Edward Lowndes, with seven years experience; Peers Legh, with six years experience; and John Williamson with three years (Ibid.).

${ }^{66}$ William Davenport to Davies Davenport, Liverpool, 15 February 1754, BDM

${ }^{67}$ Voyages Database: 90465, 90466, 90467; Rainbow's final voyage suffered a series of misfortunes that may have put Whaley off the Africa trade as it was his last slaving investment. ("Case of the Rainbow, 1758" in Elizabeth Donnan, Documents Illustrative of the History of the Slave Trade to America: The Border Colonies and Southern Colonies, 4 vols., vol. 4, (Buffalo, NY: 2002), pp.370-2) In 1759 Whaley disappears from Liverpool's slaving community. He died in 1762 (Voyages Database; Pope, "Wealth and Social Aspirations," p.206).

${ }^{68}$ Davenport moved into his Drury Lane address some time before 1766 when the first Liverpool directory lists him as resident there (J. Gore, The Liverpool Directory for the Year 1766, (Liverpool:
} 
Dignan, in his 1847 satire The Slave Captain, described eighteenth century Drury Lane as consisting of "the better class of private houses, mostly inhabited by captains, for the inroads of commerce had not changed the character of the locality." "69 Dignan was correct, as no less than five captains inhabited the narrow street in 1766, in addition to four large slaving merchants. ${ }^{70}$ At its northern end Drury Lane adjoined with Water Street, one of Liverpool's major thoroughfares and "a favourite place of residence for the higher class of Liverpool merchants" amongst whom were many of Liverpool's principal Guinea traders. ${ }^{71}$ Turning onto Water Street, Davenport's office was just one hundred yards from the Exchange, and from there the Old Dock, the mooring place of Africa ships, easily could be reached through the city centre.

For the first nine years of his career as an independent merchant 1754-1763, Davenport invested relatively little in the African slave trade. From 1754, when he separated from Whaley, until 1763, when the Seven Year's War ended, he invested, on average, $£ 1,278$ per annum in slaving vessels (Figure 1). In the peak years of the war 1758-1760, Davenport moved away from slaving because French privateers captured nine of the ten vessels he held shares in. ${ }^{72}$ Once the war swung in favour of Britain, Davenport doubled his speculation in the slave trade. Even after increasing his slaving investment though, Davenport was still a bit player in the Liverpool slave trade because he worked as a general merchant, with the Africa trade forming just one of many investments in a varied portfolio (see chapter three).

1766), p.10). It is reasonable to assume that Davenport moved into his own offices once he separated from Whaley. Hence he likely took up residence in Drury Lane some time in the mid to late 1750s.

${ }^{69}$ John Dignan, The Slave Captain; a Legend of Liverpool, (London: 1847), p.6

${ }^{70}$ The slaving merchants were Isaac Blackstock, Thomas Middleton, John Parker and Samuel Shaw. Parker was a close associate of Davenport, and invested alongside him on thirty-six occasions (Based upon the ownership data in the Voyages Database; Gore, Liverpool Directory 1766)

${ }^{71}$ Quoted in Picton, Memorials of Liverpool, vol.2, p.86

${ }^{72}$ Based on Davenport's documented investments in the Voyages Database 
Figure 1: Pounds sterling invested per annum by William Davenport in the Liverpool slave trade 1748-1786

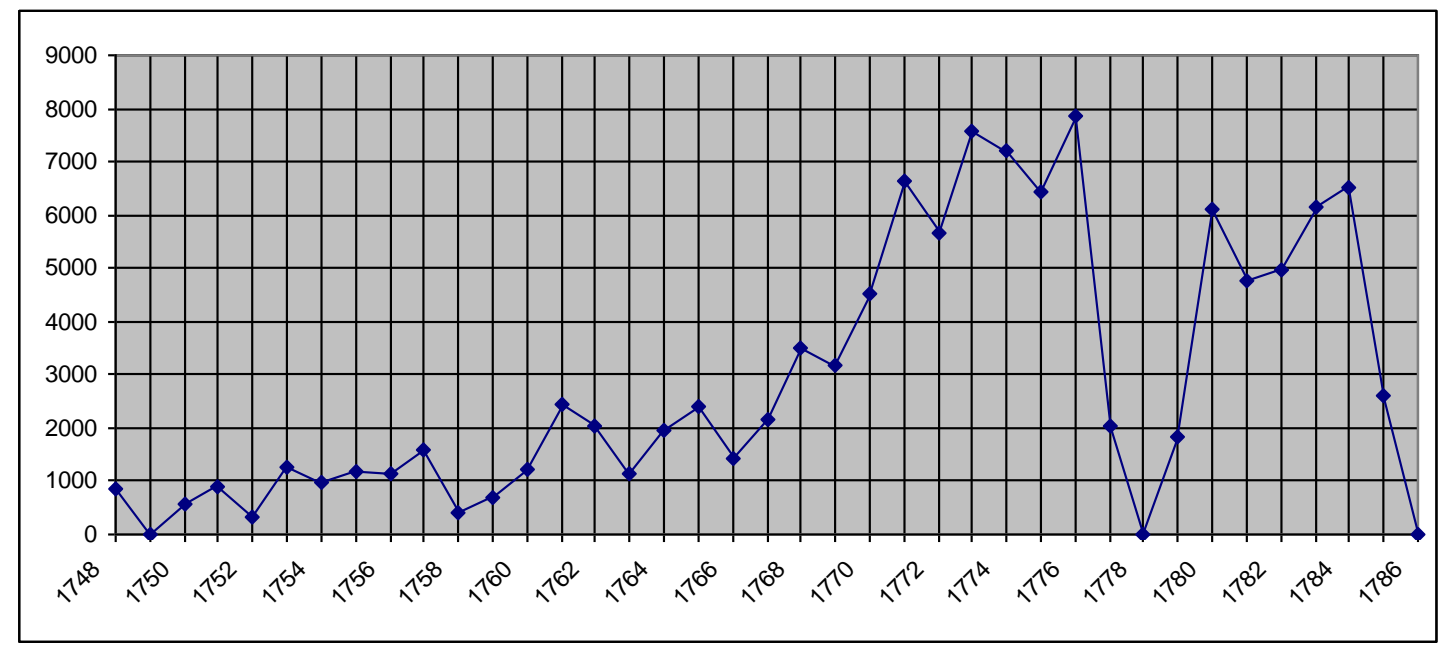

Source: Voyages Database and the Davenport Papers.

Davenport continued to operate as a small merchant in the slave trade until 1766-the key year in his slaving career. From then onwards he substantially increased his speculation in the Guinea trade so that by 1771 he had tripled his slaving investment from its 1766 level. Specialisation played a crucial part in Davenport's rapidly expanding slaving business. By marketing his slaves to the Ceded Islands, French possessions handed to Britain in the peace of 1763, and shifting focus in Africa to the larger Bight of Biafra region, Davenport became a true specialist in the slave trade. At the same time he geared his Liverpool business specifically towards the Africa market and committed all of his resources to the slave trade (see chapter two). As a result, the mid 1770s marked the peak years of his slaving career, with $£ 7,592$ invested in slave ships in 1774 alone. Davenport's growing stature reflected itself in his physical assets: during the 1770s his company operated from a large office and warehouse on fashionable King Street, a wine vaults on Harrington Street, and from his residence in Drury Lane. ${ }^{73}$

The American War abruptly halted Davenport's ambitions. The American embargo on British imports, coupled with a collapse in planter credit put Liverpool's "once extensive trade to Africa... at a stand." ${ }^{, 74}$ Although many Liverpool merchants

\footnotetext{
${ }^{73}$ John Gore, Gore's Liverpool Directory, for the Year 1774, (Liverpool: 1774), p.16; J. Gore, Gore's Liverpool Directory for the Year 1777, (Liverpool: 1777), p.23; J. Gore, Gore's Liverpool Directory, (Liverpool: 1781), p.24

${ }^{74}$ Anon. Liverpool General Advertiser, Liverpool, 29 September 1775
} 
quickly abandoned the slave trade, Davenport continued to fit out slaving vessels in 1776. Davenport perhaps took an overly optimistic view towards the American War, in the expectation that the army would bring a quick resolution to the conflict, an opinion in keeping with his family's Tory background. ${ }^{75}$ In November 1775, for example, a West Indian factor described Davenport as being "upbeat with generosity and confidence." ${ }^{, 76}$ His 1776 ventures were all financial failures, however, causing him to rapidly withdraw his capital from the trade. Just as Davenport's slaving business had more than quadrupled in size during the boom years 1766-1776, so it quickly shrank during the war, from $£ 7,787$ invested in 1776 to $£ 2,051$ in 1777 , and then to zero in 1778. In February 1777 he wrote to his West India factors that "I have not a ship out nor a share in any, but a very small one in the Dalrymple as a privateer [and slaver], \& she has been unsuccessful, \& her cruize very near over."77 With no further investments in the slave trade, 1778 marked the lowest ebb of Davenport's slaving career.

Davenport's absence from the Liverpool slave trade was short lived. Suspecting that the West Indian planters would readily purchase enslaved Africans, and that they could be acquired cheaply on the Guinea coast, Davenport joined with his close associates to fit out three slaving ventures in 1779. Davenport's intuition proved correct: the voyages proved a great success. Taking advantage of the favorable market conditions, Davenport quickly re-kindled his slaving career, joining in an upsurge in the Liverpool slave trade upon the peace of $1783{ }^{78}$ From 1783 to 1786 he invested in thirteen slaving ventures, the last being the ship Essex. ${ }^{79}$ When the Essex arrived in Liverpool on 12 August 1786, however, Davenport then aged sixty had decided to end his career in the British slave trade.

\footnotetext{
${ }^{75}$ Davenport's grandfather John Ward (1670-1749) was “a leading Hanoverian Tory" Member of Parliament for Thetford, Norfolk (Romney Sedgewick, The History of Parliament : The House of Commons, 1715-1754: Members E-Y, 3 vols., vol. 3, (London: 1970), p.99). His brother Thomas Davenport also sat as MP for Newton, Cheshire in the period 1780-1786 and supported Tory leader Lord North, "both in office and opposition" (Lewis Namier and John Brooke, The History of Parliament : The House of Commons, 1754-1790: Members a-J, 3 vols., vol. 2, (London: 1964), pp.302-303).

${ }_{76}$ James Merson to William Davenport, Dominica, 28/11/1775, DDAV7

${ }^{77}$ William Davenport to Vance, Caldwell \& Vance, Liverpool, 28 February 1779, D/DAV/1

${ }^{78}$ For example, in 1783 Liverpool slaving vessels embarked 17,396 slaves, and in 1784 29,634 (based upon slave embarkation volumes in the Voyages Database).

${ }^{79}$ Voyages Database 82974; Davenport held a 3/16ths share in another slaving vessel Perseverance until 1792 when he sold it to Thomas \& William Earle. However, the vessel completed its last slaving voyage in 1785 (Voyages Database 83063), so it may have lain up, or been engaged in freighting to the West Indies.
} 
Davenport does not state why he decided to retire in mid-1786. Perhaps he acted in response to the campaign to abolish the slave trade. In 1786, when Davenport's last ships were at sea, pamphlets circulated in Britain condemning the slave trade's cruelty, and in 1787 the abolitionist Thomas Clarkson visited Liverpool to investigate the town's links to the triangular trade. There he met two of Davenport's key merchant partners: Ambrose Lace and John Copeland (also spelled Coupland). After his meeting with the two men, Clarkson:

began to perceive that I was known in Liverpool, as well as the object for which I came [abolition]. Mr. Coupland, the slave-merchant... had given the alarm to those who were concerned in the trade, and Captain Lace, as may be now easily imagined, had spread it. ${ }^{80}$

Given Davenport's close ties to Copeland, Lace, and the wider merchant community, he undoubtedly became aware of Clarkson's presence in Liverpool and his designs against the trade. Moreover, Davenport maintained a family connection to the notorious Zong case that had acted as a spark for the abolitionist campaign. Davenport's younger brother Thomas had acted as a defence lawyer for the Zong's insurers in 1783, and had argued that the vessel's owners had no right to claim reimbursement for the slaves cast overboard to their death. ${ }^{81}$ Through his brother's involvement in the Zong case, and Clarkson's Liverpool visit, Davenport must have been well aware that the building campaign against the slave trade would impact upon his livelihood, and perhaps result in slurs upon his character should he remain in the trade.

Age also played a part in Davenport's retirement. At sixty Davenport was by now an old man, making the role of managing partner of slaving vessels a difficult one; having to coordinate the financing, cargo and direction of a slaving vessel was a taxing proposition even for a young man. Age had also taken its toll on Davenport's former partners. William Earle, with whom Davenport had invested in over fifty

\footnotetext{
${ }^{80}$ Thomas Clarkson, The History of the Rise, Progress, and Accomplishment of the Abolition of the African Slave-Trade by the British Parliament, (London: 1808), p.380

${ }^{81}$ Gregson v. Gilbert (1783), 99 English Reports 1378-1865, p.629; Thomas Davenport was part of the firm of Davenport, Pigott \& Heywood, defence attorneys for the insurers Gregson \& Company; He was certainly not acting out of altruism towards the murdered slaves. He himself had held shares in thirteen of his brother William's voyages, the last of which was the Ann, Captain Brancker (Voyages Database 80251), that returned to Liverpool in June 1782, just under a year before the Zong case was heard in court. Thomas Davenport appears to have been connected to Liverpool's merchant community through his marriage to the daughter of Robert Seel, an eminent tobacco trader in the town.
} 
voyages, had retired from the trade in 1785 , and died in 1788. Ambrose Lace, another of Davenport's key partners, retired in 1786, shortly before his meeting with Clarkson. Other partners had retired during the war such as Patrick Black, Alexander Nottingham, Felix Doran, John Parker and Thomas Hughes. ${ }^{82}$ Davenport's family members had also ceased their investment in the trade. Christopher Davenport left Liverpool in 1777 and took up residence in Bath after suffering financial losses and poor health $;{ }^{83}$ Richard and Thomas, William's other two younger brothers, had ceased their speculative investment in the Africa trade to pursue their legal and political careers. $^{84}$

Changes in the structure of the Liverpool slave trade may have also prompted Davenport's retirement. The period 1783-1785 saw a huge increase in the number of Guineamen trading from Liverpool, as the town's merchants sought to benefit from the West Indian planters renewed demand for slaves. ${ }^{85}$ The rush of ships to the Guinea coast placed a considerable strain on African markets. Peter Potter, captain of the Essex-Davenport's last venture in the slave trade-reported back to his owners that trade was "very slack" because of the number of slave ships at Old Calabar. Furthermore, the 319 enslaved Africans that Potter purchased were "old \& thin" with the result that he "had the misfortune to bury ninety", and twenty-four of the remainder were either "in the doctors list" or "thin or under size." 86 The Essex's voyage became a complete disaster for Davenport when Potter and his second mate were found guilty in Dominica of murdering one of the crewmen. ${ }^{87}$ With his only

\footnotetext{
${ }^{82}$ Based upon the ownership data in the Voyages Database

${ }^{83}$ Davenport wrote to his banker in 1779 that "My Bro[ther] Christopher is still in Bath for his health" (William Davenport to Joseph Denison \& Company, Liverpool, 26 December 1779, BDM); He remained there until his death on 23 May 1793 (Ledger Book 1788-1797, ODAV, ff.5,38).

${ }^{84}$ Both Richardson and Anderson state that Richard Davenport lived in Liverpool alongside his brothers William and Christopher. They presumably base this assumption on a Richard Davenport listed in the Liverpool directories as the owner of a mug warehouse. However, there is no evidence to support this assertion in the Davenport papers. In fact, Richard Davenport appears to have lived in London for most of his life before relocating to a substantial property at Court Garden House, Great Marlow, Buckinghamshire, in 1789, where he had been elected High Sheriff. Richard Davenport died in 1799 (Waste Book 1745-1766, Liverpool, ODAV; Waste Book 1766-1780, Liverpool, D/DAV/2).

${ }^{85}$ In 1780, for example, Liverpool merchants financed seventeen slaving voyages. In 1783, that number grew to forty-six. And in 1785, there were eighty-five Liverpool voyages (based upon the number of Liverpool clearances documented in the Voyages Database).

${ }^{86}$ Elijah Cobham to William Davenport, Dominica, 1 February 1786, D/DAV/15; Peter Potter to William Davenport, Dominica, 3 May 1786, D/DAV/15

${ }^{87}$ Potter seems to have escaped physical punishment for his crime as Lawrence Karberg wrote Davenport that "Judgement was obtained [against] them[,] what the Damages may be will not be determined until our next Court, wch will be March or April[; ] it will be a very expensive Business" (Cobham \& Karberg to William Davenport \& Company, Dominica, 3 July 1786, D/DAV/15). Potter
} 
remaining investment in the slave trade proving fruitless, the abolitionist campaign gathering pace, and his own advancing years, it is hence not surprising that Davenport retired from the trade in 1786.

Upon his retirement Davenport removed himself to Matthew Street in the north east of Liverpool, a new residence away from the bustle of the docks area but still close to the commercial hub of the town. ${ }^{88}$ Davenport's decision to remain in the modest surroundings of Matthew Street marks him out as something of an oddity among the slave trading fraternity. Many of his associates moved to the ostentatious villages of Everton or Kirkdale upon their retirement; others marked their ascendancy by purchasing manors in the surrounding countryside. ${ }^{89}$ These Liverpool merchants used their wealth to mimic the aristocracy, making a clear point that they had elevated themselves in the social hierarchy to a position of respectability on par with the nobility. Davenport, by contrast, had no such need to prove his aristocratic credentials, given his family's noble birth.

William Davenport provided himself a sizeable pension by carefully investing his trading fortune after his retirement. In 1786 he held $£ 25,000$ in assets, a portfolio that provided an annual pension of $£ 1,200$, an income placing him in the top five per cent of British society. ${ }^{90}$ Wrapping up his commercial career required little of Davenport's time. Each year he sent out drafts to former associates, settled his former trading debts and received cash from his own debtors. It is therefore likely that Davenport lived out his final years enjoying the fruits of his trading career. ${ }^{91}$

must have escaped Dominica before then because he was in Liverpool in March 1787 at the helm of the Iris, his last slaving voyage (Voyages Database 81913).

${ }^{88}$ Davenport's residence is listed as 40 King Street in the 1790 directory by Wosencraft, but this is probably his old counting house (Charles Wosencraft, The Liverpool Directory, for the Year 1790, (Liverpool: 1790), p.19). Gore lists Davenport's address in the same year as 16 Matthew Street, but makes no mention of his King Street address (J. Gore, Gore's Liverpool Directory, (Liverpool: 1790), p.45).

${ }^{89}$ In his description of Liverpool circa 1775, Brooke comments that "At Everton there were a few large houses, some of which had been erected by merchant of opulence;" (Brooke, Liverpool as It Was, p.155). Amongst these "merchants of opulence" were Africa traders Gill Slater, James Bridge, Joshua Rose, and William Gregson, who was "one of the earliest merchants to reside in the outskirts of the town" (Hughes, Liverpool Banks \& Bankers, p.viii). The gentrification of Liverpool's suburbs is clear from Horwood's map of 1803. Large residences with attendant gardens are shown belonging to John Backhouse, William Harper, William Earle Jr. and John Tarleton, all principal slave traders of the period.

${ }^{90}$ Ledger Book 1788-1797, Liverpool, ODAV, ff.2,3,33,34,36,37,39,40; Laurence H.Officer, "Purchasing Power of British Pounds from 1264 to Present" Measuring Worth, 2009, available from http://www.measuringworth.com/ppoweruk/

${ }^{91}$ Davenport's chief expenses in this period were dining at $£ 60$ per annum, and $£ 30$ per annum playing the lottery with his brother Christopher (Ledger Book 1788-1797, Liverpool, ODAV). 
William Davenport died on 31 August 1797, aged seventy-two. In a town where only one in fifteen men could expect to live beyond seventy, he had enjoyed a long and prosperous life. ${ }^{92}$ His obituary in Billinge's Liverpool Advertiser read:

On Thursday last, in the $73^{\text {rd }}$ year of his age, William Davenport, Esq. formerly an eminent merchant of this town. He was deservedly successful in his commercial pursuits which were always conducted with pleasant manners, strict probity and excellent punctuality. ${ }^{93}$

Costing just ten pounds, Davenport's funeral was held at St. Nicholas' church, Liverpool. ${ }^{94}$ By the time of his death few of his business associates survived. His family too had been reduced to just Richard, his younger brother, and Davies, his nephew, both of whom inherited Davenport's estate. His funeral must thus have been a small affair attended by his few surviving friends and relatives. ${ }^{95}$

Viewing Davenport's career in its entirety, we can gauge his status in the Liverpool slaving merchant community by comparing his level of investment in the slave trade to that of his contemporaries. Two historians have recently performed studies of the Liverpool slave trading community. In his $2005 \mathrm{PhD}$ dissertation Brian Refford documented the familial links, trading partnerships and status of the town's slaving merchants using the Trans-Atlantic Slave Trade Database CD-ROM. ${ }^{96}$ Two years later, David Pope also shed new light on Liverpool's merchants when he compiled and analyzed the biographical data of 178 leading slave traders. ${ }^{97}$ Both Refford and Pope gauged the relative size and status of each merchant using the number of their slaving voyage investments. Using this criterion, William Davenport was the largest slave trading merchant in the history of the Liverpool slave trade, having made 163 voyage investments during his career, twelve more than his closest rival William Boats (Table 1). Davenport's large number of investments places him,

\footnotetext{
${ }^{92}$ Statistics are from Enfield, History of Liverpool, p.34

${ }^{93}$ Anon., Billinge's Liverpool Adverstiser, Liverpool, 28 August 1797

${ }^{94}$ Residuary Settlement of William Davenport, Liverpool, c.1797, BDM; Richardson notes that Davenport was buried at St. Nicholas' Prescott but there is no record of this in the Lancashire Parish Records.

95 Davenport's funeral was especially frugal compared to that of John Bolton - an investor in 120 slaving voyages during 1783-1807-who died in 1837. Bolton's coffin was "covered with rich black velvet studded with silver nails" and accompanied by a procession of "three hundred boys... two hundred and fifty Gentlemen on foot... sixty gentlemen on horse back; thirty gentlemen's private carriages in a line" and a number of coaches (Matthews, "John Bolton: A Liverpool Merchant, 17561837", pp.112-113).

${ }^{96}$ Refford, "Bonds of Trade"

${ }^{97}$ Pope, "Wealth and Social Aspirations,"
} 
according to Refford, into a category of slaving merchants known as "super-traders, a handful of merchants who participated in more than 90 slaving ventures each." 98

William Davenport was also one of the most committed slaving merchants with a career spanning thirty-eight years, a feat exceeded by just three other slaving merchants: William Gregson, Francis Ingram and William Boats. The length of Davenport's career is particularly impressive because it spanned two wars. Ordinarily, wars culled a large number of slaving merchants as heavy financial losses bankrupted over exposed traders. During the American War, for instance, forty-one of Liverpool's leading slaving merchants left the trade-from a pre-war merchant community of 158 traders - and never invested thereafter. ${ }^{99}$ Amongst the casualties was William James - the largest pre-war investor in the slave trade-and Thomas Rumbold, both of whom quit the slave trade during the war. Samuel Sandys and Miles Barber were less lucky: both were bankrupted. ${ }^{100}$ Davenport, by contrast, maintained his connection to the Guinea trade throughout the war, and increased his slaving investments in its wake.

Although useful, viewing merchant status solely by their career length and number of voyage investments distorts their importance. Slaving firms ranged in size from sole traders to large partnerships of eight or more investors. Holdings in slaving vessels altered accordingly, from a one thirty-second share all the way to a whole share, whereby the entire cost of the voyage was met by a single merchant. Using the number of voyage investments as a criterion of status, a merchant taking one eighth shares in eight different voyages would be given eight times the importance of a merchant taking a whole share in a vessel. A better measure of merchant status is the actual amount of capital they invested in the slave trade. The level of investment for each merchant can be imputed by calculating an average cost per ton to outfit a slaving vessel, and then multiplying that cost by the total tonnage a trader invested in per the Voyages Database. By dividing the total voyage cost by the number of voyage investors, assuming that each investor takes an equal share in the vessel, we arrive at a total sterling investment for each slaving merchant.

Roger Anstey is the only historian to have performed a similar exercise. As part of his calculation of industry wide slaving profits, Anstey used data provided by

\footnotetext{
${ }^{98}$ Refford, "Bonds of Trade" p.192

${ }^{99}$ Based upon the ownership data in the Voyages Database

${ }^{100}$ William Bailey, Bailey's List of Bankrupts, Dividends, and Certificates, from the Year 1772, to 1793, vol. 2, (London: 1794), p.81
} 
British slaving merchants to Parliament in the 1780 s to arrive at a cost per ton of a slaving vessel: $£ 25.2$ per ton in $1761-1770$; 228.4 in $1771-1780$; 28.7 in $1781-1790$; $£ 30.2$ in 1791-1800; and $£ 29.3$ in 1801-1807. ${ }^{101}$ Anstey’s figures will be utilized, in addition to a pre-1761 outfitting cost of $£ 20.7$ per ton, based upon extant outfitting records. ${ }^{102}$ By utilizing Anstey's data in combination with the ownership information in the Voyages Database, we can, for the first time, assess Davenport and his contemporaries' actual sterling investments in the slave trade.

Before we proceed, it should be pointed out that assuming an equal division of shares in a slaving vessel and utilizing an average outfitting cost is admittedly problematic because some partners took out larger shares than others, and outfitting costs sometimes fluctuated between ventures and slaving regions. However, we can gain some idea of the above calculation's accuracy by comparing William Davenport's sterling investment per his records, which detail actual sterling costs and partnership shares for 110 of his 163 voyages, to his investment in the same voyages using the above calculation. On this basis, William Davenport's imputed sterling investment is $£ 92,919$, compared to his actual outlays of $£ 96,371$, yielding only a 3.5 percent margin of error. On the assumption that the calculation is accurate, we can use the ownership data in the Voyages Database, and summarises the career information of William Davenport and the nine largest slaving merchants of his generation defined here as those merchants born after 1715 but before 1740, and trading between 1740 and 1790 (Table 1).

\footnotetext{
${ }^{101}$ Anstey, The Atlantic Slave Trade and British Abolition 1760-1810, pp.43-45; The figures Anstey used in his original calculation have been divided by 1.81 to account for a difference in the system of tonnage used in the Voyages Database.

${ }^{102}$ The figure is based on the trading accounts of the Chesterfield (1757); Calveley (1760); Eadith (1760); and Tyrell (1760) — the only extant Trading accounts from the period-all of which are in the Davenport papers.
} 
Table 1: Ten Largest Liverpool Slave Trading Merchants, Trading c. 1740-1790

$\begin{array}{lllllllll}\text { Name } & \begin{array}{l}\text { Yr of } \\ \text { Birth }\end{array} & \begin{array}{l}\text { Yr of } \\ \text { Death }\end{array} & \begin{array}{l}\text { Career } \\ \text { Begin }\end{array} & \begin{array}{l}\text { Career } \\ \text { End }\end{array} & \begin{array}{l}\text { Career } \\ \text { Length }\end{array} & \begin{array}{l}\text { No. } \\ \text { Inv }\end{array} & \begin{array}{l}\text { Solo } \\ \text { Inv }\end{array} & \begin{array}{l}\text { Total } £ \\ \text { Inv }\end{array} \\ \text { James, William } & 1734 & 1798 & 1759 & 1777 & 18 & 140 & 84 & 519,509 \\ \text { Boats, William } & 1716 & 1794 & 1753 & 1795 & 42 & 154 & 33 & 444,322 \\ \text { Barber, Miles } & 1733 & 1795 & 1758 & 1788 & 30 & 74 & 27 & 206,911 \\ \text { Gregson, Wm } & 1721 & 1800 & 1745 & 1793 & 48 & 142 & 0 & 155,702 \\ \text { Ingram, Francis } & 1739 & 1815 & 1761 & 1804 & 43 & 109 & 0 & 131,171 \\ \text { Copeland, John } & 1727 & 1792 & 1760 & 1793 & 33 & 84 & 15 & 131,467 \\ \text { Davenport, Wm } & 1725 & 1797 & 1748 & 1786 & 38 & 163 & 0 & 127,044 \\ \text { Rumbold, Thomas } & 1724 & 1791 & 1754 & 1783 & 29 & 75 & 4 & 112,464 \\ \text { Sandys, Samuel } & 1732 & 1819 & 1770 & 1776 & 6 & 47 & 6 & 103,051 \\ \text { Earle, William } & 1721 & 1788 & 1754 & 1788 & 34 & 117 & 0 & 98,700 \\ & & & & & & \mathbf{1 1 0 5} & & \mathbf{2 , 0 3 0 , 3 4 1}\end{array}$

Source: For Biographical information Pope, "Wealth and Social Aspirations," pp.194-210; for career and investment information, the Voyages Database.

Using the criterion of actual capital invested, William Davenport was the seventh largest slave trading merchant of his generation. Slaving kingpins William James and William Boats dwarfed Davenport, outstripping his investment by a factor of four, despite investing in slightly fewer voyages. Miles Barber-a merchant described in 1776 as managing "the greatest Guinea House in Europe"-also outlaid seventy-five percent more on the slave trade than Davenport. ${ }^{103}$ James, Boats and Barber far exceeded Davenport because they traded in small partnerships. William Boats, the second largest slaving merchant by sterling investment, typically invested alongside just one or two other merchants: until 1777 with William Gregson; and from 1787 with James Percival and Thomas Seaman. ${ }^{104}$ Similarly, William James invested alongside other merchants in only one out of three ventures, and acted as a sole owner for a majority of his eighty-four ventures. Barber too preferred to trade alone or in small partnerships, and rarely partnered with more than three men. Davenport, by contrast, never acted as a sole trader, and typically invested alongside six or more other merchants, taking on average an eighth share in each voyage. As a result he speculated less on the slave trade, whilst at the same time backing a much larger number of voyages than his contemporaries.

Davenport also invested less in the slave trade because of his specialisation in the Old Calabar and Cameroon markets in the eastern Bight of Biafra. These regions,

\footnotetext{
${ }^{103}$ Quoted in Melinda Elder, "The Liverpool Slave Trade, Lancaster and Its Environs," in Liverpool and Transatlantic Slavery, ed. David Richardson, Suzanne Schwarz, and Anthony Tibbles, (Liverpool: 2007), p.121

${ }^{104}$ Based on the ownership data in the Voyages Database
} 
although much more expensive to trade to than the small Gambia region, were overshadowed by the capital intensive Bonny and Gold Coast markets. At these latter trading locations, large burthen ships carried off sizeable cargoes of captives to be sold in the Americas. Gold Coast slaves, in particular, traded at a hefty premiumoften as much as twenty percent—because they were "almost universally esteemed" in the Americas, and because British forts exercised a monopoly on their export. ${ }^{105}$ Boats, Gregson and Thomas Rumbold all traded to Gold Coast or Bonny throughout their career, which helps to explain their leading position in the Liverpool slave trade. The other traders also differed in their patterns of specialisation. James and Barber both favoured the Sierra Leone region and Windward Coast, a stretch of coastline visited by smaller burthen, but still relatively expensive vessels due to the need to load large quantities of rice. Only William Earle matched Davenport's trading pattern with his specialisation in the Old Calabar market.

Whilst Davenport invested less in the slave trade than many of his contemporaries, he was ultimately much more successful in his pursuits. When William Davenport died he left an estate worth $£ 34,000$, far more than any of his contemporaries: William Gregson had the second largest estate at $£ 10,000$, followed by John Copeland, Thomas Rumbold and William Earle, each of whom possessed $£ 5,000$; Francis Ingram owned just $£ 1,500$ on his death bed. ${ }^{106}$ The value of James, Boats, Barber and Sandys' estates are unfortunately unknown. We can, however, conjecture that Miles Barber and Samuel Sandys' fortune cannot have been particularly great because of their bankruptcy. Equally, due to financial losses in the American War, William James probably passed away with little to his name. William Boats, by contrast, was perhaps the only one of the top ten merchants to come close to, or even exceed, Davenport's sizeable estate: he willed his two daughters $£ 13,000$ each, and probably gave his son Henry Ellis an even greater sum. ${ }^{107}$

William Davenport was thus one of the most financially successful slaving merchants of his generation, and indeed in the entire history of the Liverpool slave trade: only nine of the merchants in Pope’s analysis had estates exceeding $£ 30,000$, all of whom traded for slaves during the twilight years of the Liverpool slave trade, 1788-1807. Davenport's longevity and broad investment in the trade seems to have

\footnotetext{
${ }^{105}$ Rawley and Behrendt, Transatlantic Slave Trade, p.234

${ }^{106}$ Residuary Settlement of William Davenport, Liverpool, c.1797, BDM; Pope, "Wealth and Social Aspirations," pp.208-215

${ }^{107}$ Frances Wilkins, Manx Slave Traders, (Kidderminster: 1999), p.24
} 
been the key to his success. Other merchants such as James, Barber and Sandys who attempted to push heavily into the trade in a short a period of time failed miserably and were hence forced to leave slaving. Davenport and the other successful merchants of his generation, such as Boats and Gregson, carefully spread their investment over a lengthy career and in doing so ensured that they would not be caught out by seismic shifts in the slave trade, such as the onset of war.

Regardless of their level of success in the Africa trade, very few of the principal slaving merchants committed time to public service. Only William Gregson played a significant role in the public sphere when he served as mayor of Liverpool in 1762-1763 and Justice of the Peace in 1769. ${ }^{108}$ William Boats and Thomas Rumbold also served upon Liverpool's Common Council, but their ambitions reached no higher than the position of Alderman. Moreover, few of the merchants volunteered for the numerous positions at the custom house, docks, and charitable institutions: only Gregson, Rumbold and Copeland served in the posts, most of which seem to have been filled by lesser merchants. In 1774, for example, half of the public positions were filled by merchants with small investments in the slave trade. ${ }^{109}$

The senior merchants' commitment to the slave trade appears to have kept them out of the political sphere. Each of the leading slavers acted as managing partners of their vessels a task requiring a considerable amount of time, as they coordinated, directed and organised the voyage (see chapter two). Davenport and William James, in particular, must have had few diversions outside the counting house given that they personally managed up to ten vessels per annum in the peak years of their career 1770-1775. ${ }^{110}$ Boats, too, managed almost all of his slaving voyages. Given the amount of time needed to remain highly committed to the slave trade, it is not surprising that we see so little of the principal slaving merchants in the public sphere.

Although most of the principal slaving merchants seem to have avoided distractions from business, William Davenport in particular is notable for his reluctance to involve himself in political machinations affecting the slave trade. Davenport, unlike his contemporaries, never entered the Company of Merchants

\footnotetext{
${ }^{108}$ Hughes, Liverpool Banks \& Bankers, p.109; Gomer Williams asserts that William James was an MP for "some years". However, there is no record of this in any other history of Liverpool, or the House of Commons. (Williams, Liverpool Privateers, p.557)

${ }^{109}$ Gore, Gore's Liverpool Directory, for the Year 1774, pp.67-69

${ }^{110}$ Based upon the ownership data in the Voyages Database
} 
Trading to Africa, a body that met regularly to manage the trade. Neither did he apply his name to the petitions sent from Liverpool to London in support of the trade. ${ }^{11}$ Such was his reluctance to involve himself in politics that in 1777, when Davenport numbered amongst the few merchants still trading to Africa, he refused to join the African Committee, a society chaired by William Gregson that considered ways to save the trade from ruin. ${ }^{112}$

Davenport is also something of a peculiarity given his lifelong bachelorhood. Most of the other slaving merchants married, often choosing spouses to cement commercial ties. For example, William Earle married Anne Wynstanley, a union that connected him to fellow slaving merchants John Copeland and Robert Jennings, both of whom also married a Wynstanley sister. ${ }^{113}$ William Boats used his marriage to Elizabeth Brideson to bolster his trading connection to her father Paul, the leading importer of Guinea goods on the Isle of Man. ${ }^{114}$ Earle, Boats and Francis Ingram also used their trading wealth to improve the social standing of their offspring. In Earle's case his two sons Thomas and William Junior became scions of Liverpool's merchant elite, trading extensively with Europe and the Americas, and inducting their own sons into the ranks of the landed gentry. ${ }^{115}$ William Boats' son, Henry Ellis Boats, elevated himself to become an MP after attending Oxford University; similarly, Francis Ingram's son John became a lawyer after attending Cambridge. ${ }^{116}$ Despite Davenport's eligibility owing to both his wealth and birth, he had neither a wife nor children, and thus he left no legacy in Liverpool or Cheshire.

Having kept aloof from politics and without a familial legacy, William Davenport, unlike his contemporaries, rapidly faded into obscurity after his death. In 1852 Clarke Aspinall released Liverpool a Few Years Since, a personal history filled with descriptions of Liverpool's burghers. ${ }^{117}$ A year later, Richard Brooke published Liverpool As It Was, 1775 to 1800 , a vivid history of the town and its inhabitants,

\footnotetext{
${ }^{111}$ Richardson, "The Accounts of William Davenport," p.63; A single exception is a petition Davenport signed in support of the extension of Douglas Harbour, Isle of Man, in 1757 (Wilkins, Manx Slave Traders, p.37).

${ }^{112}$ Williams, Liverpool Privateers, p.562

113 The Wynstanley family was connected to the slaving merchant community through Daniel and Samuel Wynstanley, investors in eleven voyages from 1757-1761 (Voyages Database; Refford, "Bonds of Trade" pp.102-103).

${ }^{114}$ See Wilkins, Manx Slave Traders, pp.17-24 for a detailed study of Bridson and his relationship with Boats.

${ }^{115}$ Littler, "The Earle Collection", pp.96-97

${ }^{116}$ Pope, "Wealth and Social Aspirations," p.180

${ }^{117}$ Clarke Aspinall, Liverpool a Few Years since by an Old Stager, 3rd ed., (Liverpool: 1885)
} 
compiled from his aging father's memories and records from the municipal archives. Despite Brooke and Aspinall's books containing colourful descriptions of many leading slaving merchants, both failed to make a single reference to Davenport. ${ }^{118}$ Similarly, three nineteenth century historians of Liverpool Thomas Troughton, Thomas Baines and James A. Picton, made no mention of William Davenport. ${ }^{119}$ Even Liverpool and Slavery, a book that purposely set out to detail Liverpool's slaving history, ignored Davenport. Only Gomer William's 1897 History of the Liverpool Privateers and Letters of Marque made reference to William Davenport, and then only to note him as the owner of a number of slaving vessels and a privateer. ${ }^{120}$ Not until 1951, with Parkinson's first academic study of the newly discovered Davenport papers, did historians turn their attention to William Davenport's career.

Davenport's private nature explains his lack of attention from historians. In his small and anonymous house in Drury Lane, Davenport quietly conducted his business, never raising his voice in Liverpool's political forums, and never establishing a family in Liverpool to carry on his trading legacy or cement his ties to the city. Unlike his contemporaries, he never invested in land around the town, and hence no street bore his name. ${ }^{121}$ Neither did Davenport donate any of his fortune to charitable institutions such as the infirmary, library, hospitals or work houses. In short, Davenport was a transient member of Liverpool's community who felt no need to actively participate in the town's development.

Davenport also has been overlooked because he was eclipsed by merchants of a later generation. John Dawson, a privateering captain-cum-merchant, was probably

\footnotetext{
${ }^{118}$ Aspinall mentioned John Bridge Aspinall, John Bolton, Moses Benson, Thomas Leyland, George Rowe, William Harper, Arthur Heywood, Hugh Crowe, William James, Patrick Black, and Thomas Staniforth. Brooke's history included a tour through the town, describing each of Liverpool's streets and their "principal inhabitants" circa 1775. As part of his tour, Brooke at least mentioned every one of the principal slavers except Davenport (Brooke, Liverpool as It Was, pp.464-478).

119 Thomas Troughton, History of Liverpool, (Liverpool: 1810); Baines, History of the Commerce and Town of Liverpool, ; James A. Picton, Selections from the Municipal Archives and Records of the City of Liverpool from Ad 1700 to the Passing of the Municipal Reform Act, 1835, vol. 2, (Liverpool: 1886); Picton, Memorials of Liverpool,

${ }^{120}$ Williams, Liverpool Privateers, pp.253-254, 669

${ }^{121}$ Liverpool still contains Ashton Street, Blackburne Place, Blundell Street, Bold Street, Cropper Street, Cunliffe Street, Earle Road, Parr Street, Sir Thomas Street and Tarleton Street, all named after slave trading merchants or their families. In most cases, land was purchased by the trader who then laid out a street and named it after themselves. (Westgraph, Laurence, "Read the Signs: Street Names with a Connection to the Transatlantic Slave Trade and Abolition in Liverpool," English Heritage, 2008, available from http://www.englishheritage.org.uk/server/show/nav.18287).
} 
the largest slaving merchant in the history of the trade. ${ }^{122} \mathrm{He}$ invested substantial amounts of capital in the late 1780s after signing the asiento with the Spanish, a contract to ship eight thousand slaves per annum to their American colonies. ${ }^{123}$ In 1790 Dawson petitioned parliament against the abolition of the slave trade, claiming that he owned nineteen slave ships worth $£ 157,000$, most of which visited the Gold Coast where he also maintained factories. ${ }^{124}$ Dawson's speculation for this single year thus matched Davenport's entire career investment. Thomas Leyland also easily exceeded Davenport's slaving speculation after dispatching seventy-two slaving vessels to Bonny and the Congo River from 1783 until abolition in 1807 an outlay of $£ 280,000 .{ }^{125}$ These two merchants are just two examples of the large slave traders who began to dominate the trade from the 1780s until the turn of the nineteenth century, many of whom comfortably exceeded Davenport's investment in the trade. Hence these men were, as Gomer Williams wrote in 1897

the focus of scorching censure, while the older offenders, left far behind in the race for pelf, are comparatively forgotten, and their exceeding weight of guilt overlooked. $^{126}$

When we include later slaving merchants such as Leyland and Dawson, Davenport was probably in the range of the fifteenth to twentieth largest trader in the history of the Liverpool slave trade. Davenport was hence a large, but by no means the largest, of Liverpool's slaving merchant. We must bear in mind, however, that the period after the American War resulted in a large restructuring of the British slave trade. The passage of the Dolben Act and the parliamentary debates surrounding abolition substantially increased the size of slaving vessels. ${ }^{127}$ At the same time the volume of the Liverpool slave trade increased, reaching its peak in the years 17951805 when Liverpool slaving ships embarked approximately 300,000 enslaved

\footnotetext{
${ }^{122}$ As captain of the Mentor privateer, Dawson captured Carnatic a French East Indiaman valued at $£ 400,000$ including a box of diamonds worth $£ 135,000$, "the richest prize every taken... by a Liverpool adventurer." Dawson used his share of the booty to establish himself as a slaving merchant (Williams, Liverpool Privateers, p.239).

${ }^{123}$ Rawley and Behrendt, Transatlantic Slave Trade, pp.186-187

${ }^{124}$ F.E. Sanderson, "The Liverpool Delegates and Sir William Dolben's Bill", Transactions of the Historic Society of Lancashire and Cheshire, vol. 129, (1972), p.83, n.61

${ }^{125}$ Voyages Database; When Leyland died in 1828 he possessed $£ 600,000$, the largest estate of any slaving merchant in Liverpool's history. Leyland's success stemmed in large part from his banking business Leyland \& Bullins, a firm eventually absorbed by the Midland Bank/ HSBC group in 1908 (A.E Phillips, "Leyland and Bullins", British Banking History, 2003, available from http://www.banking-history.co.uk/leyland.html).

${ }^{126}$ Williams, Liverpool Privateers, pp.594-595

${ }^{127}$ Based on the ship size data in the Voyages Database
} 
Africans. ${ }^{128}$ This relentless pressure on African markets forced up slave prices so that between 1795 and 1807 the "average price paid for slaves by British traders at the African coast rose from $£ 15-16$ per slave to $£ 29-35$ per slave." ${ }^{\prime 29}$ As a result, slaving merchants trading at the end of the eighteenth century required a much larger capital base than Davenport and his contemporaries.

Given the shift in the financial organisation of the Liverpool slave trade, historians prior to the discovery of the Davenport papers ignored him in favour of the large traders such as Leyland and Dawson; men who traded at the end of the eighteenth century and beginning of the nineteenth centuries. This should not lead us to conclude that Davenport was unimportant in the history of the slave trade. As we have seen William Davenport was one of the longest serving, largest and ultimately most successful slaving merchant of his generation. Davenport's partnership investments in the slave trade thus masks the fact that he was one of the most significant slaving merchants in Liverpool's history. His significance is most important in the eastern Bight of Biafra markets of Old Calabar and Cameroon, which feature in chapter two on Davenport's marketing strategies in Africa.

\footnotetext{
${ }^{128}$ Based on the volumes of slave exports documented in the Voyages Database

${ }^{129}$ David Richardson, "Prices of Slaves in West and West-Central Africa: Toward and Annual Series, 1698-1807", Bulletin of Economic Research, vol. 43, (1991), p.35
} 


\section{Chapter 2: William Davenport's African Marketing Strategies: Old Calabar and Cameroon}

Though Liverpool slaving merchants wrote about "Africa" or "Guinea," they understood that there were numerous distinct markets along the 3,500 mile African Atlantic coastline from Senegal to Angola. In 1752, for example, a year before Davenport organised his first slaving venture, Liverpool slaving ships traded at eight different African markets. ${ }^{1}$ Some markets were regions, such as the Windward Coast or the Gold Coast. Others were ports such as Bonny and Old Calabar, both in the Bight of Biafra.

William Davenport was unique in the Liverpool merchant community in trading almost exclusively to two markets in the eastern Bight of Biafra: Old Calabar and Cameroon, port communities managed by African middlemen traders. Though geographically close (one hundred miles), Old Calabar and Cameroon were distinct markets whose African merchants conducted business in different currencies and demanded different assortments of European and Asian consumer goods. Studying how Davenport met the challenge of trading in two different African slaving markets helps to explain how he established himself as one Liverpool's largest and most successful slaving merchants.

There is a veritable "cottage industry" of studies on Old Calabar. ${ }^{2}$ By contrast, historians have mostly overlooked the smaller Cameroon trade, because there are few written sources about the area before $1850 .{ }^{3}$ Davenport's business accounts are an

\footnotetext{
${ }^{1}$ From west to east the markets were: Gambia, the Windward Coast, the Gold Coast, Benin, New Calabar, Bonny, Old Calabar, and Angola (Williamson, The Liverpool Memorandum Book, p.16-17)

${ }^{2}$ Paul E. Lovejoy and David Richardson, "Trust, Pawnship, and Atlantic History: The Institutional Foundations of the Old Calabar Slave Trade", American Historical Review, vol. 104, (1999), pp.333355; Paul E. Lovejoy and David Richardson, "Letters of the Old Calabar Slave Trade, 1760-1789," in Genius in Bondage: Literature of the Early Black Atlantic ed. Vincent Carretta and Phillip Gould, (Lexington: 2001)pp. 89-115; Randy J. Sparks, The Two Princes of Calabar: An Eighteenth-Century Atlantic Odyssey, (Cambridge, Mass.: 2004); Stephen D. Behrendt, A.J. Latham, and David Northrup, The Diary of Antera Duke: An Eighteenth-Century African Slave Trader (New York: Forthcoming); and Gomer Williams' chapter "The Massacre at Old Calabar" in Williams, Liverpool Privateers, . ${ }^{3}$ Ralph A. Austen and Jonathan Derrick, Middlemen of the Cameroons Rivers: The Duala and Their Hinterland, C.1600-C.1960, African Studies Series, (Cambridge; New York: 1999); Ralph A. Austen, "Slave Trade and Memory on the Periphery of the Nigerian Hinterland," in Ports of the Slave Trade (Bights of Benin and Biafra): Papers from a Conference of the Centre of Commonwealth Studies, ed. Robin Law and Silke Strickrodt, (Stirling: 1998); and Jean-Pierre Warnier, "Traite Sans Raids Au Cameroun", Cahiers d'Etudes Africaines, vol. 29, no. 113, (1989); are the only detailed studies of the Cameroon slave trade, with a heavy focus in each case on the nineteenth century. There are several studies on Cameroon's ivory trade, including Marion Johnson, "By Ship or by Camel: The Struggle for the Cameroons Ivory trade in the Nineteenth Century", Journal of African History, 19, 4 (1978), pp. 539-549.
} 
important exception. The "New" Davenport papers include a number of letters from his captains trading to the Cameroon River, shedding light on how the slave trade operated there. ${ }^{4}$ The "Old" Davenport papers also include "Trading Accounts" of Davenport's slaving voyages detailing assortments of European goods shipped to both Cameroon and Old Calabar. ${ }^{5}$

Using the detail available in the Davenport papers, we will see how William Davenport created specialist cargoes and merchant partnership formations based on the unique trading conditions at Old Calabar and Cameroon. Section one presents an overview of the Davenport's African trading pattern, showing how he came to focus his trade in the eastern Bight of Biafra. Section two details the assortments of goods demanded by Efik (Old Calabar) and Duala (Cameroon) consumers in exchange for slaves and ivory. In section three and four, we will see how Davenport organised the human and financial resources of his Liverpool merchant house to the unique African trading conditions at both markets.

In William Davenport's early career, his African trading pattern was dictated by his master William Whaley. For the first four years after his freedom, 1748- 1752, Davenport only invested in voyages managed by Whaley and, as a non-managing partner in the firm, he had no influence over the choice of African markets. Because so little is known about Whaley and the early Liverpool slave trade it is difficult to ascertain where he traded in Africa. However, we do know that by the late 1740s and 1750, when Davenport has joined the firm, Whaley had focused his trade on two locations: Old Calabar, in the Bight of Biafra, and Gambia, on the Upper Guinea Coast. $^{6}$

The Old Calabar and Gambia regions were very different slaving markets. At the Gambia small vessels purchased captives to be sold primarily to North American

\footnotetext{
${ }^{4}$ The letters are in the vory Book 1763-1785, Liverpool, D/DAV/1; "Badger's $3^{\text {rd }}$ Voyage 1774-1776", Liverpool, D/DAV/7; and "Papers Ship new Badger's inward acco 1777", Liverpool, D/DAV/10; "Essex and Christopher to Dominica," Liverpool, D/DAV/15

${ }^{5}$ Within the "Old" Davenport Papers there are accounts (with varying details) for thirty-seven Old Calabar and twenty-six Cameroon voyages. The "New' Davenport Papers contain a single additional Cameroon account for the Rover's 1782 voyage (Voyages Database 83413; "Trading Accounts of the Rover" in Ship Accounts 1768-1787, Liverpool, D/DAV/2).

${ }^{6}$ Based upon the ownership data in the Voyages Database
} 
rice and tobacco planters. ${ }^{7}$ At Old Calabar, two thousand miles further round the Guinea Coast, the slave trade was a high volume business, carried out by large vessels that shipped their enslaved cargoes principally to the West Indies. As a result, Gambia took more vessels, but exported fewer slaves than Calabar. In 1745-1765, for example, 144 slaving vessels embarked approximately 43,000 enslaved Africans from Calabar, an average of three hundred per vessel. At Gambia, 233 slaving vessels carried off 35,000 slaves in the same period, 150 per vessel. ${ }^{8}$

William Whaley fitted out ships for both Old Calabar and the Gambia in his capacity as "ship's husband" for his ventures. As the husband, he bore responsibility for procuring the cargo, arranging the instructions for the ship's captain, attracting investment to the venture, and settling the accounts and finances at the end of the voyage. ${ }^{9}$ Fitting out a vessel took between two and seven months, and the husband had to liaise with numerous suppliers, each of whom dealt in specific commodities. Taken together, these tasks represented a time consuming and difficult process, and required knowledge of the specific trading assortments desired at each individual African markets. Because of the specialist knowledge required to be a ship's husband they numbered just fifty-four men in 1753, out of a community of approximately two hundred slaving merchants. ${ }^{10}$ Within this large cohort existed a smaller "management elite," as Richardson described them, of specialized Africa merchants numbering just fourteen men, Whaley amongst them, that managed half of the town's slaving ventures. ${ }^{11}$

As Whaley's protégé, Davenport received training managing slaving vessels and, crucially, learned the trading assortments desired at Old Calabar and Gambia. In 1752, for example, he was "very busy assisting [Whaley] to fit out the Chesterfield

\footnotetext{
${ }^{7}$ Lorena S. Walsh, "Liverpool's Slave Trade to the Colonial Chesapeake: Slaving on the Periphery," in Liverpool and Transatlantic Slavery, ed. David Richardson, Suzanne Schwarz, and Anthony Tibbles, (Liverpool: 2007), pp.103-105

${ }^{8}$ Based on shipping and slave volumes documented in the Voyages Database

${ }^{9}$ David Richardson, "Profits in the Liverpool Slave Trade: The Accounts of William Davenport," in Liverpool, the African Slave Trade, and Abolition, ed. Roger Anstey and Paul Hair, (Liverpool: 1976), pp.67-68

${ }^{10}$ The largest slaving merchants at the time were Foster Cunliffe, George Campbell, John Knight, John Welch, Richard Gildart and William Whaley (Williamson, The Liverpool Memorandum Book, pp.14$15)$.

${ }^{11}$ For the period 1766-1774, David Richardson has estimated that just twenty merchants managed 70 percent of Liverpool's slaving voyages. The lack of growth within the ranks of the "management elite" implies that the knowledge needed to become a large slaving merchant was jealously guarded by its holders, and issued only to trusted associates and apprentices (Richardson, "The Accounts of William Davenport," p.68).
} 
[for Calabar] and Orrell [for Gambia] with all expedition."12 Davenport applied his experience of fitting out slaving vessels when he started his own company in 1753 and acted as the ship's husband for the Charming Nancy, the first time he had selected a cargo in his own name. ${ }^{13}$ After this foray into the Gambia, Davenport continued to press his investment in the region, and dispatched two more ships there in $1754 .{ }^{14}$

The Charming Nancy joined a shoal of Guineamen trading to Gambia. In 1752, twelve slavers had purchased slaves at the market; in 1754 that number grew to twenty-five. ${ }^{15}$ Davenport received reports from his captains that the Gambia had become glutted with slaving vessels. In January 1755, he complained to Charleston slaving factor Henry Laurens that he was afraid the slavers would "overdo that River" as "17 ships sail for that place." 16 Writing to a Bristol captain in June of that year, Laurens confirmed Davenport's complaints, informing him that

Our Accounts from Gambia are very bad, Slaves scarse, upward of 20 Sail in the River and the small pox currant among them, we believe few Slaves will come from that Quarter ${ }^{17}$

Davenport had further cause to complain about the Gambia market after he lost two experienced slaving captains. In 1756 Captain Isaac Hyde died on his passage back to Britain, causing a "great loss" to Davenport as "no one was better acquainted, or understood the trade in Gambia better than himself."18 Two years later Samuel Sacherverell, a veteran of four slaving voyages to Gambia in the Charming Nancy, died "soon after his arrival" in Liverpool. Sacherverell had made a poor voyage owing to the "number of ships in the River", and hence Davenport and his associates "put the vessel [Nancy] up for sale." 19

\footnotetext{
12 William Davenport to Davies Davenport, Liverpool, 31 December 1752, BDM

${ }^{13}$ Voyages Database 90478

${ }^{14}$ Voyages Database 90479 (Charming Nancy), 90552 (James)

${ }^{15}$ Based upon shipping volumes documented in the Voyages Database

${ }^{16}$ William Davenport to Henry Laurens, Liverpool, 28 January 1755, in Letter and Bill Book 17471761, ODAV

${ }^{17}$ Henry Laurens to John Knight, Charleston, 26 June 1755 in Donnan, Documents: Border \& Southern Colonies, p.321

${ }^{18}$ William Davenport to Captain Gilbert Rigby, Liverpool, 25 March 1756, in Letter and Bill Book 1747-1761, ODAV; In 1752, Whaley lost a Gambia captain when Samuel Lacer and his first mate, both of the Orrell (Voyages Database 90297) were "poisoned in the Gambia river by the King of Barra occasioned by some falling out they had with him" (William Davenport to Davies Davenport, Liverpool, 31 December 1752, BDM).

${ }^{19}$ William Davenport to Richard Evans, Liverpool, 10 April 1758, in Letter and Bill Book 1747-1761, ODAV
} 
The dire trading conditions at the Gambia forced Davenport to turn his gaze elsewhere on the Guinea Coast. From 1756 until 1764, Davenport invested in slavers to the Windward Coast, Malembo, Anomabu, Bassa and Bonny, whilst simultaneously maintaining an investment in the Old Calabar vessel Chesterfield. ${ }^{20}$ As part of this shifting pattern of investment, Davenport looked to Cameroon, a region just one hundred miles from Old Calabar, as a potential alternative to the glutted Gambia. Davenport had probably heard about Cameroon through his friend John Knight who received a letter from Henry Laurens in 1755 telling of a "Sloop of New York laden with Red Wood some Teeth and 30 Slaves" arriving in Charleston from Cameroon. ${ }^{21}$ In that same year another Guineaman (or perhaps the same one disposing of a portion of its cargo in the West Indies) sold a group of enslaved Africans from Cameroon in St. Kitts. These slaves, Davenport heard, were "esteemed a very fine sort" and, as a result, worth above $£ 26$ Sterling per head, slightly more than Gambia slaves. ${ }^{22}$

Apart from these rumours surrounding the Cameroon, the region remained terra incognita to the Liverpool merchant community as the waters from Fernando Po to Cape Lopez had not been explored systematically. Despite the Liverpool merchants' ignorance, other Europeans had been trading with the Duala people of the Cameroon since the seventeenth century. ${ }^{23}$ From their home of Douala, at the mouth of the Wouri, Dibamba and Mungo rivers, the Duala people had profited from frequent trade with the Dutch whose ivory vessels arrived in numbers from the mid 1600s. The Cameroon market remained an ivory export centre throughout the first half of the eighteenth century with Dutch vessels purchasing hundreds of tons of

\footnotetext{
${ }^{20}$ Based on the ownership data in the Voyages Database

${ }^{21}$ The New York vessel was the Polly, Captain Miller (Voyages Database 25375; Henry Laurens to John Knight, Charleston, 21 July 1755 in Donnan, Documents: Border \& Southern Colonies, p.326). ${ }^{22}$ William Davenport to Mr Bezeliel Hodge, Liverpool, 15 September 1756, in Letter and Bill Book 1747-1761, ODAV; William Davenport to Messrs Francis Delap \& John \& William Halliday, Liverpool, 24 February 1757, in Ibid.; For example, Davenport advised Captains Sacheverall, who traded to Gambia in 1754, that he could expect to sell his captives for $£ 24$ sterling per person (William Davenport to Samuel Sacheverall, Liverpool, 4 October 1754, in Ibid.,).

${ }^{23}$ The Portuguese had explored Fernando Po, a large island facing the mouth of the Cameroon River circa 1500. However, as Warnier states, "before 1600, European techniques in naval construction and navigation prevented them from accessing the Coast of Cameroon." After 1614, Dutch vessels regularly traded at Douala, and from 1650 a large and consistent trade was established (Warnier, "Slave Trade without Raids", p.8).
} 
"elephants teeth", but just a thousand African captives. ${ }^{24}$ As a result the Cameroon slave trade remained under developed until late in the eighteenth century.

Suspecting that the untapped Cameroon could provide cheap and abundant slaves and ivory, Davenport fitted out a vessel for the market in the summer of 1756. The Racoon, a tiny fifty-ton sloop with just ten crewmen, sailed in September 1756 under the command of Thomas Hughes, a captain with just one previous voyage to his name. ${ }^{25}$ Racoon followed Ferret, the first British slave ship for the Cameroon, dispatched by John Welch in November 1755, who was perhaps acting on the same intelligence as Davenport had received. ${ }^{26}$ Sending the Racoon was a calculated risk on Davenport's part. He did not know how the Duala would receive his unknown captain; there was every chance the ship could be cut off or return empty handed. ${ }^{27}$

Although the account books and letter of instruction for the Racoon are lost, we can piece together Hughes' orders from another of Davenport's pioneering ventures. In 1767 the King of Prussia, operating in combination with the Henry, went to scout out the potential markets of Cape Lopez, the River Nazareth and Gabonthree ports to the south of Cameroon. ${ }^{28}$ The investors in the voyage, Davenport amongst them, sent the brigantine Henry to São Tomé with a generic cargo of Africa goods. There, Captain Joseph White, sailing for the first time as captain, was to "procure a trader acquainted with Gaboon \& Nazareth" and exchange the Henry's goods for an assortment based on the local man's knowledge. ${ }^{29}$ Captain Samuel Richardson in the King of Prussia followed White to the coast in order to learn

\footnotetext{
${ }^{24}$ For a detailed account of the Duala's history see Austen and Derrick, Middlemen of the Cameroons Rivers, pp.26-31

${ }^{25}$ (Voyages Database 90652); Hughes' previous command had been in the Old Calabar sloop Tom, a thirty-eight ton vessel partially owned by Davenport (Voyages Database 90623).

${ }^{26}$ The Ferret displaced 110 tons and carried 148 enslaved Africans from the Cameroon (Voyages Database 90566). Her owners, John Welch \& Company, immediately dispatched her back to the Cameroon (Voyages Database 90567). However, after she was taken by the French, he quit the region. John Bury, the captain of the vessel, returned to the Cameroon trade as ship's husband for two voyages in 1762 and 1763, implying he possessed valuable knowledge of the market. Bury briefly remained in the Cameroon trade as a minor investor until 1769 (Voyages Database 90951, 90952).

${ }^{27}$ The partners in the Racoon's voyages were William Davenport, Thomas Marsden, John Perkins, John Maddock, and Edward Cropper. Cropper and Maddock had both invested previously invested in Davenport's Gambia ventures (based on the ownership data in the Voyages Database).

${ }^{28}$ The King of Prussia was a 182 ton snow commanded by Samuel Richardson (Voyages Database 91408). Her tender Henry was a smaller 128 ton snow commanded by Joseph White (Voyages Database 91082).

${ }^{29}$ Alexander Nottingham \& Co. to Captain Joseph White, Liverpool, 10 July 1767, in Trading Accounts of the Henry 1765-1767, ODAV
} 
exactly what trade goods these regions desired. ${ }^{30}$ Clearly this information was of some value to the other Liverpool slave traders, for Richardson was to

[Furnish] us with an abstract for your cargo...refer[ing] us to the Numbers of the goods according to the invoice as it will prevent any one from taking an advantage shoud they have the curiosity to open the letter, \& this ... is what several times has been done, especially by Letters from a part of the Coast so unknown as Nazareth \& Gaboon on which accot you cannot be too secret in your transactions. ${ }^{31}$

Given that Cameroon was also "unknown", coupled with Davenport requesting Hughes to send "an abstract for the Cameroon by the first opportunity" in one of two letters that survive about the Racoon's voyage, we can assume Hughes operated on the same scheme as Richardson and White: to explore the untapped Cameroon River and discover precisely what goods the Duala desired in exchange for their slaves. ${ }^{32}$

Hughes fulfilled his instructions by purchasing eighty-three slaves from the Duala and securing an "abstract" for the Cameroon. ${ }^{33}$ He was, however, intercepted on his passage to Saint Kitts by the French, who took Racoon, but let the captain and crew go free. ${ }^{34}$ After returning to Liverpool, Thomas Hughes was placed in command of the seventy-four ton brig Calveley, and ordered to the Cameroon in September 1757. ${ }^{35}$ Once again Hughes' vessel was captured by the French who took Calveley's sixty enslaved Africans, but let the ship go free. ${ }^{36}$ Despite this second setback, Davenport sent Hughes back to Cameroon in the Union, a much larger vessel of 182 tons. ${ }^{37}$ After fourteen months at sea, Davenport was greeted with the sight of the Union returning to port, the first of his Cameroon ventures to successfully complete their voyage.

\footnotetext{
${ }^{30}$ Thomas Staniforth \& Co. to Captain Samuel Richardson, Liverpool, 11 Oct. 1767, in Trading Accounts of the King of Prussia 1767-1779, ODAV

${ }^{31}$ Ibid.; The King of Prussia and Henry venture returned a negligible profit to the owners (see Appendix B), and therefore Davenport and Company sent no further vessels to the Gabon region.

${ }^{32}$ William Davenport to Captain Thomas Hughes, Liverpool, 24 February 1757, in Letter and Bill Book 1747-1761, ODAV

${ }^{33}$ Hughes must have learnt what the Duala desired because his cargo was correctly "assorted" for Cameroon on the Calveley's voyage (Trading Accounts of the Calveley 1759-1761, LRO, Liverpool, England).

${ }^{34}$ Hughes must have been released because he was back in Liverpool by September 1758 when he took command of the Calveley.

${ }^{35}$ Voyages Database 90745

${ }^{36}$ Williams, Liverpool Privateers, p.667

${ }^{37}$ Voyages Database 90905
} 
Despite his success in completing a Cameroon voyage, Davenport declined to send the Union back to the region until March $1764 .{ }^{38}$ Instead, Davenport continued to experiment with other slaving regions, each of which gave poor returns on his investment (which we discuss in detail in chapter three). Only the Dalrymple, the first Old Calabar vessel owned and managed by Davenport's company, proved a success. ${ }^{39}$ In 1765 Davenport thus took a momentous decision when, weighing up his future investment options, he elected to push his trade firmly into the Old Calabar and Cameroon markets (Figure 2).

Figure 2: William Davenport's Trading Pattern by African Region, 1748-1785 (£ invested)

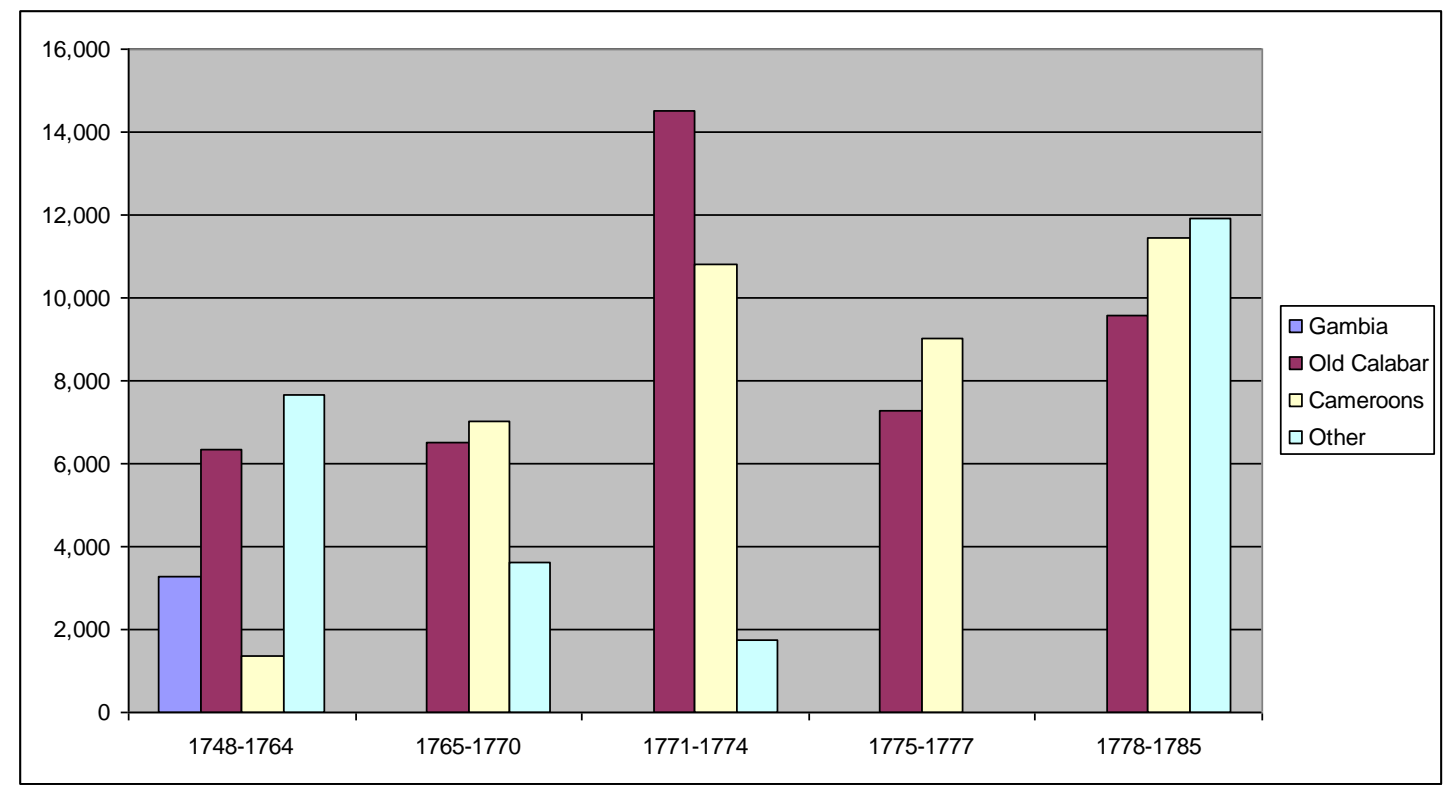

Sources: Ownership data from the Voyages Database; "Old" Davenport Papers; "New" Davenport Papers.

Note: "Other" is principally comprised of the Windward Coast, New Calabar, Bonny, and Benin.

For the next twenty years, Davenport was the only British merchant to invest in multiple ventures to Old Calabar and Cameroon simultaneously. From 1765 to 1785, Davenport held shares in two thirds of the Guineamen dispatched by slaving merchants-including those from other British and European ports-to Cameroon. Paralleling his Cameroon trading, Davenport possessed shares in a quarter of the

\footnotetext{
${ }^{38}$ Voyages Database 90906

${ }^{39}$ Voyages Database 91016
} 
vessels trading to Old Calabar in the same period-more than any other British slaving merchant. ${ }^{40}$ What makes Davenport remarkable is the fact that he managed to invest in both regions despite their marked dissimilarities. Because the Cameroon market was less developed, slaving merchants dispatched nearly two hundred fewer voyages to the region in the period 1756-1785: even in the peak years of Cameroon trade, 1770-1779, only a third as many Guineamen visited the region as they did Old Calabar. Cameroon vessels were also smaller, and carried fewer slaves than their Old Calabar counterparts. Cameroon was dwarfed by its neighbour as a slaving port, with the result that nearly five times as many enslaved Africans were carried from Calabar than Cameroon (Table 2).

Table 2: Old Calabar and Cameroon Slave Trades, 1756-1785

\begin{tabular}{|c|c|c|c|c|c|c|c|c|}
\hline \multirow[b]{2}{*}{ Period } & \multicolumn{2}{|c|}{ Voyages } & \multicolumn{2}{|c|}{ Enslaved Africans } & $\begin{array}{r}\text { A } \\
\text { Slaves }\end{array}$ & $\begin{array}{l}\text { rage } \\
\text { er voyage }\end{array}$ & \multicolumn{2}{|c|}{ Average tonnage } \\
\hline & Calabar & Cameroon & Calabar & Cameroon & Calabar & Cameroon & Calabar & \\
\hline $1756-1759$ & 17 & 4 & 6,120 & 680 & 360 & 170 & 132 & 59 \\
\hline $1760-1769$ & 108 & 21 & 32,312 & 3,743 & 299 & 178 & 128 & 84 \\
\hline $1770-1779$ & 104 & 37 & 26,287 & 9,512 & 253 & 257 & 117 & 99 \\
\hline $1780-1785$ & 38 & 13 & 12,691 & 3,475 & 334 & 267 & 167 & 108 \\
\hline Totals & 267 & 75 & 77,410 & 17,410 & 312 & 218 & 136 & 88 \\
\hline
\end{tabular}

Source: All data is derived from the Voyages Database.

Further, there were also significant differences in the goods assembled by Europeans to trade at Calabar and Cameroon. As David Richardson has shown, these "differences in West African consumption patterns appear to have had significant repercussions for the structure, organization and even profitability of English slave trading in the eighteenth century." 41 Examining precisely how these African consumption patterns differed will illustrate how the slave trade operated at the two ports. Moreover, by analysing consumption patterns we will see how Davenport overcame the region's differences and maintained his position as the eminent Liverpool slave trader in the eastern Bight of Biafra region.

\footnotetext{
${ }^{40}$ In the period $1765-1785$ there were sixty-one documented slaving voyages to Cameroon, of which Davenport held shares in forty-six. 207 slavers visited Old Calabar in the same period, of which Davenport invested in fifty (based on the ownership data in the Voyages Database).

${ }^{41}$ David Richardson, "West African Consumption Patterns and Their Influence on the EighteenthCentury English Slave Trade," in The Uncommon Market: Essays in the Economic History of the Atlantic Slave Trade, ed. H.A Gemery and Jan Hogendorn, (London: 1979), p.305
} 
As Davenport had learned under Whaley, the African middlemen of Calabar, the Efik, traded slaves primarily for luxury textiles imported from India, usually rolls and kerchiefs of checked cloth that could be fashioned into apparel. Finished goods, such as hats, jackets, and trousers, also featured in the mix of textiles, although to a lesser degree. The tiny percentage of textiles included in Cameroon cargoes, by contrast, consisted almost entirely of small quantities of cloth and finished outfits (Figure 3). Given the low value of textiles within Cameroon assortments, it is likely slaving captains gifted cloth to Duala merchants as a dash (gifts to win the favour of selected traders) but did not use them to purchase slaves or ivory directly. At Old Calabar, though, textiles formed one of the most important components of any slaver's cargo; captains who arrived with poorly assorted cargoes of cloth, or cloth in the wrong pattern or length, could expect difficult trade. Or as one Efik trader stated: if the "Indgey goods be Right good," slaving vessels would "no stand long" in the river, an important consideration in the pestilential Calabar region. ${ }^{42}$

To spotlight the textile trade to Old Calabar, consider the goods received by Efik trader Antera Duke for the fifty slaves he sold from June 1769 to January 1770. Antera sold twenty-two men, eighteen women, five boys and five girls to John Potter, captain of Davenport and partners' ship the Dobson. ${ }^{43}$ According to the Dobson's outfit, Potter bartered trading goods valued at approximately $£ 430$-yielding an average slave price of $£ 812 \mathrm{~s}$. By value, sixty percent of the trading goods Antera received were East India and Manchester textiles. These included Indian photaes, chintz, chelloes, romals, cushtaes, nicanees and bafts-all told, 280 pieces of these various Indian cottons cost Davenport and partners $£ 225$, and luxury chintz, chelloes and romals cost almost $£ 2$ each-a sailor's monthly wage. ${ }^{44}$

\footnotetext{
${ }^{42}$ Grandy King George to Ambrose Lace, undated Letters [c.1773], [Old Calabar], in Lovejoy and Richardson, "Letters of the Old Calabar Slave Trade," pp.106

${ }^{43}$ Voyages Database 91545

${ }^{44}$ Behrendt, Latham, and Northrup, Diary of Antera Duke, chapter two; Trading Accounts of the Dobson and Fox 1769-1771, ODAV
} 
Figure 3: Trading assortments carried by Davenport's slaving vessels at Old Calabar and Cameroon, 1757-1792 (by percentage of $£$ value)

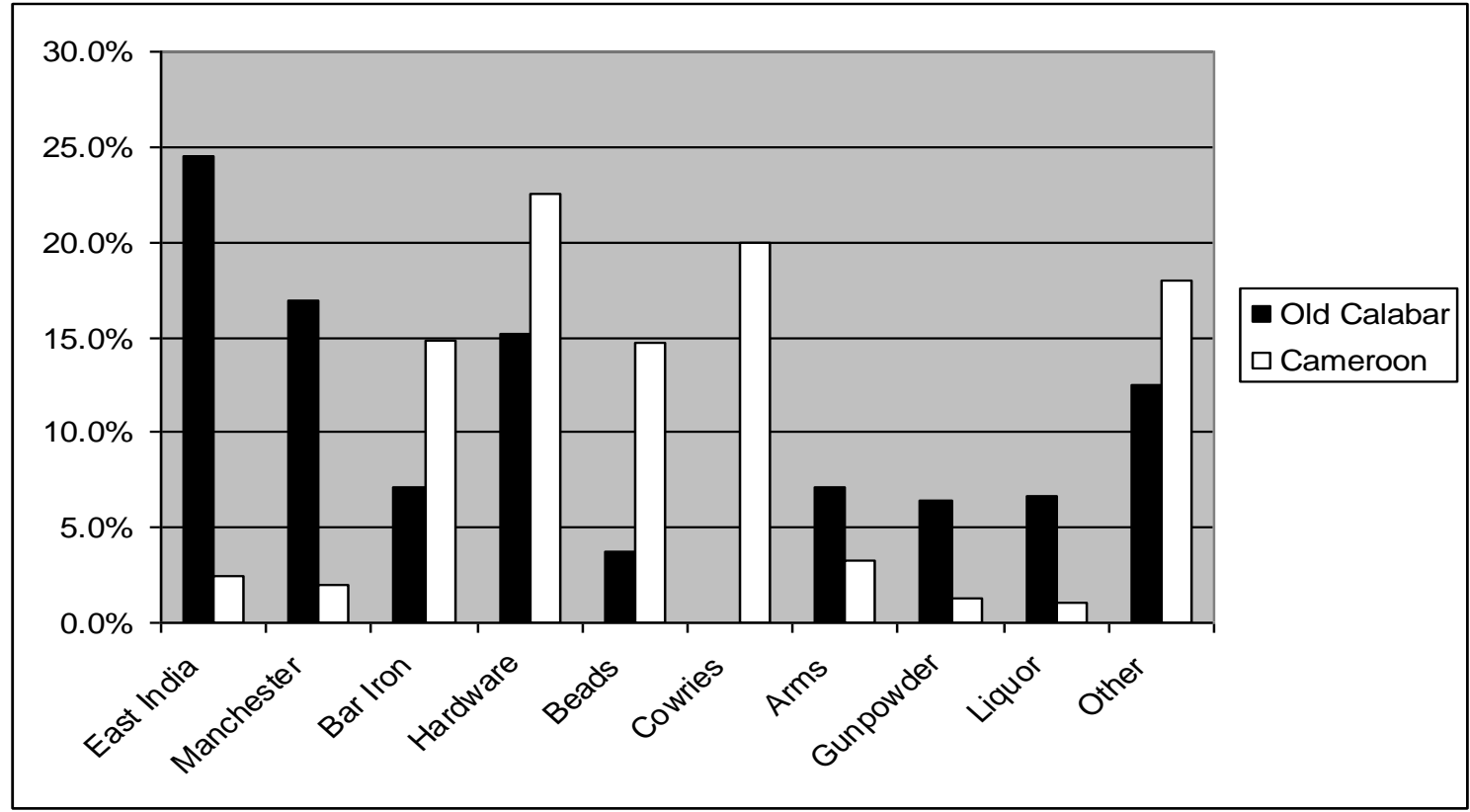

Note: 'Other' goods include rice, hawks' bells, salt, knives, fish, sugar, cups, bellows, earthenware.

Sample: Twenty-seven cargoes to Old Calabar; twenty cargoes to Cameroon

Source: Adapted from David Richardson, 'West African Consumption Patterns and their Influence on the Eighteenth Century English Slave Trade', in H.A. Gemery and J.S. Hogendorn (eds.), The Uncommon Market: Essays in the Economic History of the Atlantic Slave Trade, (New York, 1979), pp. 313-315.

Because of the critical importance of textiles at Old Calabar, Davenport's captains usually travelled to Manchester and London to select different fabrics of varying colour and cut. Experienced captains ordered and/or purchased textiles for at least thirty-four of thirty-seven Davenport ventures to Old Calabar. ${ }^{45}$ Some of these senior men were now merchants in their own right. Patrick Black, who sailed four times to Old Calabar in the Chesterfield between 1753 and 1758, acted as a key partner in Davenport's Old Calabar ventures by investing in twenty-seven voyages. ${ }^{46}$ Davenport utilised Black's knowledge of the Calabar trade by dispatching him to both London and Manchester, sometimes in the company of the ship's captain. Former

\footnotetext{
${ }^{45}$ The captain took no part in purchasing the cargo for the 1761 voyage of the Tyrell, William Hindle master (Voyages Database 90858), or in two voyages of the Dreadnaught, John Cooper master, in 1774 and 1776 (Voyages Database 91837, 91839). In all three instances the vessels carried a low value cargo; as a result, the partners may have purchased the textiles in conjunction with that of a larger vessel leaving in the same year (Trading Accounts of the Tyrell 1761-1762, ODAV; Trading Accounts of the Dreadnaught 1776-1777, ODAV; Trading Accounts of the Swift, Dreadnaught and Dalrymple, 1772-1777, ODAV).

${ }^{46}$ Voyages Database 90181, 90540, 90541, 90542
} 
captain Ambrose Lace, another of Davenport's key Calabar partners, also took a hand in selecting textiles. ${ }^{47}$

We see the importance of captains' textile knowledge from analysis of the Liverpool slaver Dalrymple's accounts, 1768-1777. In outfitting this ship to Old Calabar, Davenport sent his partners Patrick Black or Ambrose Lace and that year's Dalrymple captain to Manchester and/or London to choose and buy textiles. Travels to London generally totalled $£ 10-13$ per person — costs that included carriage transport and lodging near the East India warehouses. Twice, in 1768 and 1770, Patrick Black and the ship's captain travelled to London, and it is reasonable to suppose that Black instructed his protégés in how to negotiate with East India Company brokers and instructed captains on the best India textiles for the Calabar market (Table 3).

\section{Table 3: Captains' Journeys to Manchester and London to Purchase Textiles for Old Calabar, Liverpool Slaver Dalrymple, 1768-1777}

$\underline{\text { Date }}$ Davenport account entry

March 1768 P. Black \& Capt Allanson's Expenses to London £25.7.6 to buy the Cargo

March 1770 Pat Black \& Capt Fairweather to London £25.14.7;

A Lace Cash for London $£ 10.10$.

October 1772 Mr Black’s Expenses to Manch[este]r $£ 1.07$

Capt Fairweather Expenses to London $£ 12.12$

June 1773 Capt Fairweather's Expenses to London to Buy ye Cargo £12.12

June 1775 Capt Fairweather's Expenses to London $£ 10.10$

June 1777 Capt Fairweather's Expenses to London $£ 12.12$

Source: Trading Accounts of the Dalrymple 1766-1771, ODAV; Trading Accounts of the Swift, Dreadnaught and Dalrymple 1772-1777, ODAV

Whereas luxury Indian textiles comprised key trading goods at Old Calabar, merchants organizing Cameroon ventures assorted mostly hardware, cowries and beads that combined, totalled almost sixty percent of the cargo outlay by value. Of the hardware shipped to Cameroon, ninety percent by value was brass neptunes, a trading

\footnotetext{
${ }^{47}$ Trading Accounts of the Dalrymple 1766-1771, ODAV; Trading Accounts of the Quixote 17831785, ODAV
} 
good not demanded by Efik merchants (Figure 4). ${ }^{48}$ Africans used these large pansmeasuring 35-42 inches in diameter and weighing up to twelve pounds - to make solar salt or to clean butchered livestock. ${ }^{49}$ Given the large number of neptunes imported to Cameroon (each ship brought between five hundred to nine hundred pans) and the importance of salt in the Bight of Biafra region, it is likely that the Duala used neptunes for salt manufacture on a large scale. ${ }^{50}$ Brass rods constituted the remainder of the hardware imported by the Liverpool vessels. Each rod weighed either $10.75 \mathrm{oz}$ or $12 \mathrm{oz}$, making them slightly lighter than the manillas (copper bracelets or leglets) imported into other regions of Africa. ${ }^{51}$ The Duala seem to have taken brass rods in lieu of manillas, given that none of the vessels sampled carried the bracelets to the river, indicating they used brass rods for currency and manufacturing rather than as ornaments.

Metals shipped to Old Calabar were almost entirely copper rods, brass rods and manillas. Ship captains paid a quantity of copper rods as comey, port dues paid upon arrival at Calabar in return for a "license" to anchor and trade in the river. In addition, captains included copper rods in their assortments to purchase slaves and ivory. As Henry Schroeder (a.k.a. "William Butterworth") a mariner on the slave ship Hudibras, at Old Calabar in 1786, described:

The purchaser pays, in the first instance, with copper rods, about eighteen inches long and one inch in circumference, valued at about one shilling each. When the trader received the number of copper rods that he is entitled to, according to estimated value of the wretches he has trafficked away, he names the different articles he is in want of, for trade in the interior, such as gunpowder, calico, hardware, salt \&c. ${ }^{52}$

\footnotetext{
${ }^{48}$ Neptunes were also called "battery" because the pans were made by beating brass panels into shape.

${ }^{49}$ Davenport shipped fourteen tubs containing 700 "narrow brimd Neptunes" on board the Badger in 1772 (Trading Accounts of the Badger and Fox 1772-1778, ODAV). Their size implies that these were the large "Scottish Pans" as opposed to the smaller Spanish neptunes, which measured less than a foot in width (Stanley B. Alpern, "What Africans Got for Their Slaves: A Master List of European Trade Goods", History in Africa, vol. 22, (1995), pp. 15-16).

${ }^{50}$ An anonymous Liverpool slave ship surgeon who made four voyages to the Guinea coast in the 1770 s and 1780s recounted how salt was manufactured in his unpublished account: "[African women] bring the water from the beach, upon their head in kettles capable of holding two or three gallons: This they boil in large brass pans called neptunes until the aqueous particles are evaporated. What they thus procure may be considered as a course bay salt to refine which they reduce it into a powder," (Anon., "West Africa," (Unpublished: c.1784), pp.9-10).

${ }^{51}$ Brass rods were shipped in boxes, each box contained 125 rods. There were two sizes of rod, one weighed 94 lbs. per box, and the other 84 lbs. per box, making them the same weight as copper rods. Leg manillas, by contrast, weighed approximately $13 \mathrm{oz}$, and the smaller hand manilas $4 \mathrm{oz}$ (Trading Accounts of the Tyrell 1761-1762, ODAV; Trading Accounts of the Preston 1780-1784, ODAV).

${ }^{52}$ William Butterworth [Henry Schroeder], Three Years' Adventure of a Minor, (Leeds: 1822), p. 83
} 
Schroeder's account highlights the importance of copper rods to the slave trade at Old Calabar. Most ships carried 25-75 boxes, each containing 125 rods and thus totalling between 3,000 and 10,000 rods per voyage. Altogether, the rods comprised 10-15 percent of the total cargo (and 60 percent of the hardware) by value. However, the true value of copper rods at Old Calabar is greater, since the rods functioned as currency and were included in almost all barters. Davenport also shipped brass rods, between twenty and thirty percent of his hardware, in addition to small quantities of manilas. African smiths likely reworked brass and copper rods into tools or jewellery, and the rods also functioned as currency. ${ }^{53}$

\section{Figure 4: Metals Shipped to Old Calabar and Cameroon, 1750-1783 (by percentage of $£$ value)}

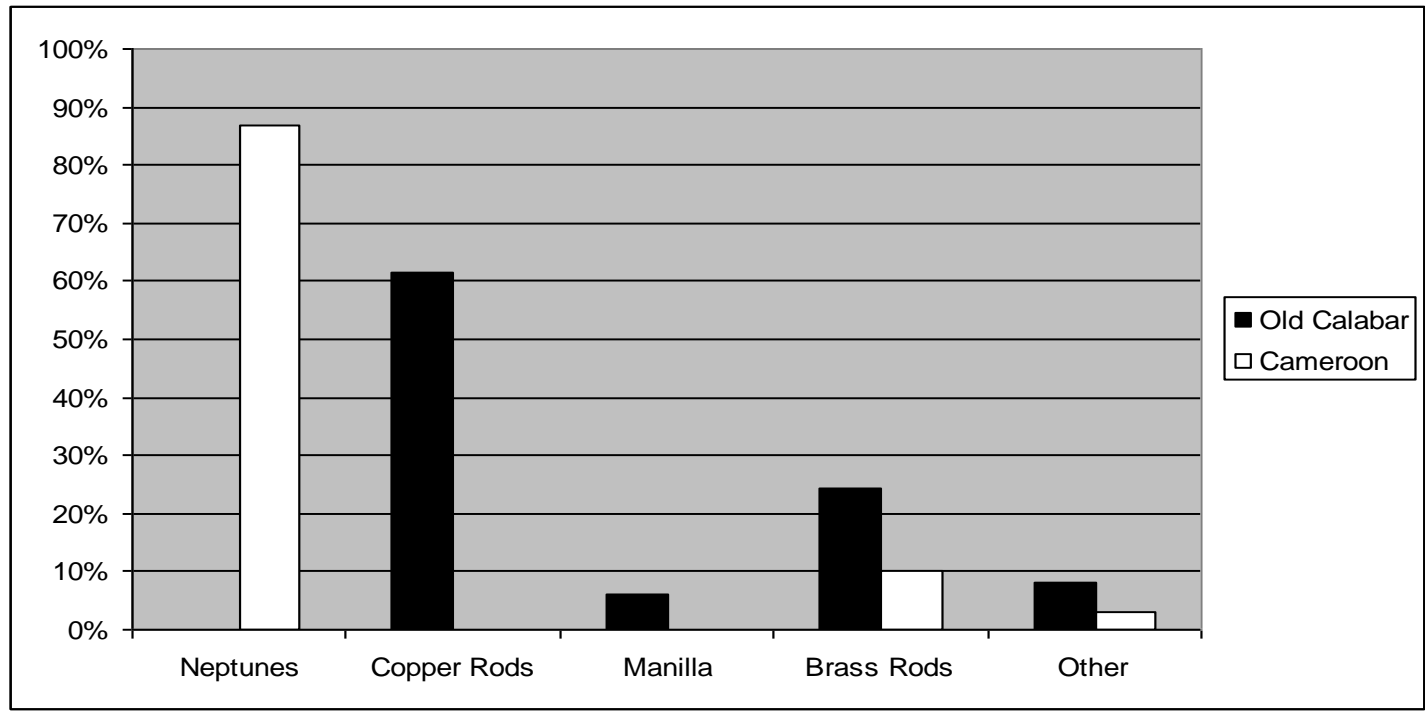

Sample: Twenty-seven cargoes to Old Calabar; twenty cargoes to Cameroon

Source: Trading Accounts for vessels destined to Old Calabar and the Cameroon, ODAV

Cowries (small sea shells imported from India) at Cameroon were as important as copper rods at Old Calabar. Captains paid for slaves with a combination of cowries and other trade goods, paying the small shells out in pint measures, with an approximate value of one and a half shillings sterling per pint. A series of letters from Peter Potter, captain of Davenport's Cameroon ship Bader, shows that between 1775

\footnotetext{
${ }^{53}$ For instance, when Antera Duke travelled from Duke Town to the west bank of the Cross River, he dashed Tom Curcock, a trader at Old Curcock Town, "four brass rods and a case of brandy". Later, east of Duke Town, Antera dashed "an iron rod and two copper rods" to Archibong Duke (Behrendt, Latham, and Northrup, Diary of Antera Duke, chapter four).
} 
and 1776, each slave was worth 70-125 pints of cowries, a sterling value of $£ 5.25$ $£ 9.40$, somewhat lower than slaves at Old Calabar. ${ }^{54}$ A captain purchasing slaves in the river relied heavily on his cowries; once his supplies of these small shells ran out, his trade in the river effectively ended, regardless of what other trade goods he still had on board. ${ }^{55}$ It was in the captain's best interest, then, to keep his cargo "well assorted" by not allowing his cowries to be depleted out of proportion from the rest of his trading goods.

Captains trading to Cameroon also traded for the region's abundant ivory. Ivory had the advantages that it stored well, took the place of potentially unruly slaves, and was available throughout the year. Cameroon in particular was

celebrated for its ivory, which is of a very superior quality, being less porous, and more free from flaws than that which is obtained [elsewhere on the Guinea Coast] ${ }^{56}$

Davenport's captains at Cameroon purchased ivory along with slaves, quantities and numbers depending on prices and individual barters. ${ }^{57}$ For example, in 1776 Captain Peter Potter had on board "81 slaves paid for and 3943 Lb Ivory" after three months in the river. ${ }^{58}$ Similarly, during Potter's 1775 voyage he had on board "16 slaves paid for \& twelve hundred [pounds] of Ivory" after two weeks in the river. ${ }^{59}$ Both these examples suggest that the purchase of ivory proceeded alongside the purchase of slaves, emphasising the Cameroon' importance as a port in the ivory trade.

We know from Potter's letters to Davenport that the assortment of goods traded for ivory varied from those traded for slaves at Cameroon. In August 1777, Potter sent a summary of the goods he had traded in exchange for 6,279 pounds of tusks. Potter's account indicates that neptunes and iron bars played an important part in the ivory trade, giving some explanation for their predominance in Cameroon

\footnotetext{
${ }^{54}$ Peter Potter to William Davenport, Cameroon, 23 June 1775, D/DAV/7; Peter Potter to William Davenport, Cameroon, 13 July 1775, D/DAV/7; Peter Potter to William Davenport, 15 October 1776, $\mathrm{D} / \mathrm{DAV} / 10$

${ }^{55}$ Peter Potter to William Davenport, Old Calabar, 23 July 1785, D/DAV/15

56 John Adams, Remarks on the Country Extending from Cape Palmas to the River Congo, (London: 1823), p.171

${ }^{57}$ Kenneth Morgan's research on the Bristol trade to Old Calabar, based on the Rogers' papers, suggests that in that market Bristol captains traded for ivory with "trade goods left after slaves had been purchased" (Kenneth Morgan, "James Rogers and the Bristol Slave Trade", Institute of Historical Research, vol. 76, no. 192, (May 2003), p.203).

${ }^{58}$ Peter Potter to William Davenport, Cameroon, 15 October 1776, D/DAV/10

${ }^{59}$ Peter Potter to William Davenport, Cameroon, 23 June 1775, D/DAV/7
} 
assortments (Table 4). Cowries, the main currency used for purchasing slaves, seem to have been seldom used, as Potter paid less than the price of one slave in cowries.

Table 4: Liverpool Slaving Ship Badger's Barter Transactions for 415 Slaves and 6,279lb of Ivory at Cameroon, 1777

\begin{tabular}{lrrrr} 
Type of Goods & \multicolumn{2}{c}{415 Slaves } & \multicolumn{2}{c}{$6,2791 \mathrm{lb}$ Ivory } \\
\hline Cowries & $£ 3457$ & $\mathbf{5 3 . 7 \%}$ & $£ 6$ & $1.4 \%$ \\
Hardware & 634 & $9.8 \%$ & 194 & $\mathbf{4 4 . 0} \%$ \\
Iron & 575 & $8.9 \%$ & 114 & $25.9 \%$ \\
Beads & 444 & $6.9 \%$ & 59 & $13.4 \%$ \\
Textiles & 253 & $3.9 \%$ & 16 & $3.6 \%$ \\
Arms & 158 & $2.5 \%$ & 0 & $0.0 \%$ \\
Gunpowder & 69 & $1.1 \%$ & 0 & $0.0 \%$ \\
Liquor & 34 & $0.5 \%$ & 0 & $0.0 \%$ \\
Miscellaneous & $820^{3}$ & $12.7 \%$ & $52^{4}$ & $11.8 \%$ \\
& $\mathbf{E 6 , 4 4 4}$ & $\mathbf{1 0 0 . 0} \%$ & $\mathbf{f 4 4 1}$ & $\mathbf{1 0 0 . 0} \%$
\end{tabular}

\footnotetext{
Notes: $\quad{ }^{1}$ approximately 340 tusks weighing about $18 \mathrm{lbs} /$ tusk

${ }^{2}$ neptunes (large brass basins) comprised $£ 679$ of the $£ 874$ outlay on hardware. Brass rods made up a further $£ 117$.

${ }^{3}$ miscellaneous goods traded for slaves included: rice, salt, tankards, knives, stockfish, chests, pease, and tobacco.

${ }^{4}$ miscellaneous goods traded for ivory include: "yellow bottles” (£18), "funnels" (£8), 101 dozen knives (£7), and salt (£6).
}

Sources: Peter Potter to William Davenport, "Account of Ivory Bought at the Cameroon in Exchange for Goods 1776” [ca. Sept 1776-Jan 1777], D/DAV/10

The assortment of bottles, funnels, knives, salt and clothing in Potter's ivory assortment appears irrelevant, given their low value. Both Potter and his later consort John Howard note in their letters that the trinkets, however, and particularly salt, were important trade items for ivory. Howard complained, for instance, about the loss of some salt from Potter's ship, which had been washed out by a leak: "I could have bought one ton more of ivory with that Salt." ${ }^{60}$ Moreover, when former (1790s) slaving ship captain John Adams listed the goods necessary to buy one ton of ivory at Cameroon in 1823, he included fifteen tons of salt and an assortment of minor cloths. Adams also noted "Guns, Gunpowder and Neptunes, and mock Coral [a type of bead],

${ }^{60}$ John Howard to William Davenport, Old Calabar, 4 November 1785, D/DAV/15 
always in great demand." ${ }^{, 61}$ It appears, then, that neptunes and salt remained crucial trade items in the Cameroon ivory trade throughout the late eighteenth and early nineteenth centuries.

The large quantities of ivory exported from Cameroon explain why the demands of Duala consumers differed from those of the Efik at Calabar. The ivory market required a very different mix of goods, one reliant on salt, neptunes and iron bars. Slaves, by contrast were paid for in the first instance with cowries, and then with a bundle of other goods - especially beads and metals. The less developed Cameroon slaving market provides an additional explanation for the differing consumer patterns in the two regions. At Old Calabar, European and Indian textiles comprised a small percentage of seventeenth century cargoes, as they instead purchased mostly copper rods and iron bars. Over the course of the eighteenth century, however, Efik traders gained market power and purchased broader assortments of high-quality consumer goods, including East Indian luxury textiles. ${ }^{62}$ Given that the 1760 s and 1770 s marked the formative period of the Cameroon slave trade, it is not surprising to find that they too desired small quantities of consumer goods, and instead sought items that could be traded as currency such as cowries, beads, and metal bars, or put to use in manufacturing, such as neptunes.

In 2007 Stephen Behrendt argued that differing African market conditions dictated in large part the type of men who officered slaving vessels. In particular, Behrendt emphasised the importance of captains in the 'ship trade' markets, such as Old Calabar and Cameroon, where experienced and knowledgeable officers formed "buyer-seller relationships" that "formed the nexus of cross-cultural trade" between Europeans and African. ${ }^{63}$ For a merchant such as Davenport seeking to capture market share in these regions securing the services of "captain princes" was critical. We can hence understand the differences between markets at Old Calabar and

\footnotetext{
${ }^{61}$ John Adams, Remarks on the Country Extending from Cape Palmas to the River Congo, (London: 1966), p. 251

${ }^{62}$ Behrendt, Latham, and Northrup, Diary of Antera Duke, chapter two; Similarly, Curtin found in his study of the Senegambia slave trade that between the 1680s and 1730s there was a marked move away from iron and bead imports towards textiles and firearms (Philip Curtin, Economic Change in Precolonial Africa: Senegambia in the Era of the Slave Trade, (Madison: 1975), p.318).

${ }^{63}$ Stephen D. Behrendt, "Human Capital in the British Slave Trade," in Liverpool and Transatlantic Slavery, ed. David Richardson, Suzanne Schwarz, and Anthony Tibbles, (Liverpool: 2007), p.67
} 
Cameroon further — seen before by analysing cargo assortments - by examining how Davenport chose ships and captains.

At Old Calabar, Davenport employed a ship and tender system that he had learnt in the Gambia trade during the $1750 \mathrm{~s} .{ }^{64}$ The factory vessel, commanded by an experienced captain and carrying a large cargo, purchased a sufficient number of slaves to fill the tender - a smaller accompanying craft. Once the tender was full it sailed for the Americas, leaving in the hands of the factory vessel its assortment of trade goods. The factory vessel then continued to slave in the river until it too was loaded. The system enabled a swift turn around for the tender; gave the factory vessel a large supply of trade goods; and reduced the mortality of the enslaved cargo, as African captives purchased shortly after the factory ship's arrival at Calabar would spend less time chained below deck, waiting for the vessel to be loaded. ${ }^{65}$

The ship and tender system had an additional advantage: inexperienced captains could be trained on board tenders in the manner of trade at Old Calabar. At Old Calabar the two-ship system paired a senior, experienced captain with his junior protégé—referred to by Efik trader Antera Duke as the captain's "tender." The age gradation between senior captain and junior "tender" mirrored Efik age sets, creating personal relationships that formed the nexus of trade at Old Calabar. ${ }^{66}$ A Cameroon captain, by contrast, almost always operated alone from single vessels. ${ }^{67}$ Given the lower number of slaves exported from Cameroon River, it is likely that the river did not necessitate the two ship system. As a result, the Cameroon took fewer vessels, and presented fewer opportunities for new captains to gain experience in the region.

Crucial to Davenport's "human capital" at Old Calabar was Patrick Fairweather, a young man in his twenties when he first sailed to the Cross River in the 1750 s who went on to become the senior ship captain, and honorary member of Efik

\footnotetext{
${ }^{64}$ Davenport had used the system when he combined the voyages of the Charming Nancy (Voyages Database 90480) and her tender James (Voyages Database 90552).

${ }^{65}$ Behrendt, Latham, and Northrup, Diary of Antera Duke, chapter two

${ }^{66} \mathrm{Ibid} /$

${ }^{67}$ An exception was when Liverpool vessels began to open up the Cameroon in the 1750s and 1760s. Then, a number of vessels went to the river in pairs in order to make use of the experience of the few captains who had visited the river. The Henry, for instance, appears to have acted as the tender to the larger vessels Union and King of Prussia throughout her five years trading at Cameroon. After 1769, the practice ceased and Cameroon vessels invariably sailed/traded as single ships (Trading Accounts of the Henry 1765-1767, ODAV; Trading Accounts of the Henry 1767-1769, ODAV; and Trading Accounts of the King of Prussia 1767-1779, ODAV).
} 
society by the 1780s. ${ }^{68}$ Fairweather probably joined Davenport's company in 1762 as second mate on the Dalrymple, captained by James Berry. ${ }^{69}$ After Berry's death on the Dalrymple's third voyage in 1765 , Fairweather received a promotion to first mate under Captain Alexander Allason. ${ }^{70}$ When Allason himself died during the Dalrymple's fifth voyage, Fairweather received command of the vessel, a position he held until $1777 .^{71}$

During Patrick Fairweather's tenure as the Dalrymple's captain he trained no less than six Calabar captains who later entered Davenport's employ. James Sharpe, William Seaton and John Sime each served as tenders to Fairweather before earning a command of their own Calabar factory vessels. ${ }^{72}$ Three other future commandersWilliam Brighouse, John Cooper and William Begg — served on board the Dalrymple itself, Brighouse and Cooper as mates, and Begg as a surgeon. ${ }^{73}$ This pool of captains sprung directly from James Berry, Davenport's first Calabar captain, through Allason and, most importantly, Patrick Fairweather, who became perhaps the most valuable asset in Davenport's Calabar firm. ${ }^{74}$

We can further explore the importance of human capital by examining how William Davenport organized merchant partnerships to trade for slaves and ivory at Old Calabar. Davenport's Old Calabar firm was remarkably stable during the period 1765-1777, the peak years of his Old Calabar trading. At the heart of the company

\footnotetext{
${ }^{68}$ For a detailed account of Fairweather's career see Behrendt, "Human Capital," pp.84-85. Patrick Fairweather is also mentioned in a brief study of his son Robert Fairweather, a Liverpool banker in the early nineteenth century (Hughes, Liverpool Banks \& Bankers, pp.220-222).

${ }^{69}$ We cannot know for certain when Fairweather first joined the Dalrymple because he doesn't appear in the Trading Accounts of the vessel until 1765. Behrendt suggests that Fairweather may have sailed "as a teenage apprentice on the Chesterfield captained by Patrick Black" in 1755 (Behrendt, "Human Capital," p.84; Voyages Database 90541).

${ }^{70}$ Trading Accounts of the Dalrymple 1766-1771, ODAV; Trading Accounts of the Swift, Dreadnaught and Dalrymple, 1772-1777, ODAV; Also the captain information in the Voyages Database

${ }^{71}$ Voyages Database 91220

72 John Sime aided Davenport further by training John Bailie. Bailie then went on to apprentice Thomas Cooper, who served Davenport for one voyage in 1784 (Voyages Database 91576, 83267).

${ }^{73}$ Trading Accounts of the Dalrymple 1766-1771, ODAV; Trading Accounts of the Swift, Dreadnaught and Dalrymple, 1772-1777, ODAV; Also the captain information in the Voyages Database

${ }^{74}$ When Davenport lost Fairweather to rival firm Tarleton \& Backhouse in 1778, he wound down his investment in the Old Calabar region. From 1778 until 1781 he held shares in just two Old Calabar vessels, one of which was the William, a produce vessel, and the other the Liverpool Hero (Voyages Database 82325). Davenport briefly returned to the region in 1783-1785 and invested in seven voyages, by which time he had to rely on former Cameroon captains John Smale and Peter Potter to command his vessels because so many Old Calabar captains had left his employ (Voyages Database 83063, 81312).
} 
was William Davenport and three former Calabar captains: William Earle, Patrick Black and Ambrose Lace. ${ }^{75}$

Earle, Black and Lace were ostensibly "sleeping partners", men who invested capital but took no part in outfitting the vessel. ${ }^{76}$ The Davenport accounts show, however, that the three men lent their experience and knowledge of the Old Calabar markets and therefore played an active part in the partnership. Crucially, they had established ties with Efik traders from the Old Calabar villages Creek Town, Duke Town and Old Town. A series of surviving letters show that a relationship clearly existed between Davenport and partners and Ephraim Robin John of Old Town; and Duke Abashy and Duke Ephraim of Duke Town. Ephraim Robin John, "Grandy King George," considered both Lace and Patrick Black to be "good" men, and in one letter to Lace passed on his regards to "Mr Devenport Marchant Black ... [and] allso $\mathrm{Mr}$ Erll". ${ }^{77}$ Robin John's detailed requests for goods that Efik desired also highlights the valuable trading intelligence that Lace possessed, and must have passed on to his partners. The relationship between Lace and Ephraim Robin John extended beyond trade, as Lace brought young Otto Ephraim Robin John to Liverpool, "and had him at School near two years, then sent him out [to Calabar;] he cost me above sixty pounds." ${ }^{78}$

William Earle also remained in contact with Efik merchants after his retirement as ship captain in 1752. Earle sent a letter to Duke Abashey of Old Town on 16 February 1761, clearly part of a frequent correspondence, assuring the Efik trader that he "loved all Calabar [and did] not want to wrong, nor I never did wrong any man one copper [rod]". Passing on news of the Earle family, he concluded with a message from his wife who "sends her love". ${ }^{79}$ Although no further letters from Efik merchants are extant, it is probable that Patrick Black also corresponded with men from Creek Town, Old Town or Duke Town, given his longstanding history with Old Calabar. There are no recorded instances of Davenport corresponding with the

\footnotetext{
${ }^{75}$ Of the thirty-nine Old Calabar ventures Davenport financed in the period 1765-1777, Ambrose Lace co-financed twenty-five, William Earle twenty-four, and Patrick Black eighteen. Earle had made two voyages to Calabar, Black four, and Lace three. Davenport's other Calabar traders in this period were John Parker, Robert Jennings and Edward Chaffers, each of whom co-financed between fifteen and twenty ventures (based on the ownership data in the Voyages Database).

${ }^{76}$ Richardson, "The Accounts of William Davenport," p.68

${ }^{77}$ Grandy King George to Ambrose Lace, undated Letters [c.1773], [Old Calabar], in Lovejoy and Richardson, "Letters of the Old Calabar Slave Trade," pp.106-107

${ }^{78}$ Ambrose Lace to Thomas Jones, Liverpool, 11 November 1773, in Ibid, p. 107

${ }^{79}$ William Earle to Duke Abashey, Liverpool, 16 February 1761 in William Earle's Letterbook, 23 Jan 1760- 23 Sept 1761, Earle Papers, MMM, Liverpool
} 
Calabar traders, but it is probable that he met some of the Efik men during their education in Liverpool. ${ }^{80}$ The Calabar traders certainly had the means to stay in contact with Davenport and his partners: Calabar assortments included writing implements, as in the Hector's outfit in 1776, which included letter books and journals, reams of foolscap paper, ink powder and quills. ${ }^{81}$

Davenport and his partners earmarked specific goods to win the favour of Calabar traders. On the ship Dobson, in 1767, Captain John Potter transported twelve brass basins engraved "Antera Duke"; in 1771 Creek Town merchant Willy Honesty received two coils of cordage addressed to him; the next year the Dalrymple loaded thirty basins inscribed "WH." ${ }^{\prime 2}$ Davenport and other British merchants also paid workmen to engrave Efik trade names on firearms, bells and canes. ${ }^{83}$ In European ports, workers likely loaded crates marked with the names or initials of Calabar businessmen; as Old Town merchant Ephraim Robin John stated to Ambrose Lace "Please to have my name put on Everything that you send for me." 84

Efik traders reciprocated by sending slave children and ivory tusks as gifts to the Liverpool merchants. In July 1773, Robin John Otto Ephraim of Old Town wrote to Lace that he had sent "Joshua 1 Little Boy By Captain Cooper" of the Dreadnaught and "one Boy By Captain Fairweather" of the Dalrymple. ${ }^{85}$ Not wanting the trouble of training the children as household servants, Lace had them sold in the West Indies. Robin John's mother also sent Lace's wife "one Teeth by Captain Sharp," 86 and in 1777, Lace received another tooth marked "AL" weighing $481 \mathrm{~b} .{ }^{87}$ Given their size, these ornaments must have been prized tusks, engraved with a greeting from the Efik traders and used as ornaments in Davenport and his partner's counting houses.

\footnotetext{
${ }^{80}$ Lovejoy and Richardson suggest that "Duke Abashey may have been to Liverpool" prior to 1760. If so, he probably met Davenport (Lovejoy and Richardson, "Letters of the Old Calabar Slave Trade," pp.94-95). Moreover, Robin John Otto Ephraim probably met Davenport during his education in Liverpool 1767-1769, as evinced by his father's salutation to "Devonport" in 1773 (Ibid., p.96).

${ }^{81}$ Trading Accounts of the Andromache and Hector 1769-1776, ODAV, f.170; Similarly, in 1771 the owners of the Lord Cassils loaded two boxes containing eight reams "Pot Paper" and "60 Books 1 Q: [quire] ea[ch] with Marble Covers," and the May shipped two reams writing paper, two books, four quires each, half-bound and lettered, and six books, three quires each, half-bound and lettered (Trading Accounts of the Lord Cassils and May 1771-1776, ODAV, f. 20).

82 Trading Accounts of the Dalrymple 1766-1771, ODAV, f.45

${ }^{83}$ Davenport and partners paid an engraver for "Cutting Names on 2 Guns" (Trading Accounts of the Lord Cassils and May 1771-1776, ODAV, f.6). For silver canes, see Lovejoy and Richardson, "Letters of the Old Calabar Slave Trade," p. 103.

${ }^{84}$ Grandy King George to Ambrose Lace, Undated [c.1773], Old Calabar, in Ibid. p.106

${ }^{85}$ Robin John Otto Ephraim to Ambrose Lace, Old Calabar, 19 July 1773, in Ibid., p. 105

86 Ibid.

${ }^{87}$ Captain William Brighouse to William Davenport, Barbados, 23 March 1777, D/DAV/11
} 
The Efik letters show precisely why Davenport, Earle, Black, and Lace all invested so heavily and consistently in Old Calabar: their personal relationships with Efik enabled them to dispatch vessels properly assorted with goods in demand in the Cross River Region. Such commercial information gave the firm of Davenport and Company a competitive advantage in the Old Calabar market, enabling them to entrench their position there.

Davenport's Cameroon partnerships, though also dominated by a small core of investors, included different combinations of traders but few captains. From 1765 to 1785, almost every voyage to Cameroon was financed by a group of just ten closely tied Liverpool merchants (Table 5). William Davenport, Alexander Nottingham, and Thomas Staniforth co-ordinated this small cohort by acting as ship's husbands for the Cameroon ventures. ${ }^{88}$

Nottingham began trading at the Cameroon independently of Davenport when, in 1763, he bought a share in the Henry, commanded by Samuel Richardson. ${ }^{89}$ The venture was Nottingham's first as a slaving merchant, probably because at twenty-six years of age he had only recently completed an apprenticeship. Nottingham did not manage the vessel until its third voyage in 1765, when Davenport bought into the venture, at which point the two men must have come to some agreement to combine their resources and exploit the Cameroon because, from 1765 onwards Nottingham and Davenport never parted their investments in the region. ${ }^{90}$

Thomas Staniforth came to the Cameroon trade after flitting between various slaving regions. After finishing his seven year apprenticeship with his father-in-law Charles Goore, a slaving merchant from 1749 until 1757, Staniforth invested in Guineamen trading to Angola, the Windward Coast, Sierra Leone, the Gold Coast and Benin. ${ }^{91}$ In 1768 he made his first investment in the Cameroon when he fitted out and managed the King of Prussia in partnership with Davenport and Alexander Nottingham. Staniforth's knowledge of Cameroon could not have been particularly great because he had not invested there before. However, his ship went on a "joint

\footnotetext{
${ }^{88}$ Ship accounts list the vessels' husband either by referring to the name of the company (for example, William Davenport \& Co.), or by the member of the partnership who made the "disbursements" (cash purchases) of the cargo.

${ }^{89}$ Voyages Database 91079

${ }^{90}$ Based on the ownership information in the Voyages Database

91 Ibid.
} 
venture" with the Henry in which "each owner of [the] vessel is equally concerned in both," and experienced captain Samuel Richardson took the helm of the King of Prussia $^{92}$ As investors in the King of Prussia venture, Davenport and Nottingham must have inducted Staniforth into their small clique of merchants because the three men formed a small group that dominated the slave trade at Cameroon until the end of the American War.

\section{Table 5: William Davenport's Merchant Partners in the Cameroon Region, 1765-1785}

$\begin{array}{lrr} & \text { Investments } & \text { As Manager } \\ \text { Davenport, William } & 45 & 20 \\ \text { Staniforth, Thomas } & 21 & 10 \\ \text { Doran, Felix } & 20 & 0 \\ \text { Martin, Charles } & 20 & 0 \\ \text { Nottingham, Alex } & 20 & 11 \\ \text { Pole, William } & 20 & 0 \\ \text { Taylor, Joseph } & 20 & 0 \\ \text { Case, Thomas } & 17 & 0 \\ \text { Watts, George Warren } & 17 & 0 \\ \text { Case, Clayton } & 16 & 0 \\ \text { Hughes, Thomas* } & 15 & 0 \\ \text { Middleton, Richard } & 11 & 0 \\ \quad \text { * Former Cameroon captain } & & \end{array}$

Sample: Davenport's partners who invested in ten or more Cameroon ventures.

Source: Based on the ownership data in Voyages Database

Note: Three ventures were managed by Thomas \& William Earle Junior, and one by John Copeland. All of these ventures occurred in the period 1779-1785.

As the ship's husbands of the Cameroon ventures, Davenport, Staniforth and Nottingham brought other partners into the market on the basis of friendship or previous business connections. Based on the ownership records, Nottingham brought Felix Doran, Charles Martin, and Joseph Taylor to the firm; Davenport added Thomas Hughes, George Warren Watts and William Pole to the trade; ${ }^{93}$ and Thomas

\footnotetext{
92 Thomas Staniforth \& Co. to Captain Samuel Richardson, Liverpool, 11 October 1767, in Trading Accounts of the King of Prussia 1767-1779, ODAV

${ }^{93}$ George Warren Watts was Davenport's neighbour on Drury Lane, and seems to have operated a large insurance office (Ledger Book 1763-1775, Liverpool, ODAV, f.14). It is not clear what Davenport's connection with William Pole was, but he was clearly an important member of Liverpool's elite. Brooke writes that Pole was "Mayor in $1778 \ldots$ and [held] the office of stamp distributor for Liverpool" (Brooke, Liverpool as It Was, pp.295-296).
} 
Staniforth consistently invested alongside Thomas and Clayton Case. ${ }^{94}$ There is nothing in the ownership patterns of these men to suggest that they were anything more than minor speculators in the Liverpool slave trade and appear instead, to have simply been friends of the three "gate-keepers" of the Cameroon region: Davenport, Nottingham and Staniforth.

The Davenport group controlled a small pool of experienced Cameroon captains, that began with Samuel Richardson and Thomas Hughes, the two pioneering slaving captains in the region. Hughes made ten voyages to Cameroon between 1757 and 1770, including the first in the Racoon, during which time he trained John Peers and John Eccles as captains. ${ }^{95}$ Peers' first mate on the Badger, Peter Potter, went on to become Davenport's key Cameroon captain throughout the American War. Samuel Richardson commanded seven voyages to Cameroon and trained Joseph White, John Hollingsworth and John Smale as captains. ${ }^{96}$ By rewarding these men with commands of their own ships, Davenport and his small group of partners kept a tight reign on Cameroon, successfully preventing any of their captains from joining other slaving firms who had an eye to pushing into the region. ${ }^{97}$

Of the Cameroon captains, only Thomas Hughes joined Davenport's firm as an established slaving merchant. It is possible that Hughes engendered the same relationship with the Duala people that Lace enjoyed with the Efik. In addition, Hughes probably consulted with Davenport on the assortments desired at Cameroon. This would explain his longevity in the Cameroon trade, and the leading position that Davenport, with whom he invariably invested, enjoyed in that market. Apart from Hughes, only three other Cameroon captains subsequently invested there: John Bury, who co-financed six voyages, acting as husband for two; John Smale, who held shares in five ventures, but never managed any; and Thomas Rymer, who husbanded five voyages from 1771 until $1775 .{ }^{98}$ Calabar surgeon and captain William Begg invested

\footnotetext{
${ }^{94}$ Based on the ownership information in the Voyages Database

${ }^{95}$ Based on the captains information in the Voyages Database

${ }^{96}$ Based on the ownership information in the Voyages Database and the Cameroon Trading Accounts in the Davenport papers

${ }^{97}$ A single exception was Captain John Eccles who commanded Davenport's ship William to Cameroon 1767-1770 (Voyages Database: 91214, 91215, 91585), before attempting to form his own Cameroon firm in October 1772. Eccles died in command of the firm's only ship Peggy in 1772 (Voyages Database: 91810), ending any hope of challenging Davenport's stranglehold on the region.

${ }^{98}$ Based on the ownership data in the Voyages Database
} 
in Cameroon with the firm Gregson, Case \& Aspinall from 1785 to 1792, but had never visited the estuary. ${ }^{99}$

Few Cameroon captains became resident ship-owners because Liverpool merchants did not utilize their connections to the Duala. In contrast to the outfitting records for Davenport's Calabar ventures, those to the Cameroon give no evidence of close personal trading relationships between Britons and Duala. The absence of writing implements from all extant trading assortments outfitted for Cameroon tells us that the Duala did not correspond with Liverpool merchants via captains. ${ }^{100}$ Neither did Duala traders receive specific trading goods, engraved or labelled for their own use; no single Duala trader is mentioned in the Davenport accounts. As such, it is likely that the Duala did not develop relationships with the Liverpool traders through experienced Cameroon captains.

If Davenport did not maintain ties with individual Duala merchants, how did he maintain his market share at Cameroon? To answer this question we must examine his other business concerns.

In 1766, Davenport established a bead company in partnership with Peter Holme, Thomas Hodgson, the Earle brothers Ralph, Thomas, and William, and John Copeland. The partnership combined Davenport, William Earle and Copeland's experience in the Guinea trade with Livorno residents Thomas Earle and Thomas Hodgson's connections to the Mediterranean bead market. Each of the partners were "Gentlemen of property", with substantial business concerns in Liverpool and numerous investments in the slave trade. ${ }^{101}$ Davenport seems to have been the instigator of the bead company project as he "was appointed the manager, and bookeeper for the Bead Company, and he kept the books ... and paid, and received all the moneys, and did employ Jos[eph] Wimpey of London Banker for the Company."102 Moreover, Davenport's "large Credit with Wimpey supported the

\footnotetext{
${ }^{99}$ Begg possessed experience as an African produce trader after commanding Davenport's brig William, which traded for ivory and palm oil at Old Calabar in 1780-1781. It may be that he applied his knowledge of the produce trade to the ivory rich Cameroon market. See chapter three for further information on Davenport's produce trading.

${ }^{100}$ Based on an analysis of the outfitting records in the Trading Accounts for Davenport's Cameroon ventures.

${ }^{101}$ William Davenport to Charles Ford, Liverpool, 23 March 1779, D/DAV/1

102 “A Case No. 5", Liverpool, 21 January 1791, 920CHA/10/9, in Edward Chaffers papers, MMM, Liverpool, England
} 
Credit of the Company." 103 Using their Mediterranean trading vessel Polly, the firm imported beads and cowries, and supplied both the partner's vessels and those of the other Liverpool slavers. ${ }^{104}$

Establishing the bead company was a remarkable piece of enterprise on the part of Davenport, made in response to changes in the structure of the Liverpool slave trade. Prior to 1766 Liverpool slaving merchants had sourced much of their trading cargo, including beads, from Holland, and shipped them to the Isle of Man for collection by outgoing Guineamen. The Isle of Man enjoyed tax-free status under the feudal right granted to the Dukes of Atholl, the "Lords of Man", allowing Liverpool merchants to circumvent the often prohibitory customs imposed on foreign goods by the mercantilist British Parliament. As Kenneth Morgan has noted, "The scale of the trade was substantial" with Dutch vessels bringing "goods valued at nearly $£ 224,000$ to the Isle of Man" between 1718 and 1764. ${ }^{105}$ This lucrative commerce ended in 1765 when the British Government incorporated the island into the British customs system with the passage of the Isle of Man Purchase Act. ${ }^{106}$

Davenport seized the opportunity to bring beads directly to Liverpool and established the bead company in July 1766. The articles of partnership declared the company would "[carry] on the Business or Trade of Vending and disposing of Beads, Arrangoes, Cowries, Corral," and that the "company stock... shall be upwards of ten thousand pounds but not to exceed the sum of twenty thousand pounds." 107 As start up capital, each of the seven partners paid $£ 331$, providing $£ 2,317$ in cash to purchase stocks of beads. ${ }^{108}$ However, the main finance for the bead company came from the wider Liverpool merchant community who lent $£ 24,350$ to the company in the first three years of its operation, at an interest rate of 4.5 percent. ${ }^{109}$ The ready availability of money "on bond" indicates that Liverpool's merchants possessed ample capital to invest in local ventures, of which Davenport and his associates took full advantage.

\footnotetext{
${ }^{103}$ William Davenport to Edward Chaffers, Liverpool, 27 June 1790, 920CHA/10/9, in Edward Chaffers papers, MMM, Liverpool, England

104 “Owners Polly 1768-1769” in Ship Accounts 1768-1787, Liverpool, D/DAV/2; Bead Cash Book 1766-1776, Liverpool, D/DAV/2; Beads Ledger 1766-1770, Liverpool, ODAV

${ }_{105}$ Morgan, "Liverpool's Dominance in the British Slave Trade, 1740-1807," p.21

106 The Isle of Man purchase act is also known as "Revestment." (Geo 3, cap 26)

107 "Articles of Partnership, 1766 re. selling of beads, arrangoes etc" in Earle Papers, MMM, Liverpool; Bead Cash Book 1766-1776, Liverpool, D/DAV/2

${ }_{108}$ Bead Cash Book 1766-1776, Liverpool, D/DAV/2, f.1

109 The loans are notified throughout the Bead Cash Book 1766-1776, Liverpool, D/DAV/2, including the frequent interest payments made by the company.
} 
With substantial financial backing, the company rapidly expanded, and by 1770 had vended $£ 39,048$ worth of beads to Liverpool slaving ships. ${ }^{110}$

The establishment of Davenport's bead company coincided with his specialization in the Cameroon market. With a reliable and steady supply of beads and cowries - two items that formed from a third to a half of the total cargo by valueDavenport could fit out Cameroon vessels supplied by his own company. As a result, Davenport massively increased his investment in the Cameroon region. Prior to 1766 Davenport had dispatched four small experimental vessels to the Cameroon, costing him in total just $£ 1,372$. From 1766 onwards Davenport invested in, on average, three vessels per annum to the region; an outlay on his part of $£ 25,699$ in the period 1766 1777. ${ }^{111}$

In addition to his bead concern, Davenport supplied substantial quantities of iron bars and hoops to his Cameroon vessels. He imported iron bars from Germany, Scandinavia and London, and iron hoops, for the manufacture of barrels, from London. ${ }^{112}$ Davenport supplied bars to slaving firms outfitting to all regions in Africa, as well as to his own vessels trading at Old Calabar and Cameroon. ${ }^{113}$ The iron hoops were primarily sold to his own ships, but also to Thomas Huntington, a cooper who supplied Davenport's vessels with finished barrels and hogsheads. ${ }^{114}$

Davenport maximised the efficiency of his Africa company further by buying and selling ivory, sourced mostly from Cameroon. Davenport operated an ivory trading company that bought approximately four tons of ivory per annum and resold it to a network of customers throughout England, Scotland, and Ireland. Using his network of contacts Davenport could quickly and efficiently dispose of the large quantities of ivory brought back to Liverpool by his Cameroon and Old Calabar vessels. In this way, Davenport's ivory dealings acted as valuable link in his Bight of Biafra business chain. ${ }^{115}$

\footnotetext{
${ }^{110}$ Account Book for Beads and Cowries 1766-1770, Liverpool, ODAV, f.153

${ }^{111}$ Based on the Trading Accounts for Davenport's Cameroon ventures, the estimates of Davenport's capital expenditure made in chapter one, and the ownership information in the Voyages Database.

${ }^{112}$ Waste Book 1766-1780, Liverpool, D/DAV/2

113 Ibid.

114 "Iron Hoops Bought and Sold 1768-1777", in Ivory Book 1763-1785, Liverpool D/DAV/1, ff.6870; Thomas Huntington was described as a "cooper and victualler" in 1777 (Gore, Gore's Liverpool Directory for the Year 1777, p.44).

${ }^{115}$ We discuss Davenport's ivory business in detail in chapter three.
} 
To illustrate how Davenport operated his Cameroon concern, consider the voyage of the Henry in $1769 .{ }^{116}$ Davenport took a one eighth share in the voyage alongside his usual cohort of Cameroon partners: the Case brothers, Thomas and Clayton; Felix Doran; William Taylor; Thomas Staniforth; Charles Martin; William Pole; George Warren Watts; and Alexander Nottingham, the ship's husband for the voyage. Davenport supplied $£ 723$ of the vessel's $£ 1,911$ cargo: beads, cowries, ironware and brandy-items making up forty percent of the cargo by value. At the completion of the Henry's voyage, Davenport also purchased the vessel's $£ 166$ of ivory, later to be on sold to his customers.

The Henry's voyage demonstrates the highly specialised supply chain that Davenport had developed for the Cameroon market. Through his bead company and iron concern, Davenport could supply three trade goods that comprised up to a half of the cargo at the Cameroon market: beads, cowries and iron bars. It follows, therefore, that Davenport became such a large investor in the Cameroon market because he had geared his other business concerns towards that trade. At the same time, though, Davenport's other businesses did not lend themselves well to the Old Calabar trade. Davenport supplied his Old Calabar vessels with iron bars, hoops and the small quantities of beads desired by that market; together they formed just ten percent of the cargo by value. Furthermore, Davenport made little effort to try and supply high demand Calabar goods such as copper rods to his vessels. Davenport even abandoned his wine business in 1773, through which he had formally supplied liquor to Calabar vessels (see chapter three). It is curious, then, that Davenport moved away from integrating his Calabar supply chain, just as he began specializing in the Cameroon market.

Perhaps other slaving trading merchants, operating like Davenport, controlled the supply of high-demand Calabar goods. ${ }^{117}$ The slaving firms Brown, Birch \& Leay and Clowes \& Harding, both operated by friends of Davenport, supplied brass and copper rods to the majority of Davenport's vessels. Similarly, the Warrington Copper \& Brass Company, in which William Boats invested, supplied metals to numerous Bonny ventures, and a number of Davenport's Calabar ships. William James, also

\footnotetext{
${ }^{116}$ Voyages Database 91083; The following is based on the Trading Accounts of the Henry 1767-1769, ODAV

${ }^{117}$ The following is based upon an analysis of suppliers in the Trading Accounts of thirty of Davenport's Old Calabar ventures.
} 
sold large quantities of brass neptunes to Davenport. ${ }^{118}$ Even Manchester's textile merchants possessed shares in slaving vessels. Charles Ford and Folliot Powell both invested in the Liverpool slave trade whilst simultaneously supplying Davenport's Manchester goods. ${ }^{119}$ It appears, then, that Davenport could not develop the same vertically integrated company for his Calabar ventures as he could at Cameroonother Lancashire merchants had already captured markets for key trading goods, such as textiles and copper, demanded in the Cross River Region.

The organizational advantage of Davenport's Old Calabar ventures lay not in an efficient supply chain, like he possessed for his Cameroon trades, but in the select group of experienced captain and merchant investors, with their developed ties to the Efik traders who consistently invested alongside him. Whilst less tangible, these personal links clearly benefited Davenport's company because he managed to remain the pre-eminent Liverpool slaving merchant in the Cross River Region for a generation. Moreover, he maintained market share throughout the wartime period, and in a region that, each year, required outfitters to organize varied assortments of trading goods based on the changing desires of Efik consumers. His investors at Cameroon, by contrast, included mostly men who could bring capital, but little else, to the organisation. In a market where connections to the African traders mattered less than the ability to maintain a consistent supply of trade goods, this structure seems to have worked perfectly well. Thus, it is clear how William Davenport could operate successfully in two diverse African markets. By specialising each arm of his firm according to African market realities, Davenport ensured that he held a competitive advantage in both regions.

Focusing on Davenport's marketing strategies at Old Calabar and Cameroon has illuminated how he managed his slaving business, enabling him to become one of Liverpool's largest Guinea merchants. Crucial to Davenport's success was his enterprise. In shifting away from the Gambia, and into the Old Calabar market, Davenport showed a willingness to adapt to changes in the structure of the African slave trade. Moreover, by opening up Cameroon to the slave trade, Davenport was

\footnotetext{
118 Based on the Trading Accounts of Davenport's Cameroon ventures.

${ }^{119}$ Folliot Powell invested in fourteen slaving ventures between 1765 and 1783. Charles Ford was a much larger investor and took shares in thirty ventures from 1760 until 1772. He appears to have been linked to William James as the two men frequently invested alongside each other (based on the ownership information in the Voyages Database).
} 
able to gain an early advantage in the region, allowing him to monopolize the employment of captains, and the supply of the goods needed to trade there. As part of this strategy Davenport established his bead company, taking full advantage of a unique change in the British customs system, and making Liverpool a centre of the bead trade. How Davenport financially profited from these changes he wrought in the Liverpool slave trade will be explored in the next chapter. 


\section{Chapter 3: William Davenport's Business Profits}

We saw in the previous chapter how William Davenport organised his merchant house to suit two unique African markets. Constructing this highly specialised company was a complicated and time consuming task: fitting out ships, and cultivating business associates, captains, African middlemen, and suppliers required commitment from Davenport at the expense of marriage and politics. Financial profit drove Davenport to devote himself entirely to business; after all, he had come to Liverpool as a young man to "make his fortune." Davenport was clearly successful in this endeavour. Upon his death bed he held a fortune of $£ 34,000$, making him one of Liverpool's richest slaving merchants. Was the slave trade, though, the root of his prosperity?

We can trace the slave trade's contribution to Davenport's wealth by examining a range of information contained in the Old and New Davenport Papers. Davenport kept detailed records for each aspect of his businesses. In particular, he recorded his slaving ventures in ship accounts, and ledger books, using double-entry bookkeeping with debit and credit columns to calculate his profits. ${ }^{1}$ For his other businesses, Davenport kept accounts of his purchases and sales of goods such as ivory, beads, and wine in his waste books and ledgers. ${ }^{2}$ Most of these records are extant in the Davenport papers allowing us to calculate his profits from a variety of concerns, an exercise performed by no other historian.

This chapter will determine William Davenport's profits in his range of business ventures and demonstrate how he maintained liquidity over a forty-year career that bridged two major European/Atlantic wars and several credit crises. We will begin our analysis by examining how Davenport financially organised his company, identifying how and why he blended his slaving and non-slaving businesses. We will then calculate Davenport's slave trading profits using a large sample of his ventures, analysing his returns by time period and African region. In the third section, we will consider Davenport's non-slaving profits, including his speculation in financial instruments. Finally, we will ask which of the three ventures

\footnotetext{
${ }^{1}$ Ledger Book 1763-1775, Liverpool, ODAV; Ledger Book 1788-1797, Liverpool, ODAV

${ }^{2}$ Personal Ledger 1763-1772, Liverpool, D/DAV/2; Bead Cash Book 1766-1776, Liverpool, D/DAV/2; Waste Book 1766-1780, Liverpool, D/DAV/2; Ivory Book 1763-1785, Liverpool, D/DAV/1; Waste Book 1745-1766, Liverpool, ODAV
} 
—slaving, non-slaving, and financial securities - contributed to Davenport's financial success.

At present, remarkably little is known about how Liverpool merchants organised their companies to finance and manage slaving voyages. When David Richardson considered the way in which Davenport organised slaving voyages in 1976, for example, he noted that "our knowledge of the internal workings of [slaving] partnerships is... very incomplete." Although research into the use of credit in the Atlantic economy-most notably by Jacob Price, B.L. Anderson and, more recently, Peter Mathias - has advanced our knowledge of how slaving merchants used credit to finance their voyages, Richardson's statement still holds true. ${ }^{4}$ Thus, in order to understand how William Davenport profited from the slave trade we will first have to consider how he structured his company to reap those profits.

We can best understand the financial organisation of Davenport's slaving merchant house through the peculiar way in which slaving ventures were organised. The slave trade was unique because its investors owned both a Guineaman's hull and its cargo. ${ }^{5}$ The ship, stores and cargoes were purchased by the ship's husband (often with the guidance and assistance of current or former slaving captains), a role adopted by Davenport for most of his career. ${ }^{6}$ The ship's husband made purchases in two different ways. Firstly, he bought items using "Tradesman's notes"-bills of credit with terms ranging, according to the type of goods purchased, from two months to a year, and comprising between half to two thirds of the total outlay on the voyage. Secondly, the husband purchased items with cash, usually at a discount of 10-20 percent from the credit price. $^{7}$ After drawing up the voyage accounts, he notified each

\footnotetext{
${ }^{3}$ Richardson, "The Accounts of William Davenport," p.67

${ }^{4}$ Anderson, "The Lancashire Bill System," pp.59-97; Anderson, "Financial Institutions on Merseyside," , pp.26-53; Price, Capital and Credit in British Overseas Trade: The View from the Chesapeake, 1700-1776, ; Jacob M. Price, "Credit in the Slave Trade and Plantation Economies," in Slavery and the Rise of the Atlantic System, ed. Barbara L. Solow, (Cambridge: 1994), pp.293-339; Peter Mathias, "Risk, Credit and Kinship in Early Modern Enterprise," in The Early Modern Atlantic Economy, ed. John J. McCusker and Kenneth Morgan, (Cambridge: 2000), pp.15-35.

${ }^{5}$ In other overseas trades, such as the West India or Mediterranean trades, ship-owners charged freight to carry goods in the hulls of their vessels.

${ }^{6}$ Davenport managed seventy-four ventures from 1753-1785 (Based on the Trading Accounts in the Davenport papers, and the ownership data in the Voyages Database).

${ }^{7}$ Richardson, "The Accounts of William Davenport," pp.71-72
} 
partner of their "division" of the ship by giving them a list of the tradesmen's notes to remit, and a portion of the disbursements according to their share in the vessel. ${ }^{8}$

Although the ship's husband had expended large sums of money on the disbursements, he did not expect the partners to immediately reimburse him. Instead he placed the amount owed by each partner into his accounts ledger. These accounts were ongoing affairs, rarely balanced off to settle outstanding debts, as large balances offset against each other as partners transacted business. ${ }^{9}$ Investments in slaving ventures went into the accounts alongside other transactions, and hence remained outstanding for a year or more. In the mean time the slaving vessel would have made its voyage and returned with the remittances from the slave sale.

Bills of exchange were the most common form of remittance in the Liverpool slave trade. The bill of exchange involved three different parties: the drawer, the payee, and the guarantor. The drawer instigated the bill of exchange by writing out a pro-forma that instructed the guarantee to pay an amount to the payee after a certain period of time had elapsed. In a slave sale, the drawer was the American factor who had sold the enslaved Africans; the payee the managing partner of the slaving voyage; and the guarantor was typically a London banker. ${ }^{10}$ When carried back to Liverpool, the bills were sent either to London or a local banking house to be accepted by the guarantor. If accepted, the bills then became "good" and could be either kept until their maturity, by which time they were realised for their full value, discounted for cash at a rate of five percent or transferred, also at a discount.

The main advantage to the "bills in the bottom" system was that it removed the need to bring remittances home in the form of produce as barter. ${ }^{11}$ Loading sugar in the Americas and selling the commodity in Liverpool took time, and slaving ships had to compete with West Indiamen to freight the plantation produce home to England. Given that "dispatch is the life of every thing" in a slaving voyage, as

\footnotetext{
${ }^{8}$ Based upon the Trading Accounts in the Davenport papers; On the Dreadnaught's 1776 voyage, for example, the total cost of the voyage was $£ 3,425$, of which $£ 1,761$ was purchased using tradesmen’s notes and £1,664 using cash. As one eighth share holder in the Dreadnaught, John Parker received from Davenport (the ship's husband) seven tradesman's to pay, and a bill for $£ 208$ as his one eighth share of the cash disbursements (Voyages Database 91839; Trading Accounts of the Dreadnaught 1776-1777, Liverpool, ODAV).

9 Three of Davenport's ledgers are extant: Ledger Book 1763-1775, Liverpool, ODAV; Personal Ledger 1763-1772, Liverpool, D/DAV/2; and Ledger Book 1788-1797, Liverpool, ODAV. From the opening and closing balances in the Ledger Book 1763-1775, it is clear that he originally kept other ledgers which are now lost.

${ }^{10}$ Price, "Credit in the Slave Trade and Plantation Economies," pp.311-312

11 "Bills in the bottom" was an eighteenth century term used to describe the system. It is alternatively known as the "immediate remittance" system. (Ibid., p.311)
} 
William Earle reminded his former apprentice Isaac Dove, lingering in the West Indies was undesirable. ${ }^{12}$ Moreover sugar prices could decrease while slaving vessels were at sea, and therefore the slaving merchant had no guarantee that his remittances would maintain their value. As a result, the bills in the bottom system became the preferred method to bring slave sales home when compared to the unwieldy and unpredictable produce trade. ${ }^{13}$

A major disadvantage to the bills remittance system was the length of time the bills took to mature. Factors remitted slave sales in three tranches of bills, each with a progressively higher date later until maturity. In peace time, for example, Davenport received credit terms of three, six and nine months. In war time these terms could reach two years or more. ${ }^{14}$ Because banking houses discounted bills based on the length of time remaining until maturity, it was in the interest of slaving merchants to let their bills reach maturity rather than reduce their value through discount. Guinea merchants were particularly loath to discount their bills because of the high value of remittances from slave sales. For example, a relatively small cargo of two hundred captives could be sold for $£ 6,000$ in the Americas, remitted in three bills valued at $£ 2,000$ each. Taking a five percent discount from these bills would sink the profits of the voyage by $£ 300$, a substantial sum that could make the difference between a voyage profit or loss. Moreover, these bills were of little use in the purchase of trading goods because no single item in a slavers cargo cost more than $£ 1,000 .{ }^{15}$ As a result, as Anderson states, Davenport "retained quite long-dated bills of exchange

\footnotetext{
${ }^{12}$ William Earle to Isaac Dove, Liverpool, 22 April 1761, in William Earle's Letterbook, 23 Jan 176023 Sept 1761, Earle Papers, MMM, Liverpool, England

${ }^{13}$ The shift from the produce trade to the bills in the bottom system is evident in Davenport's career. In Davenport's first letter book (1747-1759) he exhorted his captains to bring back produce, or at the very least a freight of produce because "tis a great Loss to have a ship come home in ballast" (William Davenport \& Co. to Captain John Maddocks, Liverpool, 10 July 1755, in Letter and Bill Book 17471761, ODAV). From 1758 onwards, however, Davenport's captains always brought remittances home in bills of exchange. Exceptions to this rule sometimes occurred during the credit crisis of 1772, the Seven Years' War and the American Wars, when factors were forced to make their remittances in produce, or alternatively Spanish silver dollars (Based upon an analysis of the insets of the ventures documented in the Trading Accounts within the Davenport papers).

${ }^{14}$ Credit was also stretched during credit crises, such as in 1772, when many of Davenport's vessels returned with bills ranging from fifteen to twenty-four months (Ibid).

${ }^{15}$ In Davenport's ventures the most expensive category of trading goods was textiles for the Old Calabar market. Although the overall cost of textiles for a vessel may be $£ 1,500-£ 2,500$, purchases were invariably made from two or three suppliers, and the cost split between several of the voyage investors. On the Dobson's 1769 voyage, for example, Christopher Hassel bought $£ 517$ worth of India textiles from Bostock \& Bainbridge of London for the outfit. He split the cost between five of the voyage investors, each of whom had to pay a tradesman's note of $£ 134$ or less. (Trading Accounts of the Dobson \& Fox 1769-1771, ODAV).
} 
even when trade was poor, and only when his own financial position became pressing did he have them discounted."16

When the bills of exchange reached maturity, the ship's husband received the proceeds of the slave sale into his London bank account. After taking account of the costs of clearing the vessel into Liverpool, he calculated the share owed to each partner in the "inset" account. ${ }^{17}$ Exactly like the outward cost of the slaving vessel, the husband placed the inset to the credit of the partner account, an amount that usually cleared the obligation for the cash disbursements and left a surplus. In this way money rarely changed hands for a partner's obligations towards slaving vessels. This was particularly the case between ship's husbands. Take, for example, Davenport's account with William Earle. In the late 1760s, Davenport held investments in Earle's ships Sisters, Friendship and Little Britain. At the same time, Earle possessed a share in Davenport's ships Dalrymple and Neptune. All told, the two men transacted $£ 4,769$ in business between November 1766 and June 1768. Of these transactions just $£ 882$ was actual money changing hands. ${ }^{18}$

Even the "money" changing hands was not necessarily hard currency because, as Anderson asserts, we must "adopt the widest possible definition of money for the eighteenth century." ${ }^{19}$ Merchants carried out most of their transactions with short dated bills of exchange, not with bags of coins, so that even the "cash" disbursements were rarely paid with specie: only the small, incidental items of expenditure costing no more than $£ 5$ were paid with coinage. ${ }^{20}$ All other obligations were cleared through either the accounts ledgers, or paid with short dated inland bills of exchange. The use of bills was necessitated by the government's reluctance to mint sufficient coinage to meet the demands of Britain's rapidly expanding economy. As a provincial town, at a three-day journey's remove from London, Britain's financial hub, Liverpool suffered acutely from a lack of coinage, to the extent that local tradesmen often issued tokens

\footnotetext{
${ }^{16}$ Anderson, "The Lancashire Bill System," p.78

${ }^{17}$ Based upon an analysis of the insets of the Trading Accounts within the Davenport papers

${ }^{18}$ Personal Accounts Ledger 1763-1772, Liverpool, D/DAV/2, ff.28,52,84,123,185

${ }^{19}$ B.L. Anderson, "Money and the Structure of Credit in the Eighteenth Century", Business History, vol. 12, no. 2, (1970), p.86

${ }^{20}$ The major exception tended to be the advance wages paid to the slave ship sailors who were exceptional in receiving two months of their wages in advance pay, rather than the one customary in other trades. Moreover, slave ships took large crews compared to other trades as extra men were needed to guard and feed the slaves, and offset the inevitable mortality on the African coast. As a result the ship's husband had to pay out between $£ 150$ and $£ 300$ to the sailors before the ship sailed, a large proportion of the actual cash changing hands during a voyage (Behrendt, "Human Capital," p.73).
} 
in place of cash. ${ }^{21}$ In the absence of specie, bills acted as paper currency throughout the eighteenth century, a transferable note backed by the London banks. Nonetheless, the bills were still instruments of credit, not coinage, and hence the entire system of finance rested upon trust and confidence in the banks and the merchant community to honour them.

Thus, the Liverpool slave trade was financed almost entirely by credit transactions in one form or another. Credit between partners paid for the outfitting costs of slave ships; tradesmen's notes paid for the hull and the cargoes; short dated bills paid for "cash" disbursements; and bills of exchange drawn on London banks returned slave sales. Such was the reliance upon bills of credit that a slaving voyage may involve less than $£ 250$ of actual specie changing hands. To illustrate the ubiquity of credit transactions, consider the voyage of Davenport's ship William, a small vessel trading to Cameroon in 1769 . The William cost $£ 2,141$ to fit out of which $£ 429$ were tradesmen's notes and $£ 1,363$ cash disbursements. The actual amount of "cash" expended on the disbursements was, however, just $£ 119$. The rest of the William's disbursements were cleared through the accounts ledger, later to be paid with bills of exchange. The William's inset also involved little cash changing hands. When the vessel returned to Liverpool, Davenport had to issue $£ 108$ in specie to clear the seamen's wages and other miscellaneous expenses. The rest of the William's inset consisted of three $£ 621$ bills of exchange that Davenport sent to his London banker and, upon their acceptance, placed to the credit of his partner's accounts. In total, then, the William's venture involved just $£ 227$ of actual cash changing hands out of nearly $£ 4,000$ in transactions. ${ }^{22}$

To pay for the cash disbursements, the ship's husband still required a large supply of small bills on hand. Davenport sourced bills locally by trading in goods with short terms of credit. We can establish what lines of trade Davenport dealt in thanks to the existence of two waste books - small memorandum books recording sales - covering the concurrent periods 1745-1765 and 1766-1780. ${ }^{23}$ Although David Richardson scanned the first waste book in his study of Davenport's profits, no

\footnotetext{
${ }^{21}$ Anderson, "Financial Institutions on Merseyside," p.28

${ }^{22}$ Trading Accounts of the William 1766-1773, ODAV

${ }^{23}$ Waste Book 1745-1766, Liverpool, ODAV; Waste Book 1766-1780, Liverpool, D/DAV/2
} 
historian has examined either waste book in detail. ${ }^{24}$ For the purpose of this study the waste books have been entered into a database to provide as complete a picture as possible of Davenport's trading concerns. In total the two waste books record 4,167 transactions, the majority of which occurred locally, and typically recorded the sale of goods to other Liverpool merchants. Other transactions record business with a network of British and Irish customers, most of whom were concentrated in London and the counties of Northern England. There is also a small amount of business with European merchants, although these are almost all with William and James Manson, a firm of Scottish émigré merchants fixed in Rotterdam, and Earle and Hodgson, Davenport's bead supplier.

The first waste book shows Davenport acting very much as a general merchant for the first years of his career. Throughout the 1740s and 1750s he imported produce, such as sugar, wine, sweet meats and ginger, and vended them in his capacity as a grocer. He was joined in this endeavour with George Clowes, a Cheshire gentleman who had apprenticed with Whaley, and with whom Davenport sold $£ 600$ worth of produce in their first three years of trade, 1748-1750. Davenport and Clowes also traded for ivory by sending "small private adventures" to Africa to "barter for Teeth of ye best kind." 25 From 1751, Davenport also shipped Irish linen and glue in company with his relative Thomas Egerton. ${ }^{26}$ They sold the majority of the wares in northwest England, but some may have been shipped to the West Indies in exchange for groceries, as Davenport traded "a few pieces of ... wide Irish linens" to Jamaica in exchange for "good Muscovado Sugar, Ginger and Pimineto" in April 1755. ${ }^{27}$ In the same year Davenport abandoned the Irish linen trade because "there seems to be little, or no demand" for linen in Liverpool. ${ }^{28}$

By 1760, Davenport had also left the grocery trade as he specialised his business in Africa. For the remainder of his career, the vast majority of Davenport's dealings concerned the sale of goods to, or the purchase of items from, slaving vessels. As we saw in chapter two, Davenport vended beads, iron bars, iron hoops,

\footnotetext{
${ }^{24}$ David Richardson, "A Brief Introduction to the Microfilm Edition of the William Davenport Papers," British Online Archives, 1998, available from http://www.britishonlinearchives.co.uk/9781851171767.php, p.4

${ }^{25}$ William Davenport to Captain John Simmons, Liverpool, 12 August 1748, in Letter and Bill Book 1747-1761, ODAV

${ }^{26}$ Thomas Egerton is presumably related to Davenport's aunt Christina Egerton.

${ }^{27}$ William Davenport to Messrs Southwark \& Case, Liverpool, 21 April 1755, in Letter and Bill Book 1747-1761, ODAV

${ }^{28}$ Ibid.
} 
and wine to slaving vessels. Aside from selling goods to slavers, Davenport's other major business was brokering ivory. Purchasing ivory in Africa was very much an adjunct to slave trading in that "elephant's teeth" were bartered on the African coast and carried in slaving vessels. However, Davenport's ivory business was in many senses operated as a separate concern from his slaving house. Only a quarter of the ivory Davenport purchased between 1763 and 1785 came from his own vessels. ${ }^{29}$ Moreover, from 1748 until 1769 Davenport operated his ivory company as a partnership, first with George Clowes, and then with Elizabeth Roughsedge, a local ironmonger who did not invest in the slave trade. ${ }^{30}$ We can hence consider Davenport's slaving and ivory trading as different branches of his merchant house.

Davenport's ivory business occupied a large amount of his capital and time. From 1748 until 1762, Davenport's ivory company sold $£ 9,500$ of ivory, of which he contributed $£ 5,000-£ 7,000$, a sum equivalent to roughly half to two thirds of the money he invested in slaving vessels in the same period. ${ }^{31}$ From 1763 until his retirement in 1786 , Davenport sold a further $£ 26,555$ worth of ivory, roughly a quarter of his slaving investments in this latter period. ${ }^{32}$ Some idea of the effort Davenport required to vend these large quantities of "teeth" is revealed within the Ivory Book, which contains copies of his outward letters from February 1779 to January $1784 .{ }^{33}$ In the five year period, Davenport sold ninety-three lots of ivory to a group of Liverpool, Sheffield, Dublin and Glasgow cutlers, comb makers, cabinet manufacturers and brokers. Each sale required Davenport to correspond with his purchaser, weigh and package the lot, and arrange shipment to their various destinations, in addition to purchasing the ivory at auctions and private sales.

Davenport purchased ivory from incoming slaving vessels in large lots typically weighing half a ton or more, and costing at least $£ 100$. If purchased from

\footnotetext{
${ }^{29}$ For the purpose of this study, Davenport's ivory transactions have been entered into a spreadsheet. Any analysis of the Ivory Book has been derived from interpretations of that spreadsheet (Ivory Book 1763-1785, Liverpool, D/DAV/1).

${ }^{30}$ Ibid; Waste Book 1745-1766, Liverpool, ODAV; Elizabeth Roughsedge was probably the widow of Edward Roughsedge, who invested in the slaver Cumberland with William Whaley five times in 17481753 (Based on the ownership data in the Voyages Database). In 1766, her business is listed as "Elizabeth Roughsedge \& Son, ironmongers" (Gore, Liverpool Directory 1766, p.26).

${ }^{31}$ Waste Book 1745-1766, Liverpool, ODAV. Davenport's level of investment in the Liverpool slave trade has been taken from the calculations made in chapter one.

${ }^{32}$ Ivory Book 1763-1785, Liverpool, D/DAV/1

${ }^{33}$ There are a total of 447 letters in the Ivory Book for the entire four year period. They have all been transcribed for the purpose of this thesis. In the letters concerning ivory trading, Davenport typically gives news of the market, details any ivory lots sent, and requests remittances for previous orders (Ivory Book 1763-1785, Liverpool, D/DAV/1).
} 
other slaving merchants, Davenport paid for these lots using bills of exchange; if purchased from his own vessels the cost of the ivory was deducted from his share of the venture's proceeds. ${ }^{34}$ Davenport brokered these large lots down into small orders of, on average, $£ 50$, sold on credit terms ranging from six weeks to two months, and remitted in short dated bills. ${ }^{35}$ In March 1780, for example, Davenport wrote Broomhead \& Ward, a Sheffield cutler:

Sirs, I recvd yours this day enclosing three bills value one hundred \& fifty two pounds nineteen shillings which are passed to your credit $^{36}$

As the letter shows, Davenport's customers often remitted the balances due for ivory sales in batches of small bills. These bills were of use to Davenport as he could pass them on to his own suppliers. In the same month as he corresponded with Broomhead \& Ward, for example, Davenport wrote Charles Ford, a Manchester textile manufacturer:

Sir, Inclosed Eight bills as under Value One hundred \& Eighty Eight Pounds eleven shillings which discharges your bill for the Goods bought by Capt Begg for the Brig William ${ }^{37}$

Davenport listed the eight bills that made up the balance at the bottom of the letter, only one of which exceeded $£ 50$. This pattern repeats throughout Davenport's letter book, confirming that he converted large sums of capital into smaller more manageable supplies of money through his dealings in ivory.

The goods Davenport vended to slaving vessels also returned a steady supply of money. Iron bars and iron hoops, Davenport's second largest non-slaving concern, were vended at two months credit; beads returned either cash or bills at four months credit; wine was traded for cash. ${ }^{38}$ Like ivory, Davenport bought these goods in large batches, paid for out of his London account using bills of exchange. He then broke the bulk supplies down into smaller individual orders returning him small bills.

The financial organisation of the slave trade thus explains exactly how Davenport organised his merchant house. Because extensive credit financed slaving vessels, and slave sales were remitted in large unwieldy bills of exchange, Davenport,

\footnotetext{
${ }^{34}$ Ledger Book 1763-1775, Liverpool, ODAV; Personal Ledger 1763-1772, Liverpool, D/DAV/2; and the inset sections of the Trading Accounts in the Davenport papers.

${ }^{35}$ Ivory Book 1763-1785, Liverpool, D/DAV/1; Waste Book 1766-1780, Liverpool, D/DAV/2

${ }^{36}$ Davenport to Broomhead \& Ward, Liverpool, 3 March 1780, D/DAV/1

${ }^{37}$ William Davenport to Charles Ford, Liverpool, 24 March 1780, D/DAV/1

${ }^{38}$ Waste Book 1766-1780, Liverpool, D/DAV/2
} 
as a ship's husband, needed to keep on hand a steady supply of money. He maintained that supply of money by dealing in "non-slaving" commodities-ironware, beads, wine and ivory - that returned smaller, more manageable bills of exchange. Far from being ancillary to Davenport's business, these commodities maintained the liquidity of his trading house: only by dealing in non-slaving commodities could Davenport participate in the slave trade over a thirty-eight year period.

Having established how Davenport financially organised his company, we are now in a position to discuss his slaving profits. Davenport's slaving profits have been examined by David Richardson and Joseph Inikori, both of whom interpreted the ship accounts differently. The major difference between the two historian's methodologies was the discounting for credit transactions. Richardson argued that in order to arrive at "real" profits, we must incorporate a discount for the tradesmen's notes in the outgoing expenses, and discount the bills of exchange in the inset. Inikori, by contrast, argued that we should follow Davenport's methodology and hence make no allowance for credit (see Appendix A for details). Because this thesis is interested in the influence profits had on Davenport's business decisions, we will adopt his own methodology — how Davenport reckoned his profits - and hence take no account of discounts for credit.

Adopting Davenport's methodology has the major advantage that it allows us to extend our sample of slaving voyages from which to calculate profits. Using Richardson's methodology, we are restricted to only those voyages with accounts detailing the split between cash and credit transactions, of which there are seventyfour in the Old Davenport papers and six in the New Davenport papers. Applying Davenport's methodology allows us to extend that sample to include a further thirty voyages documented in two accounts ledger within the Old papers. ${ }^{39}$ Including the six voyages in the New papers, we can consider voyage profits for 110 of William Davenport's slaving ventures, thirty-six more than Richardson's sample, and twentyfour more than Inikori's. The first voyage in the extended sample was the Chesterfield, sailing to Calabar in July 1757; the last is the ship and tender voyage of the Perseverance and Oronoko, Davenport's penultimate venture which concluded in

\footnotetext{
${ }^{39}$ Ledger Book 1763-1775, Liverpool, ODAV; Ledger Book 1788-1797, Liverpool, ODAV
} 
Liverpool on 8 August $1785 .^{40}$ The Essex, Davenport's last venture, is not documented in sufficient detail to calculate profits. ${ }^{41}$ In the twenty-nine year period between the Chesterfield and Essex's voyages, Davenport financed 142 ventures. ${ }^{42}$ The sample of 110 voyages therefore encompasses three quarters of Davenport's investments in the period 1757-1786 (see Appendix B for a listing of each sampled voyage and their profits).

The sample is most detailed for the years 1762-1778 when we can calculate profits for all but seven of Davenport's ninety-six voyages. ${ }^{43}$ From 1779 until 1786, the last years of Davenport's career, we have detail for fifteen of thirty-one ventures. The main gaps in our knowledge of Davenport's profits cover the beginning of his career. Prior to 1757 , there are scattered clues within Davenport's correspondence regarding his profits on certain voyages, but no voyage accounts survive to calculate specific earnings. ${ }^{44}$ Even after 1757, there are only voyage accounts for six of the sixteen voyages he financed until 1762, when the ledger book commences. ${ }^{45}$ The lack of voyage accounts from 1748 to 1762 occurred during years when Davenport invested only twelve percent of his total career capital in the slave trade. In fact, thanks to the sample being concentrated on the peak years of Davenport's investment, 1766-1779, we can calculate returns on seventy percent of the capital he invested in the slave trade, the most complete study of any Liverpool slaving merchant to date.

\footnotetext{
${ }^{40}$ Voyages Database 83063 (Perseverance) and 82973 (Oronoko)

${ }^{41}$ Voyages Database 81312 (Essex) and 80829 (Christopher)

${ }^{42}$ Based on the voyages documented in the Old and New Davenport Papers and the ownership data in the Voyages Database

${ }^{43}$ The missing seven voyages arises largely because of a lack of sources for the Charles, a vessel managed by Alexander Nottingham that made five voyages in the period 1770-1776 (Voyages

Database 91635-91639). For the first four voyages the outward investment is recorded in the debit side of the Ledger Book 1763-1775, but the credit page is torn out. For the Charles' final voyage in 1776 there is no information in the ledger at all and no corresponding ship account. For the same reason, we cannot calculate profits for the Patty or the Fox (Voyages Database 91827, 91806).

${ }^{44}$ In letters to his brother Davies, for example, Davenport asked for "a small supply of money" because he had met "misfortunes at sea." (William Davenport to Davies Davenport, Liverpool, 20 June 1752, BDM). He later complained that after the Chesterfield's third voyage (Voyages Database 90180) "I veryly [sic] believe I shall be $£ 50$ or $£ 60$ clear into pocket for my $1 / 8^{\text {th }}$ part," implying a loss of at least ten percent on his capital (William Davenport to Davies Davenport, Liverpool, 20 July 1752, BDM).

${ }^{45}$ These six accounts are, in fact, separate from the original cache of "Old" Davenport papers and are housed at the Liverpool Record Office, England. However, they clearly belonged to Davenport as the accounts are made out by him.
} 
Table 6: Slaving Voyages Not Included In Richardson's Davenport Venture Profit Calculations

$\begin{array}{rrr}\text { VID } & \text { Name } & \text { Year } \\ 90906 & \text { Union } & 1762 \\ 91016 & \text { Dalrymple } & 1762 \\ 91066 & \text { Delight } & 1763 \\ 91017 & \text { Dalrymple } & 1763 \\ 91038 & \text { Friendship } & 1763 \\ 90907 & \text { Union } & 1764 \\ 91067 & \text { Delight } & 1764 \\ 91218 & \text { Dalrymple } & 1765 \\ 91039 & \text { Friendship } & 1765 \\ 91247 & \text { Union } & 1765 \\ 91256 & \text { Active } & 1765 \\ 91219 & \text { Dalrymple } & 1766 \\ 91158 & \text { Little Britain } & 1766 \\ 91313 & \text { Friendship } & 1766 \\ 91354 & \text { Union } & 1767 \\ 91360 & \text { Dobson } & 1767 \\ 91395 & \text { Good Intent } & 1767 \\ 91355 & \text { Union } & 1768 \\ 90958 & \text { Kildare } & 1770 \\ 91356 & \text { Union } & 1770 \\ 91694 & \text { Patty } & 1771 \\ 91803 & \text { Fox } & 1771 \\ 92017 & \text { King George } & 1773 \\ 91936 & \text { Sam } & 1774 \\ 91805 & \text { Fox } & 1774 \\ 91576 & \text { Hector } & 1776 \\ 91794 & \text { Swift } & 1776 \\ 92589 & \text { Dalrymple } & 1777 \\ 92728 & \text { Swift } & 1777 \\ 92461 & \text { Mars } & 1779 \\ 92474 & \text { Ann } & 1779 \\ 82482 & \text { Mars } & 1780 \\ 83413 & \text { Rover } & 1782 \\ 80251 & \text { Ann } & 1780 \\ 83063 & \text { Perseverance } & 1784 \\ 82973 & \text { Oronoko } & 1784\end{array}$

Source
Ledger Book 1763-1775, Liverpool, ODAV
Ledger Book 1763-1775, Liverpool, ODAV
Ledger Book 1763-1775, Liverpool, ODAV
Ledger Book 1763-1775, Liverpool, ODAV
Ledger Book 1763-1775, Liverpool, ODAV
Ledger Book 1763-1775, Liverpool, ODAV
Ledger Book 1763-1775, Liverpool, ODAV
Ledger Book 1763-1775, Liverpool, ODAV
Ledger Book 1763-1775, Liverpool, ODAV
Ledger Book 1763-1775, Liverpool, ODAV
Ledger Book 1763-1775, Liverpool, ODAV
Ledger Book 1763-1775, Liverpool, ODAV
Ledger Book 1763-1775, Liverpool, ODAV
Ledger Book 1763-1775, Liverpool, ODAV
Ledger Book 1763-1775, Liverpool, ODAV
Ledger Book 1763-1775, Liverpool, ODAV
Ledger Book 1763-1775, Liverpool, ODAV
Ledger Book 1763-1775, Liverpool, ODAV
Ledger Book 1763-1775, Liverpool, ODAV
Ledger Book 1763-1775, Liverpool, ODAV
Ledger Book 1763-1775, Liverpool, ODAV
Ledger Book 1763-1775, Liverpool, ODAV Ship Accounts 1768-1787, Liverpool, D/DAV/2 Ledger Book 1763-1775, Liverpool, ODAV Ledger Book 1763-1775, Liverpool, ODAV Ledger Book 1763-1775, Liverpool, ODAV Ledger Book 1763-1775, Liverpool, ODAV Ship Accounts 1768-1787, Liverpool, D/DAV/2 Ship Accounts 1768-1787, Liverpool, D/DAV/2 Ship Accounts 1768-1787, Liverpool, D/DAV/2 Ledger Book 1788-1797, Liverpool, ODAV Ship Accounts 1768-1787, Liverpool, D/DAV/2 Ship Accounts 1768-1787, Liverpool, D/DAV/2 Ledger Book 1788-1797, Liverpool, ODAV Ledger Book 1788-1797, Liverpool, ODAV Ledger Book 1788-1797, Liverpool, ODAV

Source: In 1976 David Richardson calculated profits for seventy-four of Davenport's slaving ventures (Richardson, "Profits in the Liverpool Slave Trade," pp.82-87). Table 6 lists thirty additional voyages documented in three sources: Ledger Book 1763-1775, Liverpool, ODAV; Ledger Book 1788-1797, Liverpool, ODAV; Ship Accounts 1768-1787, Liverpool, D/DAV/2.

Davenport's total outlay on the 110 sampled slaving ships from 1757 to 1785 was $£ 79,237$, and to this figure must be added $£ 17,140$ on insurances, and the outward cost of the vessel, giving a total investment of £94,399. On the inward side, Davenport received $£ 106,895$ in receipts. His total profit from 110 slaving ventures was thus $£ 10,518$, or a 10.9 percent return on his initial investment. We can gauge 
Davenport's satisfaction with this level of profit from several eighteenth century sources. An oft quoted opinion is that offered by John Tarleton, a large slaving merchant who traded between 1783 and 1807. During his interrogation by Parliamentary Counsel in 1788, Tarleton was asked "What is the Rate of Profit percent. On [the Slave Trade] Annually, at Liverpool?" He replied, "We have always stated that Ten percent. Ought to be the Net Profit in the African trade." ${ }^{46}$ During the same hearings Robert Norris, a former slave ship captain and merchant, stated that he would not "risk" his capital to Africa "under $£ 10$ [percent]." appear to be in line with contemporary expectations of business profits. Adam Smith wrote in 1775 that

Double interest [10 percent] is in Great Britain reckoned what the merchants call a good, moderate, reasonable profit; terms which I apprehend mean no more than a common and usual profit ${ }^{48}$

It would appear, then, that Davenport would have been pleased with his 10.9 percent overall rate of return from slave trading.

Davenport's average return masks, however, large variations between individual venture profits. Earnings fluctuated considerably from substantial profits of seventy percent or more, to outright losses up to sixty percent. The best way to understand these fluctuations is to divide the sample into five distinctive periods, and within those periods examine the African regions to which the vessels traded (Table 7). Table 7: Venture Profits On 110 of Davenport's Slaving Ventures by Period of
Investment, 1757-1785

\begin{tabular}{|c|c|c|c|c|c|}
\hline & Ventures & Out (£) & $\operatorname{In}(\mathfrak{f})$ & $\begin{array}{l}\text { Profits } \\
\text { (f) }\end{array}$ & $\begin{array}{c}\text { Profit } \\
(\%)\end{array}$ \\
\hline $1757-1767$ & 31 & 16,986 & 18,392 & 1,407 & $8.3 \%$ \\
\hline $1768-1771$ & 30 & 20,261 & 24,165 & 3,904 & $19.3 \%$ \\
\hline $1772-1774$ & 22 & 21,202 & 22,906 & 1,704 & $8.0 \%$ \\
\hline $1775-1777$ & 12 & 18,346 & 18,487 & 141 & $0.8 \%$ \\
\hline \multirow[t]{2}{*}{$1778-1785$} & 15 & 19,583 & 22,946 & 3,363 & $17.2 \%$ \\
\hline & 110 & 96,377 & 106,895 & 10,519 & $10.9 \%$ \\
\hline
\end{tabular}

Source: Ledger Book 1763-1775, Liverpool, ODAV; Ledger Book 1788-1797, Liverpool, ODAV; Trading Accounts, Liverpool, ODAV; Ship Accounts 1768-1787, Liverpool, D/DAV/2; Voyages Database.

\footnotetext{
${ }^{46}$ Testimony of John Tarleton, $P P$ 68, p.50

${ }^{47}$ Testimony of Robert Norris, PP 68, p. 8

${ }^{48}$ Smith, The Wealth of Nations, p. 200
} 
In the first period of analysis, 1757-1767, Davenport made poor returns primarily because he speculated in African regions outside the eastern Bight of Biafra. Davenport expended $£ 5,875$ on eleven of these slaving ventures, and received just $£ 45$ in profits. His twelve Calabar ventures in the same period also performed badly, due in large measure to heavy losses sustained on the voyages of the Tyrell in 1761 and the Dobson in $1767 .{ }^{49}$ The Tyrell suffered from the rising outfitting costs caused by the Seven Years War as the captain had been advised that "Industry, and frugality must go hand in hand, or twill be impossible to get a penny [in] these times." 50 The Dobson's voyage, by contrast, lost money probably because of a violent dispute between the Efik traders in the rival Old Calabar villages Old Town and New Town. Merchants in these two Efik villages had long been in competition for European business and, by 1767, the quarrel between the two began to impinge on the supply of slaves. In August 1767 a captain of a slaver lying alongside the Dobson at Calabar, wrote to his owners that he "never saw a worse prospect in my life of making a voyage than at present." ${ }^{51}$ As a result of the feud, Dobson lost her owners fifty-three percent of their capital. Davenport's pioneering forays into the Cameroon market offset some of these losses as all of the sampled voyages returned a profit, with the Union making particularly good returns of $£ 732$ on a $£ 2,317$ investment over three voyages.

The period of slave trading, 1768-1771, proved to be one of the most financially rewarding in Davenport's career. The run of success continued at Cameroon as six of the eight vessels trading there cleared a profit, including the William in 1768 and the King of Prussia in 1771, both of which made fifty percent returns. ${ }^{52}$ Only the Henry and King of Prussia's 1769 voyages to scout the markets around Cameroon lost their owners money, and that was less than one percent. ${ }^{53}$ The great success of Davenport's Cameroon ventures was exceeded only by his Calabar ventures: all but one of his voyages made profits in excess of twenty percent, perhaps aided by the resolution of the conflict between the Efik. The only blot on Davenport's run of success was his $£ 1,253$ investment in the Benin ship True Blue. On the middle

\footnotetext{
${ }^{49}$ Voyages Database 90858 (Tyrell), 91360 (Dobson), 91395 (her tender, Good Intent)

${ }^{50}$ John Maine \& Co. to Captain William Hindle, Liverpool, 7 February 1761, in Trading Accounts of the Tyrell 1761-1762,ODAV

${ }^{51}$ Williams, Liverpool Privateers, p.535

${ }^{52}$ Voyages Database 91215 (William) and 91410 (King of Prussia)

${ }^{53}$ Voyages Database 91082 (Henry) and 91408 (King of Prussia)
} 
passage, the True Blue had lost 156 of her enslaved Africans, from an original cargo of 365 , an event that produced a loss of twenty-one percent to her owners. ${ }^{54}$

The profits Davenport earned in the late 1760s stemmed in part from changes in the British Atlantic economy. At the Peace of Paris in February 1763 Britain had received nearly all of France's American possessions including a small group of islands in the Caribbean: the Grenadines, Tobago, St. Vincent, and Dominica. The Ceded Islands, as they were collectively known, belied their small size-measuring just 674 square miles - with their potential, having been largely untapped by their French former owners. ${ }^{55}$ As a result, the Ceded Islands appealed to ambitious Britons who sought fortunes by converting the islands to sugar and coffee production. Elsewhere in the Caribbean, the planters on Jamaica, Antigua, and Barbados also wanted to convert their islands to specialist sugar production, hoping to meet a rapidly increasing domestic demand during the "silver age" of sugar 1763-1775. ${ }^{56}$

Beginning in 1767, Davenport exploited the expansion of the British Atlantic economy by sending his Guineamen to Dominica, Grenada, and Barbados. Dominica, in particular, provided a ready market for Old Calabar slaves, explaining in part the healthy returns Davenport received from his ventures in the period 1768-1771. ${ }^{57}$ By contrast, Davenport used Grenada and Barbados as an outlet for his Cameroon slaves, a decision perhaps based on the planters' desires for the correct "type" of slave. ${ }^{58}$ Using this Cameroon to Grenada/Barbados, Calabar to Dominica marketing strategy, Davenport shifted his focus away from the more settled and established islands to the frontier colonies.

\footnotetext{
${ }^{54}$ Voyages Database 91643

${ }^{55}$ R.B. Sheridan, Sugar and Slavery: An Economic History of the West Indies, 1623-1775, 2nd ed., (Kingston: 1974), p.454

${ }^{56}$ Richard Pares coined the term "silver age" to refer to the boom years prior to the American War. He defined the "golden age" of sugar as the 1640s (Richard Pares, "A London West India Merchant House 1740-1769," in Essays Presented to Sir Lewis Namier, ed. Richard Pares, AJP Taylor, and Lewis Namier, (London: 1956), p.99)

${ }^{57}$ Davenport landed his first cargo of slaves at Dominica in 1769 when the Fox arrived there from Old Calabar (Voyages Database 91553). The enslaved cargo “averaged” $£ 30$ per person, a substantial improvement on the $£ 25-27$ per person Davenport received from Barbados and Grenada at the same time (Trading Accounts of the Dobson and Fox 1769-1771, ODAV). After this initial success, Davenport dispatched a further three vessels to Dominica in the period 1769-1770, and then six vessels there in 1771 (based upon American markets documented in the Voyages Database).

${ }^{58}$ Davenport did not send a cargo of Cameroon Africans to Dominica until the voyage of Charles in 1769 (Voyages Database 91635). The venture must have achieved a low average slave price there, because Davenport's Cameroon traders did not return to the island until 1774. This would strongly indicate that Dominica planters had a marked preference for Old Calabar, rather than Cameroon slaves, until the mid 1770 s.
} 
Despite establishing an Africa/ America marketing strategy, Davenport had mixed returns from his slaving investments in our third period of study, 1772-1774. The Cameroon market continued to give consistent and high returns of, on average, thirty-five percent venture profits but these successes were balanced by losses averaging twelve percent at Old Calabar. The availability and price of captive Africans was the main reason for the disparity between the regions. Between 1772 and 1774, Davenport's eleven Calabar slavers - totalling 1,900 tons of shipping and costing $£ 50,000$ to fit out-landed 1,609 Africans in the Americas, a cost of $£ 31$ sterling per person. The ten Cameroon vessels trading in the same period-also measuring 1,900 tons and also costing $£ 50,000$ to fit out-landed 2,050 captives, a cost of just £24. Cameroon captains paid less for their slaves in Africa. ${ }^{59}$

In America, Davenport's Cameroon captains also sold their enslaved Africans for $£ 34$ sterling, compared to $£ 31$ averaged by their Calabar counterparts. ${ }^{60}$ The disparity in slave prices arose because Davenport's Cameroon captains were more successful at purchasing higher "quality" captive Africans than their Old Calabar equivalents. ${ }^{61}$ The main decider of "quality" was the age and sex of the enslaved cargo. Planters sought "prime" adult male slaves, and paid a premium for them over women and children. In the period 1772-1774, Davenport's Cameroon cargoes consisted of seventy-three percent male slaves and just twelve percent children. Old Calabar cargoes, by comparison, consisted of just fifty-eight percent men, and thirtythree percent children. Cameroon captains' therefore purchased lower priced, but higher quality captives, explaining the large disparity between Davenport's regional profits in the period 1772-1774.

Davenport's Cameroon captains could purchase better quality, but low priced captives because they faced less competition than Old Calabar traders. In 1765, when Davenport first pushed his investments firmly into the eastern Bight of Biafra, ten slavers traded at Calabar, of which he held shares in just one- the Dalrymple; in 1774 there were eleven European slavers visiting the river, of which Davenport co-owned four. At Cameroon, by contrast, just two slavers traded at the river in 1765, both of

\footnotetext{
${ }^{59}$ Based upon the outfitting records, and slave sales documented in the Trading Accounts for Davenport's Old Calabar and Cameroon ventures, in combination with the tonnage and slave data in the Voyages Database

60 Ibid.

${ }^{61}$ The following is based upon the age/ sex ratios of enslaved cargoes taken from the Voyages Database
} 
them owned by Davenport; in 1774 eight vessels purchased slaves from the Duala, six of them owned by Davenport. ${ }^{62}$ Davenport's Old Calabar captains consequently had to compete with a large number of vessels, resulting in increasing prices and a falling "quality" of enslaved Africans. At Cameroon, Davenport and his small coterie of partners enjoyed a near monopoly over the small number of vessels visiting the river, allowing him to keep slave prices low. As a result, Cameroon returned profits in the first three time periods under consideration, and was only outperformed by Old Calabar in 1768-1771. In fact, between 1757 and 1774, seventy-six percent of his slaving profits came from the region (Table 8).

Table 8: Profits on Davenport's Slaving Ventures by Region, 1757-1774

$\begin{array}{llllll}\text { Region } & \begin{array}{l}\text { No of } \\ \text { Ventures }\end{array} & \text { Out } & \text { In } & \begin{array}{l}\text { Profit } \\ (\mathfrak{E})\end{array} & \begin{array}{l}\text { Profit } \\ (\mathbf{\%})\end{array} \\ \text { Cameroon } & 26 & 19,337 & 24,766 & 5,429 & 28.1 \% \\ \text { Calabar } & 40 & 28,262 & 29,900 & 1,638 & 5.8 \% \\ \text { Other } & 17 & 10,850 & 10,796 & 36 & 0.3 \% \\ & \mathbf{8 3} & \mathbf{5 8 , 4 4 9} & \mathbf{6 5 , 4 6 3} & \mathbf{7 , 1 0 4} & \mathbf{1 2 . 2 \%}\end{array}$

Source: Ledger Book 1763-1775, Liverpool, ODAV; Ledger Book 1788-1797, Liverpool, ODAV; Trading Accounts, Liverpool, ODAV; Ship Accounts 1768-1787, Liverpool, D/DAV/2; Voyages Database

Despite the outbreak of the American rebellion in April 1775, Davenport hoped to build on his previous successes by fitting out further slaving vessels in the period 1775-1777. This proved to be the worst possible decision. By the time Davenport's slavers arrived in the West Indies, American privateers roved the sea, capturing hundreds of the freighting vessels that formed the life blood of planter credit in London. Moreover, the French were soon to enter the war. ${ }^{63}$ As a result of the crisis in confidence produced by the war, Davenport received his slaving receipts in either bills of exchange with terms of credit stretching to two or more years; or planter's bonds-promissory notes that established a balance with Davenport to be paid off by shipments of produce. ${ }^{64}$

Without reliable and prompt remittances, seven of Davenport's eleven Guineamen trading between 1775 and 1778 made losses. Even the formerly fruitful Cameroon produced deficits, with the vessels Sam, Favourite, and Badger costing

\footnotetext{
${ }^{62}$ Based upon the ownership data in the Voyages Database

${ }^{63}$ The French signed an alliance with the Americans on 4 February 1778.

${ }^{64}$ Based on an analysis of the inset sections of the Trading Accounts in the Davenport papers
} 
their owners more than twenty-five percent of their capital, in each case because the planters could not honour their obligations from the slave sales. ${ }^{65}$ Worst of all, recovering the receipts from these voyages took between five and fifteen years, placing a considerable financial burden on Davenport and his partners. ${ }^{66}$ Davenport's finances were slightly redeemed by the Dalrymple's two voyages to Old Calabar in 1776 and 1777, both of which managed to turn a profit by bartering ivory on the African Coast. ${ }^{67}$ However, even these voyages returned, like Davenport's other ventures, with their slave sales in long dated bills of exchange, doing little to alleviate his acute lack of West Indian receipts. ${ }^{68}$

Davenport looked to the slave trade to redeem his finances. He knew well that the lack of Guineamen visiting Africa had created a glut of captives on the Coast, so that, in March 1779 he wrote "Negroes may now be bought 50 percent less than they were 12 months ago." ${ }^{69}$ Moreover he could expect a ready market for the slaves in the West Indies because, as he wrote in the same month, "from the very few vessells gone this last year, \& none fitting out, Negroes must be in great demand \& sell well.,70

These favourable market conditions enabled his captains to secure sizeable returns for Davenport and his partners: five of the ten vessels sampled between 1779 and 1783 made extraordinary profits (Table 9). Only the Ann in 1780, the Hawke in 1781, and the Rover in 1782, lost their owners money, in each case because of ill luck: the Hawke and Rover were both captured by the enemy and Davenport could not claim the full value of the ship on insurance; and the Ann was "detained for some months" at Sierra Leone by an African war in the interior, preventing her from

\footnotetext{
${ }^{65}$ Voyages Database 91937 (Sam), 91978 (Favourite), 92536 (Badger)

${ }^{66}$ As a result of the evaporation of slaving receipts Davenport's long time associates Patrick Black, Robert Jennings, Thomas Hughes, Alexander Nottingham and Christopher Davenport all quit the trade (based on the ownership data in the Voyages Database).

${ }^{67}$ On the Dalrymple's first voyage, Captain Fairweather and his tender William Seaton purchased $£ 1,771$ worth of ivory, compared to slave sales of $£ 10,349$ redeemed in bills at fifteen, eighteen and twenty-four months (Voyages Database 91988 and 91793; Trading Accounts of the Dalrymple 17721777, ODAV; "Inset Account of the Dalrymple and Swift" in Ship Accounts 1768-1787, Liverpool, D/DAV/2). On her second voyage in 1777, Fairweather and his tender Captain Brighouse loaded $£ 3,237$ worth of ivory, compared to slave sales of $£ 11,221$. The slave sales were paid for with bills at twelve, eighteen and twenty-four months (Voyages Database 92589 and 92728; Ibid.).

${ }^{68}$ In 1779, for example, Davenport wrote to one of his London creditors that he was "really ashamed to draw [bills] at such a long date, but the West India bills I have in Denisons [his London banker] hands are at such long credit I could not possibly avoid it, and the Bankers wont discount a bill now that has above six months to run" (William Davenport to John Sowerby, Liverpool, 30 March 1779, D/DAV/1). ${ }^{69}$ William Davenport to Charles Ford, Liverpool, 23 March 1779, D/DAV/1

${ }^{70}$ William Davenport to William \& John Thompson, Liverpool, 1 March 1779, D/DAV/1
} 
loading a sufficient number of captives. ${ }^{71}$ These voyages apart, Davenport earned the most impressive returns of his career from the Hawke who on her first voyage returned eighty-five percent profits, and on her second voyage 173 percent $^{\text {profits. }}{ }^{72}$ The Mars, sailing to the Windward Coast at the same times as the Hawke, also made her owners substantial returns of seventy-one percent and thirty-five percent. ${ }^{73}$ If these windfalls occurred also on the remaining eleven wartime ventures Davenport financed during the period 1779-1783, then they confirm Thomas Clarkson's contention that "During the American war... the adventurer, who escaped the ship of the enemy, made his fortune." 74

Table 9: William Davenport's Slaving Vessels, 1779-1783

$\begin{array}{lllllllll}\text { VID } & \text { Name } & \begin{array}{l}\text { Yr of } \\ \text { Deprt }\end{array} & \text { Market } & \begin{array}{c}\text { Yr of } \\ \text { Arv WI }\end{array} & \mathfrak{£} \text { Out } & \text { In } & \begin{array}{l}\text { Profit } \\ (\mathfrak{f})\end{array} & \begin{array}{c}\text { Profit } \\ (\boldsymbol{\%})\end{array} \\ 92461 & \text { Mars } & 1779 & \text { Sierra Leone } & 1780 & 621 & 1,063 & 442 & 71.2 \% \\ 92462 & \text { Hawke } & 1779 & \text { Cameroons } & 1780 & 741 & 1,371 & 630 & 85.0 \% \\ 92474 & \text { Ann } & 1779 & \text { Windward Coast } & 1780 & 1,219 & 1,437 & 218 & 17.9 \% \\ 83174 & \text { Preston } & 1780 & \text { Cameroons } & 1781 & 963 & 1,087 & 124 & 12.9 \% \\ 82482 & \text { Mars } & 1780 & \text { Sierra Leone } & 1782 & 1,209 & 1,638 & 429 & 35.5 \% \\ 81753 & \text { Hawke } & 1780 & \text { Cameroons } & 1781 & 1,234 & 3,368 & 2,134 & 172.9 \% \\ 80251 & \text { Ann } & 1780 & \text { Windward Coast } & 1782 & 2,811 & 2,665 & -146 & -5.2 \% \\ 81754 & \text { Hawke } & 1781 & \text { Cameroons } & \text { Captured } & 1,731 & 1,096 & -635 & -36.7 \% \\ 83175 & \text { Preston } & 1781 & \text { Cameroons } & 1782 & 1,121 & 1,529 & 408 & 36.4 \% \\ 83413 & \text { Rover } & 1782 & \text { Cameroons } & \text { Captured } & 746 & 654 & -91 & -12.2 \% \\ & & & & & \mathbf{1 2 , 3 9 6} & \mathbf{1 5 , 9 0 8} & \mathbf{3 , 5 1 2} & \mathbf{2 8 . 3 \%}\end{array}$

Source: Ledger Book 1788-1797, Liverpool, ODAV; Trading Accounts of the Hawke 17791783, ODAV; Trading Accounts of the Preston 1780-1784, ODAV; "Trading Accounts of the Mars 1779-1781", in Ship Accounts 1768-1787, Liverpool, D/DAV/2; "Trading Accounts of the Rover 1782-1786", in Ship Accounts 1768-1787, Liverpool, D/DAV/2; Voyages Database.

Note: $W I=$ West Indies

The three extant voyage accounts for Davenport's ventures after 1783 indicate that the favourable market conditions generated by the war did not continue after the Treaty of Paris was signed in September 1783. The Preston and Perseverance, two of the documented post-war ventures, both made losses of fourteen percent, and the

\footnotetext{
${ }^{71}$ Testimony of Peter Whitfield Brancker before the House of Lords, 2HL1/90, PRO, Kew Gardens, London, England, pp.26-27; Voyages Database 80251

${ }^{72}$ Voyages Database 92462,81753

${ }^{73}$ Voyages Database 92461, 82482

${ }^{74}$ Clarkson, An Essay on the Impolicy of the African Slave Trade : In Two Parts, p.29
} 
Quixote made a slim profit of just seven percent. ${ }^{75}$ The upsurge in the slave trade after 1783 probably explains the lack of success in these voyages. Slave prices seem to have quickly recovered on the African coast as vessels rushed to fill the increasing post-war demand for captives in the West Indies. Faced with this competitive market, Davenport took his capital out of slaving and retired (see chapter one where we consider Davenport's reasons for retirement).

The voyages of the Badger and the Hawke highlight the fortunes that could be made and lost through speculation on the slave trade. ${ }^{76}$ Both vessels traded during the war and both purchased their slaves at Cameroon. However, Badger made a loss of twenty-six percent, and Hawke a profit of eight-five percent. Examining what caused the vast disparity in profits between these voyages will identify the factors that dictated the fortunes of Davenport's slaving voyages.

Acting as ship's husband and taking a third share in the venture, in early 1776 William Davenport fitted out the Badger with his brother Christopher, former Cameroon captain Thomas Hughes, ship builder John Galley, and long time associate Robert Jennings. Measuring 272 tons and costing £10,647, the Badger was both the largest and most expensive vessel sent to the Cameroon by Davenport. ${ }^{77}$ Moreover, Davenport's own $£ 3,956$ stake in the voyage was the single largest slaving investment of his career (see Appendix B). During her six months at Cameroon, Badger's captain Peter Potter managed to purchase 415 enslaved Africans and three tons of ivory, of which he "had the misfortune to bury 16 slaves \& loose [sic] two overboard in the River." 78

Potter arrived at Dominica in the West Indies in May 1777, and placed his large and healthy cargo of 399 Africans in the hands of Vance Caldwell \& Vance (VCV), a group of prominent slave factors with connections throughout the

\footnotetext{
${ }^{75}$ Voyages Database 83176 (Preston), 80829 (Perseverance) and 82973 (her tender Oronoko), 83267 (Quixote)

${ }^{76}$ Voyages Database 92536 (Badger) and 81753 (Hawke)

${ }^{77}$ Based upon the ship and ownership information within the Voyages Database and Trading Accounts of the Badger and Fox 1772-1778, Liverpool, ODAV

${ }^{78}$ One of the Africans committed suicide while the Badger lay at Douala. Potter described his death: "[He] was one of ye Doctors Guests which had just recovered a fit of sickness \& as we let them [the slaves] up in the Morning he ran immediately to ye gangway \& jumped straight over board \& tho' we were instantly in both boats after him yet before either could reach him he went down \& we saw him no more" (Peter Potter to William Davenport, Cameroons, 15 October 1776, D/DAV/10).
} 
Americas. ${ }^{79}$ Despite their best endeavours VCV wrote to Davenport that they "never had so much trouble in a Sale," due to the ready availability of prize slaves in the Islands-slaves captured from Guineamen, or kidnapped from plantations by privateers and sold cheaply in the French Caribbean Islands. ${ }^{80}$ As a result, VCV managed "so low an Average" of $£ 26$ sterling per slave, a significant drop from the $£ 33$ Potter averaged during the Badger's previous voyage to Dominica in $1775 .{ }^{81}$ More alarmingly, VCV made their remittances in promissory notes, rather than bills of exchange drawn on London banks, "payable at two years thirty months \& three years after ye Ships arrival at home." 82 The promissory notes, unlike bills of exchange, had no value in of themselves and so, as Davenport wrote in February 1779, "no use can be made of them." 83 Worse of all the notes tied up a large portion of Davenport and his partner's capital so that "it will be morally impossible to raise money to fit out ships." ${ }^{84}$ Even with these setbacks, the Badger ostensibly made a profit of thirty-three percent when she arrived in Liverpool albeit with a long wait before the partners would see any returns. ${ }^{85}$

The prospects of reaping the Badger's profit took a blow when the French captured Dominica in September 1778. Now Davenport would have to draw his Dominican remittances as sugar and coffee sent in neutral ships via Holland. ${ }^{86}$ In 1780 Davenport received another setback with the death of James Caldwell, an event that broke up the partnership of $\mathrm{VCV}^{87}$ Now Davenport had to deal with the

\footnotetext{
${ }^{79}$ For example, Davenport wrote in 1781 that the firm was speculating in tobacco and "sending Goods to Philadelphia" (William Davenport to Mr James Morson, Liverpool, 30 December 1781, D/DAV/1).

${ }^{80}$ Vance, Caldwell \& Vance to William Davenport, Dominica, 23 July 1777, D/DAV/10

${ }^{81}$ Peter Potter to William Davenport, Dominica, 5 November 1775, D/DAV/7

${ }^{82}$ Peter Potter to William Davenport, at Sea, 10 August 1777, D/DAV/10

${ }^{83}$ William Davenport to Vance, Caldwell \& Vance, Liverpool, 28 February 1779, D/DAV/1

${ }^{84}$ Ibid

${ }^{85}$ Most of the profits on the voyages came from the sale of the Badger's hull, three tons of ivory, and a government subsidy on iron and cowry exports (Trading Accounts of the Badger and Fox 1772-1778, ODAV).

${ }^{86}$ In 1777 VCV sent the Prince George to Londonderry where she was to sell her cargo of sugar and hogsheads staves, with the proceeds going to Davenport as a first payment against their debts. John Caldwell sailed with the vessel, presumably as an emissary from VCV to soothe the Liverpool merchants over their outstanding debts (Letters, Bills etc. Voyage of Barque Prince George from Dominica 1777-1778, Liverpool, D/DAV/12). Davenport's attempts to recover his debts via the Netherlands are detailed in a lengthy series of correspondence with VCV in the New Davenport papers (see letters on 27/3/1780, 26/6/1780, 16/9/1780, 29/9/1780, 1/7/1781, 2/9/1781, 30/3/1782 in the Ivory Book, D/DAV/1; and letters on 5/1/1781, 20/4/1781, 4/5/1781, 5/7/1781 in James Morson, Vance Caldwell \& Vance 1775-1781, Liverpool, D/DAV/8).

${ }^{87}$ Robert Vance informed Davenport that "my Partner Mr Caldwell was attacked by a Hot \& Violent Fever \& the Worthy man went off after a short illness. This accident falls very heavy on me in the present distressing times but Ill support myself as well as I can" (Robert Vance to William Davenport, Dominica, 17 January 1780, D/DAV/11).
} 
administrators of Caldwell's estate, and the Vance brothers to recover his debts. As a result of this series of calamities, the proceeds of the Badger's slaves trickled in over the next ten years. Between 1780 and 1788, Davenport received just $£ 2,000$ of the $£ 9,800$ promised for the Badger's slaves; in 1791, the investors received a final dividend on the outstanding debt from the then bankrupted Robert Vance's estate of $£ 820$ on $£ 6,000$. ${ }^{88}$ Assuming that no further receipts would come from the voyage, Davenport finally wrote up the account for the Badger's voyage in May 1792, fifteen years after the ship sailed. The ledger revealed that Davenport's personal loss from the voyage was $£ 1,039$, on an initial investment of $£ 3,956$, the largest venture loss of his career. ${ }^{89}$

In March 1779, when the wrangling with VCV over the Badger's remittances still continued, Davenport fitted out the 218 ton ship Hawke for her first voyage. Davenport placed John Smale, a captain with "many years experience" in the Cameroon trade, in command and, on 1 June 1779 Davenport advised him that:

as this river [Cameroon] has had very little trade for sometime past, we are of opinion you might break with them on very low terms both for slaves \& ivory... and as you'll have no competitors you'll have an opportunity of purchasing the very best of both ${ }^{90}$

Smale clearly had the pick of Cameroon captives: he loaded four hundred slaves into his ship's hold, one hundred more than Davenport had expected. ${ }^{91}$ Moreover, Smale managed to barter six tons of ivory from the Duala, tightly packing his small vessel for the passage to Jamaica. ${ }^{92}$ In spring 1780 the Hawke sailed into Old Harbour, Jamaica with 348 enslaved Africans chained in her hold. The Hawke's voyage was a financial success, reaping Davenport $£ 1,371$ on an outlay of $£ 741$, almost a doubling of the initial capital. The only blot on the voyage was the "monstrous long dates" of

\footnotetext{
${ }^{88}$ Ledger Book 1788-1787, Liverpool, ODAV, f.20

${ }^{89}$ Ibid.

${ }^{90}$ William Davenport to Captain John Smale, Liverpool, 1 June 1779, D/DAV/1

${ }^{91}$ Davenport wrote to his West Indian factors that "We have a vessel call'd the Hawke Capt Smale gone to the Bite the 3rd June last for 300 grown Negroes" (William Davenport to Messrs James \& Evan Baillie, Liverpool, 1 November 1779). In the same letter Davenport states that "you may have a demand for Negroes at St Eustatia for the Spaniards," indicating that he was happy to trade with Spaniards, even though they had entered the war against Britain on 16 June 1779.

${ }_{92}$ Davenport advised Smale on the Hawke's second voyage that "you will have room for 400 slaves or perhaps only 370 but we woud have a preference paid to Ivory and the Number of Slaves reduced to 350 provided the price of Ivory is reasonable" (William Davenport to Captain John Smale, Liverpool, 25 October 1780, D/DAV/1). Given that Smale packed four hundred slaves into his vessel alongside six tons of ivory, the Hawke must have been fully laden when she left Africa.
} 
the bills of exchange drawn for the slave sales at "two[,] two and a half \& three years." $" 93$

Transatlantic slave prices were the primary reason for the disparity in profits between the Badger and the Hawke's voyages. In 1776 Peter Potter's ship had cost $£ 10,647$ and he had managed to purchase 415 slaves so that each enslaved person had cost, on average, $£ 25.7$ sterling in Africa. ${ }^{94}$ Given that VCV sold the enslaved cargo for $£ 26$ sterling Badger's owners hence received a net profit of less than $£ 1$ per slave. Even though the Hawke sailed with a "high premium of insurance, high wages, \& most extravagant outfits," the net cost of the captives in Africa was just $£ 15.3 .{ }^{95}$ Moreover, Smale achieved a much higher average in the West Indies, £33.8, giving his owners a $£ 18.1$ gross profit on each enslaved African sold. The differences in slave prices between Africa and the Americas-less than $£ 1$ per slave on the Badger's voyage and over $£ 18$ on the Hawke's voyage - when multiplied by a cargo of four hundred enslaved Africans, dictated in large part the profits derived in each of the voyages (Table 10).

Table 10: Badger and Hawke to Cameroon, 1776 and 1779

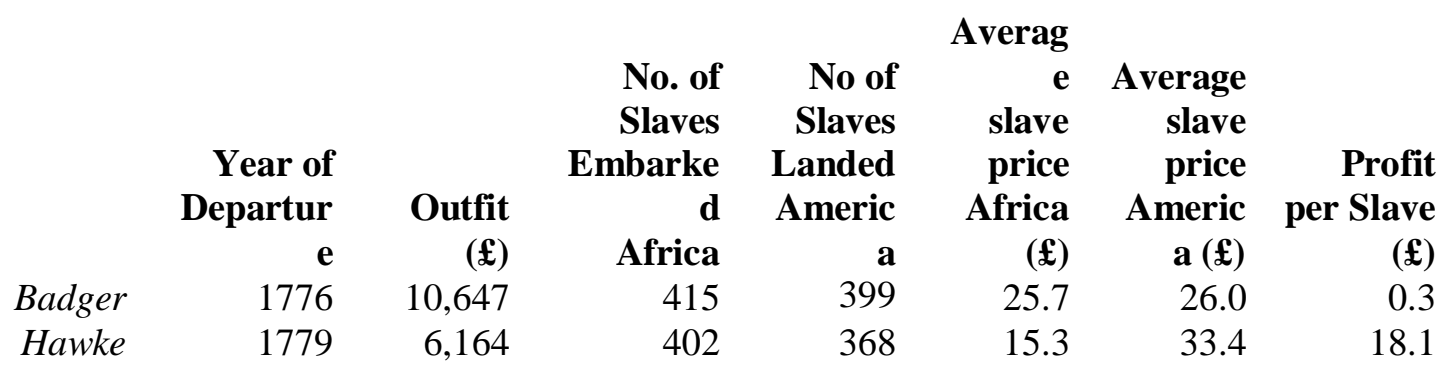

Source: Trading Accounts of the Badger and Fox 1772-1778, Liverpool, ODAV; Trading Accounts of the Hawke 1779-1784, Liverpool, ODAV; Voyages Database

A second factor driving the profitability of Davenport's ventures was his ability to recoup slave remittances in Liverpool. Had Potter returned to Liverpool with the Badger's remittances in safe bills of exchange Davenport could have banked the meagre profits from the slave sales and recovered his capital from the voyage. Instead Davenport received promissory notes that gave no guarantee of payment and ultimately paid out just a third of their face value over fifteen years. The lack of

\footnotetext{
${ }^{93}$ William Davenport to William Thompson \& Company, Liverpool, 1 August 1780, D/DAV/1

94 Trading Accounts of the Badger and Fox 1772-1778, Liverpool, ODAV

${ }^{95}$ William Davenport to Captain John Smale, Liverpool, 1 June 1779, D/DAV/1; Trading Accounts of the Hawke 1779-1784, Liverpool, ODAV
} 
secure remittances thus sunk the venture profits from a healthy thirty-three percent, to a loss of twenty-six percent. Learning from his mistakes in the Badger's voyage, Davenport ensured that the Hawke would receive her remittances in bills of exchange by writing to the factors before hand to establish "the terms of payment" as that was "the only objection we have in fitting out ships to Africa". 96 Although Davenport received the Hawke's slave sale in lengthy bills of exchange, they were guaranteed by a London bank and hence the remittances were safe. Had the Hawke's remittances been made, like the Badger's, in unreliable promissory notes returning just a third of their value, its profits would have sunk substantially. The case of the Badger and Hawke's voyages, thus highlights the crucial importance of slave prices and safe remittances to Davenport's slaving venture profits.

David Richardson has identified the need to purchase, and then keep alive a healthy cargo of captive Africans as a third factor dictating Davenport's venture profits. Using Davenport's ship accounts, Richardson demonstrated that vessels "that failed to deliver more than fifty-five percent of their originally intended complement of slaves to the New World almost invariably made losses."97 Whilst Potter and Smale both managed to purchase their full complement of slaves, and then kept mortality below ten percent, some of Davenport's other captains were not so lucky. The 182 ton William, for example, made a forty-two percent loss because she only carried seventy-seven Africans of her intended 120 captives to the Americas. ${ }^{98}$ Similarly the Lord Cassils and King George, two vessels intending to purchase 650 slaves in total, made a fifty percent loss because they only managed to land 202 slaves in the West Indies. ${ }^{99}$

Attempting to achieve the three criteria necessary for a successful voyage delivering a full complement of low priced captives, selling them in the Americas for high prices, and securing safe remittances — dictated Davenport's business strategy. In the search for large cargoes of low priced captives, Davenport exploited the untapped Cameroon market and invested heavily in the Old Calabar region, shifting his trade away from the competitive and glutted markets in Upper Guinea. In the Americas,

\footnotetext{
${ }^{96}$ William Davenport to William \& John Thompson, Liverpool, 1 March 1779, D/DAV/1

${ }^{97}$ David Richardson, "The Costs of Survival: The Transport of Slaves in the Middle Passage and the Profitability of the 18th- Century British Slave Trade", Explorations in Economic History, vol. 24, (1987), p.180

${ }^{98}$ Voyages Database 91213

${ }^{99}$ Voyages Database 92543 (Lord Cassils), 91865 (her tender May), 92017 (King George)
} 
Davenport sought high slave prices by pushing into the small, un-established, but potentially lucrative Ceded Islands. For much of Davenport's career this business strategy paid rich dividends. His speculation in Cameroon proved to be particularly profitable, providing nearly two thirds of all his sampled slaving profits. However, in marketing slaves in the Ceded Islands - the frontiers of the British Atlantic economy-Davenport increased his risks in securing safe bills of exchange. Once the system of remittance collapsed during the American War, the Ceded Islands boom became a bust, turning Davenport's slaving profits into a loss.

We can cast further light on Davenport's slaving profits by examining his returns from non-slaving lines of trades. The Davenport papers are sufficiently detailed to concretely analyse profits from several of Davenport's non-slaving businesses: ivory, wine, iron hoops, stockfish, and his investment in financial securities. Records are also extant, although less complete, for Davenport's trade in African produce, beads, iron bars, and his privateering speculation. By examining each of these concerns we will see how profits in non-slaving businesses compared to those in the slave trade, and therefore establish how crucial they were to Davenport's prosperity and success as a merchant.

The ivory trade was Davenport's largest non-slaving business. The Ivory Book details Davenport's trading from 1 January 1763 to 25 January 1785, at which time he quit the trade as he wound down his merchant house. Records for this twenty two year period are comprehensive and detail the date of transaction; the name of the buyer or seller; and the number weight and price of ivory bought and sold. Davenport also calculated his profits within the Ivory Book by comparing his purchases to his sales towards the end of a year, giving a sterling profit figure that he then converted into a percentage return. On 4 November 1766, for example, Davenport totalled up his ivory account and noted:

$£ 1415,6,6$ was appropriated for this concern [his purchases] from the $19 / 11 / 1765$ to the $4 / 11 / 1766$ is 11 Months \& 16 Days the Profits whereof appears to be $£ 105.14 .6$ which is 7.25 percent $^{100}$

Using Davenport's calculations in the Ivory Book, we can summarise his ivory investments and profits for the entire twenty-two year period (Table 11).

${ }^{100}$ Ivory Book 1763-1785, Liverpool, D/DAV/1, f.147 
The Ivory Book shows that Davenport reaped small but consistent profits from the ivory trade throughout the period 1763-1785. In 1763, when records commence Davenport was earning a 6.6 percent profit on his ivory sales, a margin that barely changed for the next eight years. However, a sharp increase in the cost of ivory impinged on Davenport's profits throughout the early 1770s, so that by 1775 he was forced to introduce a 2.5 percent commission on sales. This charge rescued Davenport's ivory profits from a further price increase during the American War, when the lack of slavers visiting the African coast severely limited supply. Despite the escalating price of ivory, Davenport maintained an average profit margin of 5.6 percent on his sales throughout his twenty-two years trading in the commodity, nearly half of the 10.9 percent average profit earned in slaving.

Table 11: William Davenport's Ivory Profits January 1763- January 1785

$\begin{array}{rrrrrrrr} & \begin{array}{r}\text { Length of } \\ \text { Period } \\ \text { Period }\end{array} & \begin{array}{r}\text { Weight of } \\ \text { Ivory } \\ \text { Sold }\end{array} & \begin{array}{r}\text { Ivory } \\ \text { Bought } \\ \text { (Lbs) }\end{array} & \begin{array}{r}\text { (£) } \\ \text { Ivory } \\ \text { Sold } \\ (\mathfrak{E})\end{array} & \begin{array}{r}\text { Profit } \\ (\mathfrak{E})\end{array} & \begin{array}{r}\text { Profit } \\ (\mathbf{\%})\end{array} & \begin{array}{r}\text { Ivory } \\ \text { Price } \\ \text { (Shgs }\end{array} \\ \text { per Lb) }\end{array}$

Source: Ivory Book 1763-1785, Liverpool, D/DAV/1

In addition to ivory, Davenport also dealt in ironware. From 1757 until 1779, the two waste books record Davenport vending $£ 10,500$ worth of iron bars — "voyage iron"- to Liverpool slaving vessels, approximately a tenth of his slaving investment in the same period. ${ }^{101}$ The waste books are less illuminating for Davenport's purchases of bars, as they detail only a handful of the consignments he brought in from London and Europe. These few entries record Davenport purchasing his iron bars for approximately ten percent less than the sale price. Using this figure, we can approximate Davenport’s returns from his bar business at $£ 955$, ten percent more than his purchases. A much more detailed account of Davenport's iron hoops trading is

${ }^{101}$ Waste Book 1745-1766, Liverpool, ODAV; Waste Book 1766-1780, Liverpool, D/DAV/2 
extant in the Ivory Book. The account shows that he purchased over the nine year period 1768-1777 fifty-two tons of hoops from London ironmongers for $£ 1,039 .{ }^{102}$ After on selling these hoops in Liverpool, and deducting freighting charges, Davenport earned $£ 1,245$ - a hefty profit margin of twenty-three percent.

Compared to ironware, Davenport's wine trading business proved to be a poor investment. He set up the "Wine, Rum \& Brandy Concern" with his brother Christopher in July 1764 and rented vaults in Harrington Street, Liverpool. ${ }^{103}$ The Davenport brothers imported $£ 2,800$ worth of European spirits in the first year of operation but did not make any profits until January 1769. When the business finally closed its doors in December 1773, Davenport had put $£ 2,144$ into the wine concern, returning him $£ 166$ in profits, or 7.8 percent. ${ }^{104}$ From 1767 to 1774 Davenport managed a second wine business with local brewer Thomas Gaskell. This concern achieved less impressive returns: for the first two years of operation the business turned a small profit, but by November 1774, when the partnership dissolved, the wine business recorded a loss of $£ 111 .{ }^{105}$ Looking at Davenport's two wine businesses together they made a somewhat paltry return of just $£ 50$ on an investment of $£ 3,150$.

Davenport's attempts to vend other commodities also gave poor returns. In 1769 and 1770, for example, Davenport attempted to diversify his business by selling seventeen tons of salted fish to Liverpool ships. After selling forty-three orders of fish for $£ 667$, Davenport found himself out of pocket by $£ 10 .{ }^{106}$ Although a minor financial loss, stockfish was a doubly poor investment because of the time involved in buying and selling the commodity, causing him to drop the fish trade. Davenport also lost money consigning goods to his network of associates. Between September 1759 and October 1769 he sent $£ 526$ worth of ginger, wax, ivory and crystal to European merchants who he hoped would on sell the items at a profit. His "adventure" made a loss of $£ 72$, and hence he gave up on the trade. ${ }^{107}$ Only Davenport's sale of four tons of pease and beef, purchased for $£ 100$, turned a $£ 10$ profit, although the slim return seems to have put him off any further speculation in that line of trade. ${ }^{108}$

\footnotetext{
102 "Iron Hoops Bought and Sold 1768-1777" in Ivory Book 1763-1785, Liverpool, D/DAV/1, ff.68-71

103 J. Gore, Gore's Liverpool Directory, (Liverpool: 1773), p.17

${ }^{104}$ Ledger Book 1763-1775, Liverpool, ODAV, ff.28,37,46,64

${ }^{105}$ Ibid., ff.41,65

${ }^{106}$ Waste book 1766-1780, Liverpool, D/DAV/2, ff.355-356

${ }^{107}$ Ledger Book 1763-1775, Liverpool, ODAV, f.18

${ }^{108}$ Waste Book 1766-1780, Liverpool, D/DAV/2, f.354
} 
Examining Davenport's trade in ivory, ironware, wine and various goods, together, none of the concerns gave particularly healthy returns compared to slaving. Ivory averaged a profit of 5.6 percent, wine made a negligible profit of 1.8 percent, and consigning and trading goods were time consuming and ultimately fruitless endeavours. Only his trade in ironware gave a profit exceeding that earned slave trade. We should remember, however, that iron bars and hoops - and indeed other items such as ivory and wine-were a low cost and high volume item. As such they required a large amount of time and effort in order to return a profit. For example, realising the $£ 275$ profit from his $£ 1,039$ speculation on iron hoops required Davenport to, over the course of nine years, make seventeen large purchases from his London suppliers and 148 small sales to Liverpool customers. A similar investment of $£ 1,039$ in the slave trade could, in unexceptional circumstances, make the same return in one to two years, and with much less effort.

Calculating Davenport's profits from beads, privateering and African produce, is more difficult than his other lines of business because of a paucity of sources. In each of these cases we have to draw from either incomplete accounts, or from scraps of information within Davenport's waste book and correspondence. However, if we are to build a complete picture of Davenport's trading concerns, we cannot afford to ignore his investment or profits from these businesses. As such, we will have to speculate on Davenport's profits using the best available evidence.

Beginning with Davenport's bead company, there is a cash book and ledger of sales extant for the firm. The latter volume records sales of $£ 39,048$ worth of beads in the period $1766-1770 .{ }^{109}$ It is reasonable to assume that the company sold the same volume of beads from 1770 until 1774, and perhaps half as many during the American War due to the drop off in the slave trade. If so, the company vended approximately $£ 100,000$ worth of beads to Liverpool's slaving fleet in the period 1766-1783. As a $1 / 7^{\text {th }}$ partner in the firm, Davenport's personal share of the sales would have been $£ 11,428$. What his share of the overheads was for these sales is unclear because of the lack of sources. However, if we use the eighteenth century merchant's benchmark of a ten percent profit margin, then Davenport's returns were $£ 1,038$ from the bead company.

${ }^{109}$ Account Book for Beads and Cowries 1766-1770, Liverpool, ODAV, f.153 
Davenport's bead trading profits were offset by losses arising from the collapse of the company's banker in 1772. Davenport had passed all of the bead company's bills through Joseph Wimpey until 20 June 1772 when he "stopt payment, and afterwards became a Bankrupt."110 After Wimpey's collapse, Davenport was forced to honor bills of exchange worth $£ 2,853$ on behalf of the company. ${ }^{111}$ As a result of Wimpey's collapse, Davenport sold the bead company to John Copeland by paying over to him $£ 6,426$ - the company's cash assets-from 1772 until $1774 .{ }^{112}$ Davenport appears to have remained as a share holder after the transfer as he wrote two letters in 1779 referring to "our Bead Company."113 In the meantime, Davenport set about recovering his $£ 2,853$ outstanding debt through Wimpey’s estate. After fifteen years, Davenport managed to recoup $£ 1,284$ of the debt, leaving him with a loss of $£ 1,569 .{ }^{114}$ When deducted from Davenport's imputed profits of $£ 1,298$, he therefore lost money from the bead company.

Davenport's investments in privateering during the latter years of the American War 1779-1781 are documented in his letters within the Ivory Book. In fitting out privateers, he hoped to profit from the capture of French, Spanish and Dutch prizes, the latter of which offered "fine pickings on the Seas as they are carriers for all the World." 115 In an attempt to take a share of the "pickings," Davenport equipped the Sturdy Beggar, a 160 ton privateer armed with sixteen cannon and crewed by one hundred men. ${ }^{116}$ In 1780 and 1781, his correspondence shows that he also took shares in five other privateers: Enterprize, Hector, Bee, Fly and Essex. ${ }^{117}$ Based upon Davenport's correspondence, in which he details his privateering shares, his investment in this small flotilla of "licensed pirates" came to approximately $£ 2,305$ (Table 12). ${ }^{118}$

\footnotetext{
110 “A Case No 5”, Liverpool, 21 January 1791, 920CHA/10/9 in Edward Chaffers Papers, MMM, Liverpool, England

111 Ibid.

112 The payments are noted in Bead Cash Book 1766-1776, Liverpool, D/DAV/2. The first payment was made on 3 August 1773 for $£ 1,667$ (f.39) and the last on 2 December 1780 (f.43).

${ }^{113}$ William Davenport to Charles Ford, Liverpool, 23 March 1779, D/DAV/1

${ }^{114}$ William Davenport to Edward Chaffers, Liverpool, 27 June 1790, 920CHA/10/9 in Edward Chaffers Papers, MMM, Liverpool, England; Davenport also lost $£ 2,194$ of his own money from Wimpey's collapse (Ibid.).

${ }^{115}$ William Davenport to Charles Ford, Liverpool, 27 January 1781, D/DAV/1

${ }^{116}$ Williams, Liverpool Privateers, p.253

${ }^{117}$ William Davenport to Anthony Kirwan, Liverpool, 22 July 1780, D/DAV/1; William Davenport to Charles Ford, Liverpool, 13 January 1781, D/DAV/1; William Davenport to Messrs Fletcher \& Goff, Liverpool 25 February 1781, D/DAV/1

118 "Licensed pirates" is Davenport's own description of privateers (William Davenport to William Begg, Liverpool, 16 March 1781, D/DAV/1).
} 
Table 12: Estimated Profits on Davenport's Privateering Ventures, 1779 to 1781

\begin{tabular}{|c|c|c|c|c|c|c|}
\hline Name & Year & Share & Cost $(\mathfrak{f})$ & Prizes (f) & Profits (£) & Profits (\%) \\
\hline Sturdy Beggar & 1779 & $1 / 24$ & 250 & 1,242 & 992 & $397 \%$ \\
\hline Enterprize & 1780 & $1 / 24$ & 350 & 1,035 & 685 & $195 \%$ \\
\hline Hector & 1781 & $1 / 32$ & 280 & 0 & -280 & $-100 \%$ \\
\hline Bee & 1781 & $1 / 16$ & 160 & 0 & -160 & $-100 \%$ \\
\hline Fly & 1781 & $1 / 16$ & 100 & 0 & -100 & $-100 \%$ \\
\hline \multirow[t]{2}{*}{ Essex } & 1781 & $1 / 4$ & 1,165 & 1,800 & 635 & $54 \%$ \\
\hline & & & 2,305 & 4,077 & 1,772 & $77 \%$ \\
\hline
\end{tabular}

Sources: William Davenport to Anthony Kirwan, Liverpool, 22 July 1780, D/DAV/1; William Davenport to Charles Ford, Liverpool, 13 January 1781, D/DAV/1; William Davenport to Messrs Fletcher \& Goff, Liverpool 25 February 1781, D/DAV/1; Williams, Liverpool Privateers, pp.253-258

Davenport's privateers had mixed luck on their cruises. The Fly was captured, and because Davenport had not "insured a penny" on her, he lost his $£ 100$ investment. ${ }^{119}$ Both the Hector and Bee also returned empty handed to Liverpool despite Davenport's hopes of "better success" than the Fly, and, as a result, his investment in these three vessels proved fruitless. ${ }^{120}$ His three other privateers achieved much better results. The Sturdy Beggar took three rich prizes laden with West India produce, before she "parted both cables in a gale of wind, drove on shore, and in ten minutes went entirely to pieces." ${ }^{\prime 21}$ The Enterprize also took three Spanish prizes, one of which was shared with another privateer. ${ }^{122}$ And on her cruise, the Essex captured

two Dutch Ships from St. Eustatia to Holland value at $£ 25,000$. The one a brig calld the Gouden Thee Boom Capt Harkout is arrived safe here worth $£ 10,000$ but the other called the Zee Fortune, Capn Wm Mitts, was dashd to pieces on the 19th Ulto, on the Rocks near Waxford \& all the crew perished ${ }^{123}$

\footnotetext{
${ }^{119}$ William Davenport to Charles Ford, Liverpool, 3 May 1781, D/DAV/1

${ }^{120}$ Williams, Liverpool Privateers, pp.253-258

121 The prizes were the St. Michael, Le Moissoner, and La Nostra Senora del Rosario (Ibid., p.253).

${ }^{122}$ Enterprize took the Courier, Le Vaillent and San Pedro, all in the space of a month (Ibid., p.249; William Davenport to Anthony Kirwan, Liverpool, 12 September 1780).

${ }^{123}$ William Davenport to Messrs Fletcher \& Goff, Liverpool, 25 February 1781, D/DAV/1
} 
Calculating Davenport's profits from these prizes is difficult because the ledger for his privateering investments in the period 1776-1787 is lost. However, there are scattered clues in the Davenport papers detailing some of his proceeds from privateering. We do know, for example, that the St. Michael, one of the Sturdy Beggar's prizes yielded William Davenport $£ 414$ as a $1 / 24^{\text {th }}$ shareholder in the vessel because there is an entry for it in the waste book. ${ }^{124}$ If the proceeds of the Sturdy Beggar's and Enterprize's other five captures matched those of the St. Michael, then Davenport's return from the two privateers was $£ 2,277 .{ }^{125}$ In the case of the Essex's prizes, the Gouden Thee Boom's cargo sold for $£ 6,000$ at auction. ${ }^{126}$ Davenport subsequently had to pay a London merchant who had shipped sugar on her $£ 1,613$, leaving just $£ 4,387$ to the Essex's investors. ${ }^{127}$ A letter from 1781 also reveals that the Essex's second prize Zee Fortuyn returned $£ 6,400$, as the underwriters disputed the original valuation of $£ 10,000 .{ }^{128}$ After deducting the captain and crew's third share, Davenport's share of the two prizes was probably around $£ 1,800$, a decent sum, but a fraction of their $£ 25,000$ value. Nevertheless, if the indicators in the Davenport papers are correct, then Davenport may have earned as much as $£ 4,077$ back from his initial investment of $£ 2,305$ in privateering, a clear profit of seventy-seven percent.

Like his privateering investments, we have to impute Davenport's profits from the African produce trade using his letters. Davenport does not state why he entered the produce trade in 1779 , but the most likely explanation is that he hoped to take advantage of a sharp increase in the price of ivory in Britain caused by the drop off in the slave trade. Moreover, African produce could be sold for short dated bills of exchange, relieving the acute liquidity crisis caused by the war. As a result, he purchased in September 1779 "a Brig call'd the William... burthern about 100 tons," and placed Captain William Begg, former surgeon of the Dalrymple, in command, who he instructed to sail to the Windward Coast and Old Calabar to barter his cargo

\footnotetext{
${ }^{124}$ Waste book 1766-1780, Liverpool, D/DAV/2, f.330

${ }^{125}$ One of the prizes has been halved to take account of the fact that the Enterprize split the proceeds with another privateer.

${ }^{126}$ Auction of the Entire Cargo of the Brig D'Goude Thee Boom, Liverpool, 3 April 1781 in Miscellaneous Ship Papers 1778-1834, Liverpool, D/DAV/4, ff.14-16

${ }^{127}$ William Davenport to Roger Altam Esq., Liverpool, 26 December 1783, D/DAV/1

${ }^{128}$ William Davenport to Joseph Denison, Liverpool, 19 June 1781, D/DAV/1
} 
for "Ivory \& as much Palm Oil as you can get"129 In the same month, Davenport sent the Hope, captained by Peter Potter, to purchase ivory and cam wood at Cameroon.

A July 1780 letter to Davenport's London insurance broker shows that the William's first voyage made a hefty profit of $£ 1,600$, of which Davenport received $£ 300$. The Hope, by contrast, was captured and as a result Davenport lost "£400 profits on the voyage." $" 130$ Given the potential profits to be made in produce trading, Davenport had the William swiftly re-fitted for a second trip to Old Calabar. In September 1781, Davenport wrote to Peter Potter, at sea in the privateer Essex, to inform him that Begg had arrived in Liverpool with

a very fine Cargo Consisting of upwards of 12 ton of Teeth 51 Punch of Palm Oyle \& 6 fine Negroes which is a very great Purchase for a Cargo of only $£ 1403,, 5,1$ and will clear the Owners above $£ 2000$ Sterling $^{131}$

After reaping a $£ 375$ profit on the William's second voyage, Davenport once again fitted out the vessel with a "very choice" cargo worth $£ 1,393 .{ }^{132}$ Although there are no further records of this third voyage, it is reasonable to assume that the venture also turned a profit given the William's previous success. If this was the case, Davenport's four produce ventures gave sizeable returns, with all but the Hope reaping exceptional profits (Table 13).

Table 13: Estimated Profits on Davenport's African Produce ventures, 1780 to 1782

\begin{tabular}{|c|c|c|c|c|c|c|}
\hline $\begin{array}{l}\text { Vessel } \\
\text { Name }\end{array}$ & $\begin{array}{l}\text { Captain's } \\
\text { Name }\end{array}$ & $\begin{array}{l}\text { Date of } \\
\text { Departure }\end{array}$ & $\begin{array}{l}\text { Date of } \\
\text { Return }\end{array}$ & Out (£) & In (£) & Profit (£) \\
\hline William & Begg, William & $5 / 1 / 1780$ & $10 / 10 / 1780$ & 400 & 700 & 300 \\
\hline Hope & Potter, Peter & $30 / 1 / 1780$ & Lost & 900 & 900 & 0 \\
\hline William & Begg, William & $16 / 12 / 1780$ & 9/9/1781 & 400 & 775 & 375 \\
\hline William & Comberbach, Peter & $27 / 12 / 1781$ & c. $26 / 9 / 1782$ & $\begin{array}{l}400 \\
\mathbf{2 . 1 0 0}\end{array}$ & $\begin{array}{l}775 \\
3150\end{array}$ & $\begin{array}{l}375 \\
1050\end{array}$ \\
\hline
\end{tabular}

Source: William Davenport to Anthony Kirwan, Liverpool, 6 October 1779, D/DAV/1; William Davenport to Captain William Begg, Liverpool, 5 January 1780, D/DAV/1; William Davenport to John Sowerby, Liverpool, 28 July 1780, D/DAV/1; William Davenport to Peter Potter, Liverpool, 4 October 1781, D/DAV/1; William Davenport to Captain Peter Comberbach, Liverpool, 27 December 1781, D/DAV/1; William Davenport to Peter Potter, Liverpool, 30 December 1781, D/DAV/1.

\footnotetext{
${ }^{129}$ William Davenport to Anthony Kirwan, Liverpool, 6 October 1779, D/DAV/1; William Davenport to Captain William Begg, Liverpool, 5 January 1780, D/DAV/1

${ }^{130}$ William Davenport to John Sowerby, Liverpool, 28 July 1780, D/DAV/1

${ }^{131}$ William Davenport to Peter Potter, Liverpool, 4 October 1781, D/DAV/1

132 William Davenport to Captain Peter Comberbach, Liverpool, 27 December 1781, D/DAV/1; William Davenport to Peter Potter, Liverpool, 30 December 1781, D/DAV/1
} 
It would appear, then, that Davenport's produce and privateering ventures in the period 1778-1782 both earned exceptional profits. Moreover, both trades brought in much needed liquidity, as prize cargoes and ivory traded for short dated bills of exchange, an important consideration compared to the long dated remittances that Davenport's slavers returned in the same period. However, these profits could only be made because of the unique trading conditions generated by the American War. Whilst a welcome windfall to Davenport, privateering and produce trading were short term investments made to take advantage of a fleeting opportunity.

After his retirement in 1786 Davenport shifted his trading capital into financial securities. A ledger book covering the period 1788-1797, shows that his pensions consisted of three different securities. Firstly, he owned government consols issued at $£ 22,500$ giving a three percent interest rate. Secondly, he earned four percent interest on his bank deposits. Thirdly, he lent $£ 14,000$ to a friend "on bond" at five percent, the legal maximum interest rate. ${ }^{133}$ Over the eight year period from 1 January 1788 until 1 January 1798 these assets netted him $£ 8,057$, a healthy 19.6 percent return on his original investment. This would seem to indicate that financial securities were much more fruitful investments than the slave trade.

There is, however, an important caveat that must be attached to the returns made in financial securities. Firstly, given the low interest rates of 3-5 percent in the eighteenth century, large profits could only be made on financial speculation with large sums of capital. If, upon his arrival in Liverpool, Davenport had placed his $£ 1,000$ start up capital in the bank, for example, he would have received an annual income of $£ 40$, barely more than an average working man’s wages. Moreover, Davenport could not influence this rate of return. At least in slave trading, Davenport could manipulate his market share and profits by associating with experienced partners and captains, cultivating African contacts, and developing efficient supply chains. No effort on Davenport's part could influence the interest he received on his financial securities.

In addition, money held in the bank was not safe from fluctuations in the market. Because the eighteenth century economy was built almost entirely on credit, the system was highly susceptible to cycles of boom and bust, resulting in the periodic

${ }^{133}$ Ledger Book 1788-1797, Liverpool, ODAV, ff.2,3,33,34,36,37,39,40 
credit crises Britain suffered in 1720, 1772 and 1793. As the guarantees of bills of exchange, the life blood of the system, banks were particularly susceptible to these financial panics. As we saw when we considered Davenport's bead trading, he had himself lost several thousand pounds when, during the crisis of 1772, his London banker Joseph Wimpey became bankrupt. The same may have happened had Davenport placed his carefully accrued fortune in Charles Caldwell's hands, a prominent Liverpool banker whose firm collapsed in the credit crisis of $1793 .{ }^{134}$

Eighteenth century consols were also susceptible to the market economy's vagaries because, as transferable instruments, they were traded on the open market. As a result, their value rose and fell based on the British government's fortunes, especially during wartime. Davenport, for example, purchased two tranches of consols, the first before 1788, and the second in 1790, a total investment of $£ 15,445{ }^{135}$ When Davenport died in 1797 , consols had plunged to forty-eight percent of their value, - the lowest in their history. ${ }^{136}$ As a result, Davenport's consols lost $£ 4,645$ of their value. Only the $£ 6,900$ he earned in interest on the securities saved them from producing a financial loss.

Davenport's financial investment portfolio, whilst far from being as safe and secure as it first appeared, still provided him with a sizeable pension, substantially bolstering his wealth between retirement and death. The $£ 8,057$ earned in financial speculation nearly matched his earnings from the sampled slaving voyages, and had Davenport not died in 1797, his wealth would have continued to increase proportionately. It would be easy to assume, then, that Davenport's wealth derived in large part from speculation on financial markets, not from the African slave trade. However, Davenport only had the capital to invest in securities because he had spent thirty-eight years accumulating capital as a slaving merchant. His profits from financial securities can thus be considered extensions of his slaving wealth, not independent earnings in of themselves.

\footnotetext{
${ }^{134}$ Hughes, Liverpool Banks \& Bankers, pp.86-87

${ }^{135}$ We cannot know for certain, but it would appear reasonable that he purchased government consols after drawing his capital out of the slave trade in 1785. In that year, consols were trading at 63 percent of their face value ("par"), and thus Davenport would have paid $£ 9,135$ for them (Ledger Book 17881797, Liverpool, ODAV, f.2). In January 1790, Davenport purchased a second tranche of consols for $£ 6,310$, with a par value of $£ 8,000$ (Ledger Book 1788-1797, Liverpool, ODAV, f.3). He held onto the consols until his death, when they passed to his relatives.

${ }^{136}$ Sidney Homer and Richard Eugene Sylla, A History of Interest Rates, (Hoboken: 2005), p.196;

Residuary Settlement of William Davenport, c.1797, Liverpool, BDM
} 
Table 14: William Davenport's business investments and profits, 1757-1797

\begin{tabular}{|c|c|c|c|c|c|c|c|}
\hline Trade & From & To & Yrs & $\begin{array}{l}\text { Purchases } \\
\text { (f) }\end{array}$ & Sales (f) & Profit (f) & $\begin{array}{l}\text { Profit } \\
(\%)\end{array}$ \\
\hline Slaving & 1757 & 1784 & 27 & 96,377 & 106,895 & 10,518 & $10.9 \%$ \\
\hline Ivory & 1763 & 1785 & 22 & 26,555 & 28,046 & 1,491 & $5.6 \%$ \\
\hline Bonds & 1785 & 1796 & 11 & 15,445 & 17,700 & 2,155 & $14.0 \%$ \\
\hline Beads & 1766 & 1783 & 17 & 14,025 & 14,285 & $-260 *$ & $-1.8 \%$ \\
\hline Mortgage & 1788 & 1796 & 2 & 14,000 & 15,050 & 1,050 & $7.5 \%$ \\
\hline Bank Interest & 1788 & 1796 & 8 & 13,051 & 17,867 & 4,816 & $36.9 \%$ \\
\hline Iron Bars & 1757 & 1779 & 22 & 9,545 & 10,500 & $955^{*}$ & $10.0 \%$ \\
\hline Wine & 1764 & 1774 & 10 & 3,150 & 3,204 & 54 & $1.7 \%$ \\
\hline Privateering & 1779 & 1781 & 2 & 2,305 & 4,077 & $1,722 *$ & $74.7 \%$ \\
\hline African produce & 1780 & 1781 & 2 & 2,100 & 3,150 & $1,050^{*}$ & $50.0 \%$ \\
\hline Iron Hoops & 1768 & 1777 & 9 & 1,046 & 1,337 & 291 & $27.8 \%$ \\
\hline Stockfish & 1769 & 1770 & 1 & 657 & 667 & -10 & $-1.5 \%$ \\
\hline Goods & 1759 & 1769 & 10 & 526 & 453 & -73 & $-13.9 \%$ \\
\hline \multirow[t]{2}{*}{ Pease and beef } & 1769 & 1770 & 1 & 127 & 136 & 9 & $7.1 \%$ \\
\hline & & & & 156,413 & 172,750 & 16,377 & $10.4 \%$ \\
\hline
\end{tabular}

Source: "Old” Davenport Papers, "New" Davenport Papers, Voyages Database

This chapter has examined William Davenport's business profits by focusing on the financial structure of his merchant house. We have seen that the ubiquity of credit transactions in the slave trade made necessary Davenport's participation in several other businesses. By dealing in non-slaving commodities, Davenport sourced a steady supply of small bills of exchange and broke down larger, more unwieldy bills sourced from slave sales. After demonstrating which commodities Davenport dealt in, we analysed profits from these various businesses.

Examining Davenport's investments from 1757 until his death in 1797 reveals that nearly two thirds of all his capital went into the slave trade, making it the backbone of his business (Table 14). It is clear that Davenport made such a heavy investment in the slave trade because it offered financial returns far in excess of alternative trades. Our extended sample of slaving ventures demonstrated that Davenport earned profits averaging 10.9 percent during his slaving career, and even higher returns averaging seventeen percent in the Cameroon region. By comparison, non-slaving businesses such as ivory, beads, wine and ironware either gave small, but consistent, returns, or could only turn a large profit margin on small sums of capital.

Slaving offered large profits because it was, by its nature, a high risk business. In venturing large sums of capital to Africa, Davenport hoped to earn a risk premium on his investment. For much of his career Davenport received that reward. Returns 
from Cameroon often exceeded twenty-five percent on the initial outlay and, as we saw with the voyage of the Hawke, could in exceptional circumstances more than double his capital. However, the slave trade had the potential to both make, and the break fortunes of its adventurers, as Davenport found with his voyages during the early years of the American War, such as that of the Badger. Davenport's career is therefore a good example of why eighteenth century commentators, such as former slaving captain John Newton, described the slave trade as "a game of chance," or even "a lottery.",137

Compared to the slave trade, trading in non-slaving commodities gave small but steady returns precisely because they involved very little risk on the part of their investors. Ivory and ironware never lost money and proved to be fruitful investments for twenty years. Similarly, Davenport's bank deposits and his money lending earned four or five percent interest because the chance of them being defaulted upon was slim. Only the bond market, privateering and African produce trading offered similar rewards to the slave trade, precisely because they were risky investments.

The correlation between risk and reward in Davenport's various investments explains why he chose to continue pursuing marginally profitable trades throughout his career. Because slaving returns fluctuated so wildly, Davenport needed a guaranteed stream of income to give his firm stability and maintain the liquidity of his company. In this way, Davenport's non-slaving businesses complemented his slaving business - the central hub of his merchant house. After his retirement, Davenport further built on his slaving profits by investing them in financial securities. Over the course of his career, then, the slave trade was central to Davenport's business and, therefore, his prosperity.

${ }^{137}$ Testimony of John Newton (PP 73 (1790), p.145) 


\section{Conclusion}

This thesis has investigated the business history of William Davenport, Liverpool slave trading merchant. It has shown that over a thirty-eight year career, Davenport invested $£ 127,000$ in slaving vessels, making him the seventh largest slave trading merchant of his generation. However, Davenport's real importance stemmed from the changes he wrought in the structure of the slave trade. In Africa, Davenport opened up the Cameroon market to slavers for the first time, extending the trade into a previously unexploited area of the Guinea coast. In America, Davenport marketed slaves to the Ceded Islands, principally Dominica and Grenada, former backwaters in the Atlantic economy turned productive sugar islands by the labour of enslaved Africans. In Liverpool, Davenport exploited the closing of the Isle of Man customs loop to make the town a centre of bead exports for the first time. Davenport was therefore both a specialist and an innovator, a merchant who extended and altered the character of the Liverpool slave trade.

As we saw in Chapter one, Davenport's highly specialised role marks him out as something of an oddity in the Liverpool merchant community. His singular concentration on the African slave trade kept him in obscurity within Liverpool's public sphere. Moreover, the long hours he spent in the counting house organising and financing slaving voyages came at the cost of marriage, children and ultimately a place in the annals of Liverpool history. Even amongst his fraternity of committed Africa men, he was a peculiarity. Slaving merchants such as William Gregson, and Thomas Leyland, managed to balance their commitment to the slave trade with a prominent place in the public sphere. Others, such as Davenport's good friend William Earle, turned the slave trade into a family business, with his sons taking over the helm of the company when the patriarch retired. Davenport, by contrast, eschewed all distractions from business.

Davenport's devotion to the slave trade sprung from his merchant apprenticeship to William Whaley. During his apprenticeship, Davenport developed a network of business contacts, and learned from Whaley how to fit out slaving vessels; esoteric knowledge reserved for only a select few merchants and captains. This training enabled Davenport to establish his own slaving firm at the age of just twentyseven, a feat achieved by few other merchants. Davenport's family background 
played an important role in this rapid progression from apprentice to merchant. With the support of his rich family, Davenport could afford the large amounts of start up capital needed to finance slaving vessels during the latter years of his apprenticeship, giving him a capital base from which to build his trading career. Moreover, the backing of his family gave him financial security, allowing him to ride out his early losses in the Gambia trade that would have crippled other merchants.

Perhaps it was this financial security that gave Davenport his enterprising character. When Davenport was finishing his apprenticeship there existed underexplored and under-exploited areas of the Guinea Coast such as Cameroon and Gabon. Chapter two showed how Davenport attempted to profit by these opportunities, by fitting out experimental ships to these regions. Once an opportunity presented itself at Cameroon, Davenport developed a complicated supply chain for beads, cowries and ironware to ensure that he stood to maximise his benefits from the region. Paralleling his Cameroon trading, Davenport simultaneously built a market share in the Old Calabar region by associating with a group of experienced captains with strong ties to the Efik middlemen in the region. By committing himself fully to these two markets Davenport established himself as the pre-eminent European slaving merchant in the eastern Bight of Biafra during the late 1760s and 1770s.

As we saw in Chapter three, Davenport committed himself to the slave trade because it offered profits in excess of his other businesses. Davenport's slaving ventures reaped an average 10.9 percent profit, a return that could be earned in other trades only on small sums of capital or in exceptional circumstances, such as the years 1778 to 1783 . Although non-slaving investments gave low returns relative to slaving, they were still of crucial importance to Davenport's company. Dealing in ivory, beads, wine, and ironware brought in a steady stream of small bills of exchange, made necessary by the prevalence of large bills of exchange in slave sales. Moreover, Davenport's other businesses acted as important parts of his slaving company, enabling him to supply goods to his own vessels, and secure a comparative advantage over his competitors. We should therefore not view Davenport's company as a number of separate businesses and concerns, but as a singular entity dedicated towards the slave trade, with each part of the business inter-connected to the other.

This specialist slaving company reaped Davenport substantial rewards: upon his death bed he possessed $£ 34,000$ - an estate greater than all but a handful of slaving merchants. Central to Davenport's financial success was the Cameroon 
market, an area that returned three quarters of his slaving profits. Davenport reaped these substantial profits from the region because his near monopoly on slave exports enabled his captains to purchase low priced, yet high "quality" enslaved Africans. Despite Davenport's best endeavours to cultivate a market share at Old Calabar, by comparison, his captains faced competition from too many other vessels and, as a result, his profits from that region were relatively poor. Davenport's returns from other markets on the Guinea Coast, where he possessed no market power at all, made negligible profits, or outright losses.

The regional pattern of Davenport's profits indicates that the capture of a dominant market share in an African market was the key to financial success in the Liverpool slave trade. In Davenport's case, he secure market dominance through the exploitation of a new African market. He is therefore an exemplar of the enterprising Liverpool merchants of the early eighteenth century, who built the town's slave trade by sending Guineamen to those areas of the coast unfrequented by Bristol and London traders. However, Davenport is less illustrative of slaving magnates such as William Boats, William Gregson and John Dawson, who participated in the high volume and well established Gold Coast- Jamaica slave trade. These rich merchants built their market share not through enterprise, but by sinking hundreds of thousands of pounds into slaving vessels and factories, giving them a comparative advantage through the sheer size of their companies, and the number of slaves they exported.

Davenport's slaving career therefore validates Joseph Inikori's thesis that the slave trade could be a profitable endeavour if a merchant gained a comparative advantage over his competitors. At the same time, though, Davenport's trading at regions outside Cameroon confirms that the slave trade was not an automatic road to riches. Davenport's 10.9 percent average slaving ventures profits conforms closely with Richardson (10.4 percent) and Anstey's (9.5 percent) estimates of slaving returns, demonstrating that nineteenth century historians and Eric Williams have probably overestimated the slave trade's profitability. Moreover, the losses Davenport suffered after the collapse in the bills of exchange system in 1775-1778 indicates that B.L. Anderson was right to highlight the importance of secure credit transactions to the profitability of the Liverpool slave trade. Although further research on Liverpool's slaving merchants is needed, Davenport's business history indicates that in order to profit by the slave trade, a merchant required commitment, large sums of money, and an acute business sense. 
Davenport's biography is thus a perfect case study of a slaving merchant who used his guile and entrepreneurial skill to create a niche for himself on the frontiers of the African slave trade. By directing every aspect of his company towards the slave trade, and devoting all of his time and financial resources to his business, Davenport was able to profit by the slave trade. Once those profits began to dwindle after 1783, he pulled his capital out of slaving and invested instead in financial securities. Through this business strategy, Davenport made his fortune. 


\section{Appendix A: Calculating Slaving Profit}

Calculating slave trading profits has been a contentious issue among historians. Two who have relied largely on the Davenport papers, David Richardson and Joseph Inikori, argue for different methods in calculating Davenport's profits. Therefore we must address the methodological difference in order to make our own venture profit calculations. Richardson published his methodology in his 1976 study "Profits in the Liverpool slave trade: the accounts of William Davenport, 1757-1784." Using only the ship accounts in the Old Davenport papers, Richardson calculated venture profits for seventy-four slaving voyages. ${ }^{1}$ By venture profits, Richardson meant the profit, or loss, made on a single voyage, calculated through the inputs and returns documented in ship accounts. He argued that in calculating venture profits, one could not simply take the figures in the Davenport papers at face value due to three important factors: the residual value of the slaving vessel; insurance premiums; and goods purchased on credit.

Firstly, one had to take into account the value of the slave ship's hull. When Davenport's slaving partnerships initially purchased vessels they went into the outlay in the ship book alongside the cost of the cargo. If the ship returned from sea and was used in subsequent voyages, the partners for the second voyage "bought" the vessel from the old partnership, factoring in depreciation. Because we do not know how eighteenth century slaving merchants assessed the residual value of the vessel, Richardson assumed a uniform write down of two-thirds of the vessel's initial outfitting cost, a not unreasonable assumption based on the sample of voyages available then. ${ }^{2}$

Secondly, insurance premiums had to be included in voyage costs. The ship books rarely detail insurance because it was typically left to the individual partners to purchase their own cover. As a result, Richardson had to apply an estimated premium based upon eighteenth century marine insurance rates. Assuming that Davenport insured every vessel, Richardson calculated these rates as 7.5 percent for a LiverpoolAfrica-America voyage in peacetime, rising to fifteen percent in wartime. If a vessel returned to Liverpool, Richardson also applied a rebate on the policy of 12.5 percent.

\footnotetext{
${ }^{1}$ Richardson, "The Accounts of William Davenport," pp.82-87

${ }^{2}$ Ibid., pp.70-71
} 
If, on the other hand, the vessel was wrecked or captured, he gave a return on the initial outlay of ninety-five percent. $^{3}$

Thirdly, and most importantly, payments for goods on credit had to be discounted in the outlay and receipts in bills of exchange discounted in the inset to convert their values to "cash or present values." Davenport and his partners paid for approximately a third to a half of the outfit in bills of exchange with credit terms of, Richardson argued, a typical length of twelve months. Whilst noting that the difference between cash and credit prices ranged from "5 to 20 percent or more", Richardson assumed a standard rate of five percent, in both peacetime and wartime trade. ${ }^{5}$ Turning to the inset, Richardson reduced the value of bills of exchange brought as slave remittances by five percent per annum, the standard discounting rate applied by the banks in Davenport's period.

Introducing these three variables - the ship, insurance, and credit discounts Richardson arrived at his "adjusted" profits formula (Table A1).

Table A1: David Richardson's “discounted" venture profits formula

\begin{tabular}{|l|l|}
\hline Outlay/ Debit & Inset/ Credit \\
\hline Original Outlay per Trading accounts & Original Inset per Trading accounts \\
\hline $\begin{array}{l}\text { + Residual value of ship from previous } \\
\text { voyage }\end{array}$ & $\begin{array}{l}\text { + Residual value of ship at end of voyage @ } \\
1 / 3 \text { of original Ship and Materials }\end{array}$ \\
\hline+ Insurance @ 5\% in peace OR 15\% in war & $\begin{array}{l}\text { + Insurance rebates or claims @ 12.5\% of } \\
\text { original premium OR 95 percent of ship } \\
\text { value if lost }\end{array}$ \\
\hline- Discount of 5\% on credit purchases & $\begin{array}{l}\text { Discount of 5\% per annum on remittances } \\
\text { in bills of exchange }\end{array}$ \\
\hline $\begin{array}{l}\text { Net Profit = ADJUSTED INSET - } \\
\text { ADJUSTED OUTLAY }\end{array}$ & \\
\hline
\end{tabular}

Source: Adapted from Richardson "The Accounts of William Davenport," pp.69-74

\footnotetext{
${ }^{3}$ Ibid., pp.71

${ }^{4}$ Ibid.,

${ }^{5}$ Ibid., p.72
} 
The effect of these adjustments was to increase net outlays on the seventy-four sampled voyages from $£ 324,000$ to $£ 362,000$; and increase the net returns from $£ 375,000$ to $£ 400,000$, producing an overall reduction in net profits of five percent. Based upon his calculation Richardson concluded that "average venture profits on the seventy-four voyages covered by the Davenport accounts was 10.5 percent." ${ }^{\prime 6}$ Taking account of the length of Africa voyages, many of which lasted more than a year, Richardson narrowed these profits to an annual return of 8.1 percent. However, this figure came with an important caveat "this rate of return was achieved largely as a result of two extraordinary voyages made by the Hawke in 1779 and 1780."7 With these two voyages removed, Davenport's slaving profits dropped to a rather less impressive 4.3 percent per annum.

Joseph Inikori contended in 1981 that Richardson's discounted model was flawed because it "introduced wide areas of possible inaccuracy." ${ }^{8}$ Inikori was correct to question the model, as Richardson makes several assumptions that are not borne out by Davenport's own method of calculating profits. The insurance rates he used, for example, were far too low in wartime. Whereas Richardson assumed a rate of 15 percent, the Davenport accounts show a figure almost double that amount in some years of the Seven Years and American wars. ${ }^{9}$ Moreover, during the latter war, Davenport occasionally chose not to take insurance out on several vessels, deeming the premiums to be too great. ${ }^{10}$ Finally, there is no evidence within the Davenport accounts of insurance rebates being included within profit calculations.

There are also problems with Richardson's write down on the ship. Table A2 summarises Davenport and Richardson's treatment of the King of Prussia's value for her seven voyages from 1767 to 1774. As the table shows, Richardson's two thirds write down is far too generous. After the first voyage Davenport reduced the value of the ship by fifty percent on the original outfitting cost; and on the second, third and fourth voyages by just over a third. After the fourth voyage, the value of the vessel

\footnotetext{
${ }^{6}$ Ibid., p.76

${ }^{7}$ Richardson, "The Accounts of William Davenport,"

${ }^{8}$ Inikori, "Market Structure and the Profits ", p 767

${ }^{9}$ For example, on the Calveley's 1758 voyage, it cost Davenport $£ 91$ to insure his $£ 264$ share in the vessel, a premium of 34.5 percent. Three years later, insuring his £509 share in the Eadith cost £161, a 31.7 percent premium (Trading Accounts of the Calveley, and Eadith, LRO, Liverpool England). See Appendix B for other examples of premiums exceeding 15 percent.

${ }^{10}$ In 1781, Davenport wrote to a St. Lucia contact that "The Underwriters askd 30Gs per ct on our Ship [Hawke] but we were determind to run our risque rather than be saddled with so such an extravagant premium \& very fortunate for us she arrived safe, by which we have savd near $£ 3000$ Stg premiums," (William Davenport to Messrs Craig \& Robinson, Liverpool, 21 October 1781).
} 
doubled, because she was upgraded to a ship rigged vessel, despite the outward cost of the vessel remaining the same. ${ }^{11}$

Table A2: Residual values of the King of Prussia's hull, 1767-1774

\begin{tabular}{|c|c|c|c|c|c|c|}
\hline & No. & $\begin{array}{l}\text { Ship } \\
\text { per DR }\end{array}$ & Out & $\begin{array}{l}\text { Ship Out per } \\
\text { Dav }\end{array}$ & $\begin{array}{l}\text { Ship In } \\
\text { per DR }\end{array}$ & Ship In per Dav \\
\hline 1767 & 1 & $\begin{array}{l}£ 1,469 \\
\text { Hull }\end{array}$ & $\begin{array}{l}\text { Outfit } \\
\text { ncludi }\end{array}$ & $\begin{array}{l}\text { ing costs were } \\
\lg £ 678 \text { for the }\end{array}$ & 490 & 750 \\
\hline 1769 & 2 & & 490 & 750 & 447 & 600 \\
\hline 1771 & 3 & & 447 & 600 & 472 & 600 \\
\hline 1772 & 4 & & 472 & 600 & 427 & 480 \\
\hline 1773 & 5 & & 427 & 480 & 443 & 960 \\
\hline 1774 & 6 & & 443 & 960 & 458 & 960 \\
\hline 1776 & 7 & & 458 & 960 & - & $\begin{array}{r}\text { Ship was sold for } \\
£ 420\end{array}$ \\
\hline
\end{tabular}

Source: David Richardson, "Profits in the Liverpool Slave Trade," pp.82-83; Trading Accounts of the King of Prussia 1767-1779, ODAV

In order to avoid the introduction of these errors, Inikori rightly argues that profit calculations be "strictly adapted to the way the traders themselves computed their profits." ${ }^{\prime 2}$ Discovering Davenport's methodology is made easy by two ledger books within the Old Davenport papers for the periods $1763-1775$ and $1788-1795 .{ }^{13}$ The ledgers contain accounts for Davenport's slaving partners, his suppliers and, most importantly for our purposes, his slaving voyages. Each vessel is devoted a single page, within which each individual voyage is given a section.

The 1769 voyage of the Dobson and her tender Fox's voyages to Old Calabar will illustrate the methodology Davenport used to determine his slaving returns (Table A3). Davenport entered the outlays on the voyage in the Debit column in May 1769, when the vessel sailed. Fox returned to Liverpool in April 1770, and the Dobson on 22 June $1770 .{ }^{14}$ The final returns on the voyage were not settled, however, until September 1770 when the bills of exchange were accepted for payment. ${ }^{15}$ Upon completing that last ledger entry and balancing the account, Davenport would see that

\footnotetext{
${ }^{11}$ The King of Prussia was a snow for her first three voyages (Voyages Database 91409-91410), and was then converted to ship sometime in 1772 (Voyages Database 91892).

${ }^{12}$ Inikori, "Market Structure and the Profits ", p.768

${ }^{13}$ Ledger Book 1763-1775, Liverpool, ODAV; Ledger Book 1788-1795, Liverpool, ODAV

${ }^{14}$ Voyages Database 91545 (Dobson) 91553 (Fox)

15 Trading Accounts of the Dobson and Fox 1769-1771, ODAV
} 
in the sixteen months from May 1769 to September 1770 his ship Dobson had made him $£ 103$, a venture profit of twenty-nine percent.

Table A3: "The Ship Dobson's $3^{\text {rd }}$ Voyage"

\begin{tabular}{|c|c|c|c|c|c|}
\hline \multicolumn{3}{|l|}{ Debit } & \multicolumn{3}{|l|}{ Credit } \\
\hline $\begin{array}{l}20 \text { May } \\
1769\end{array}$ & $\begin{array}{l}\text { To 1/24 of the Dobsons \& } \\
\text { Foxes Hull Cargo \& Outfit } \\
\text { as by Ship Book }\end{array}$ & $337,0,9$ & 17 Apr 1770 & $\begin{array}{l}\text { By } 1 / 24 \text { remittances } \\
\text { on Foxes Cargo }\end{array}$ & $177,9,4$ \\
\hline & $\begin{array}{l}\text { To £742,4,5 insurd on do to } \\
\text { Africa \& America \& from } \\
\text { Barbados }\end{array}$ & $21,11,7$ & 28 Sepr 1770 & $\begin{array}{l}\text { By } 1 / 24 \text { on the } 1^{\text {st }} \\
\text { Inset }\end{array}$ & $165,15,9$ \\
\hline & To $1 / 24$ of the Foxes Inset & $1,16,5$ & & $\begin{array}{l}\text { By } 1 / 24 \text { of the } 2^{\text {nd }} \\
\text { Inset }\end{array}$ & $72,2,9$ \\
\hline & $\begin{array}{l}\text { Balance Profits on this } \\
\text { voyage }\end{array}$ & $103,8,2$ & & $\begin{array}{l}\text { By } 1 / 24 \text { of the Last } \\
\text { accot }\end{array}$ & $48,9,1$ \\
\hline & & $£ 463,17$ & & & $£ 463,17$ \\
\hline
\end{tabular}

Source: Ledger Book 1763-1775, Liverpool, ODAV, f.34

Davenport's did not attempt to calculate an annual rate of return for each voyage. Nor did he do so elsewhere in the ship accounts, or in his business correspondence. Instead, Davenport considered only total venture, rather than annual rates of returns on his investments. He had good reason to do so. Although a slaving vessel might make a voyage in a year, the actual returns on the sale often took months to resolve, especially during wartime. Bills of exchange had to be taken to banks for acceptance, ivory and produce sold, and wages and fees settled. If there was wrangling over these transactions, the receipts might not clear until a year or more after the vessel's return. To give an extreme example, the Ann sailed in April 1779, but her account was not closed until nearly ten years later in January $1788 .{ }^{16}$ In reckoning profits, then, Davenport measured a voyage's length from when the ship sailed, until the receipts from the voyage were confirmed as good.

In calculating profits Davenport did not consider the "present" values of his credit transactions. As we saw when we examined the financial structure of Davenport's company, even the "cash" disbursements made on slaving vessels were

\footnotetext{
${ }^{16}$ Ledger Book 1788-1797, Liverpool, ODAV, f.8
} 
paid through interpersonal credit, or with short dated bills of exchange. Similarly, the vessel's receipts were also cleared through ledger accounts rather than through payments of cash between partners; credit transactions were not as simple as the ship accounts would lead us to believe. Moreover, as Richardson admitted, cash discounts for goods bought on credit varied markedly between five percent, to as much as twenty percent. Inikori makes a compelling argument supported by primary sources that higher discount rates were given to larger and more frequent customers. ${ }^{17}$ Assuming a uniform discount of five percent for cash could potentially ignore large differences in rates.

Whilst the discounting of credit transactions should, in ideal circumstances in which all information is available be performed, the financial organisation of Davenport's slaving company, coupled with the incompleteness of many of the venture accounts makes it a difficult and potentially error strewn exercise. To avoid these errors Davenport's methodology - the undiscounted model of calculating profits advocated by Inikori-has been used throughout this thesis. No attempt has been made to take account of the discounting of credit transactions, and annual profits have not been considered when examining individual ventures.

In order to maintain consistency with Davenport's methodology, informed assumptions have been made concerning the residual value of the slaving vessel at the end of the voyage, and the rates of insurance paid where they are not listed in the accounts. For the value of the ship, an initial write down of fifty percent from the outfitting cost has been given after the first voyage, followed by a thirty-three percent write down on the hull's residual value on every subsequent voyage. This rate has been taken from the average rates used by Davenport in the fully documented voyages. Insurance rates have been taken from Davenport's ledger book up to 1774, his insurance accounts, and from Davenport's correspondence with his broker from 1775 to 1783 . In keeping with Davenport's accounting treatment, only claims on insurances losses, rather than rebates on policies, have been considered. Using these criteria, an undiscounted venture profits formula has been used to calculate profits (Table A4).

${ }^{17}$ Inikori, "Market Structure and the Profits ", pp.762-763 
Table A4: Undiscounted venture profits formula

\begin{tabular}{|c|c|}
\hline Outlay/ Debit & Inset/ Credit \\
\hline $\begin{array}{l}\text { Original Outlay per Trading Accounts or } \\
\text { Ledger }\end{array}$ & $\begin{array}{l}\text { Original Inset per Trading Accounts or } \\
\text { Ledger }\end{array}$ \\
\hline $\begin{array}{l}+ \text { Residual value of ship from previous } \\
\text { voyage }\end{array}$ & $\begin{array}{l}+ \text { Residual value of ship at end of voyage @ } \\
1 / 2 \text { Ship and materials ( } 1^{\text {st }} \text { Voyage); } 2 / 3 \text { value } \\
\text { Ship at beginning of voyage (if subsequent } \\
\text { voyage) }\end{array}$ \\
\hline + Insurance per Davenport papers* & $\begin{array}{l}+ \text { Insurance claims per Davenport papers* @ } \\
95 \% \text { of value of ship and cargo }\end{array}$ \\
\hline$=$ OUTLAY & $=$ INSET \\
\hline INSET & \\
\hline
\end{tabular}

* Davenport papers includes the ship accounts, the accounts ledger, the bill book and Davenport's correspondence.

Source: Ledger Book 1763-1775, ODAV; Ledger Book 1788-1797, ODAV; Trading Accounts, ODAV; Ship Accounts 1768-1787, D/DAV/2; Personal Ledger 1763-1772, D/DAV/2; Voyages Database

Although Joseph Inikori used Davenport's methodology in his assessment of slaving profits, he also made several errors because he did not have access to both sets of Davenport papers. Most importantly, Inikori would not have known that Davenport was unable to recoup many of his slaving remittances during the American War of Independence. To give one example, for the 1776 voyage of the Badger, Inikori calculated a healthy venture profit of 32.9 percent using the undiscounted method. ${ }^{18}$ For the same voyage, Richardson calculated a less impressive 7.7 percent profit using his discounted model. ${ }^{19}$ However, calculating the profits using the undiscounted model, but with the benefit of the correspondence from the New papers, in combination with the ship book and the ledgers in the Old papers, gives a loss of twenty-six percent. It is thus clear that without using all of the available sources in the combined Old and New Davenport papers, any calculations of slaving profits are liable to errors.

\footnotetext{
${ }^{18}$ Ibid., p.771 n.86

${ }^{19}$ Richardson, "The Accounts of William Davenport," pp.82-83
} 


\section{Appendix B: William Davenport's slaving venture profits}

\begin{tabular}{|c|c|c|c|c|c|c|c|c|c|c|c|c|c|c|c|c|c|}
\hline VID & Name & $\mathbf{Y r}$ & Market & Share & Outfit & $\begin{array}{l}\text { WD's } \\
\text { Outfit }\end{array}$ & $\begin{array}{l}\text { Ship } \\
\text { Out }\end{array}$ & Insurance & $\begin{array}{l}\text { Other } \\
*\end{array}$ & $\begin{array}{l}\text { Total } \\
\text { OUT }\end{array}$ & Inset & $\begin{array}{l}\text { Ship } \\
\text { In }\end{array}$ & $\begin{array}{l}\text { Ins } \\
\text { Loss }\end{array}$ & $\begin{array}{l}\text { Other } \\
* *\end{array}$ & $\begin{array}{l}\text { Total } \\
\text { \# IN }\end{array}$ & 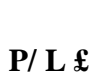 & $\begin{array}{l}\mathrm{P} / \mathrm{L} \\
\%\end{array}$ \\
\hline 90542 & Chesterfield & 1757 & Calabar & $1 / 8$ & 4,597 & 575 & 100 & 188 & 6 & 869 & 1,110 & 100 & & 20 & 1,230 & 361 & $42 \%$ \\
\hline 90745 & Calveley & 1758 & Cameroons & $1 / 6$ & 1,581 & 264 & & 91 & & 355 & 85 & & 310 & & 395 & 40 & $11 \%$ \\
\hline 90777 & Chesterfield & 1759 & Calabar & $1 / 16$ & 4,605 & 288 & 50 & 69 & 35 & 442 & & & 439 & 34 & 473 & 31 & $7 \%$ \\
\hline 90873 & Eadith & 1760 & Bassa & $1 / 12$ & 3,209 & 267 & & 75 & & 342 & 302 & 40 & & 23 & 365 & 23 & $7 \%$ \\
\hline 90858 & Tyrrell & 1761 & Calabar & $1 / 16$ & 6,276 & 392 & & 65 & 61 & 518 & 317 & 66 & & 3 & 386 & -133 & $-26 \%$ \\
\hline 90874 & Eadith & 1761 & Gambia & $1 / 6$ & 3,011 & 435 & 73 & 161 & & 670 & 3 & & 761 & & 764 & 94 & $14 \%$ \\
\hline 90906 & Union & 1762 & Bonny & $1 / 6$ & 4,980 & 830 & & 196 & & 1,026 & 691 & 117 & & 32 & 840 & -186 & $-18 \%$ \\
\hline 90937 & Plumper & 1762 & Windward Coast & $1 / 8$ & 3,802 & 475 & 111 & 199 & 13 & 798 & 621 & & 392 & 17 & 1,030 & 232 & $29 \%$ \\
\hline 91066 & Delight & 1763 & Sierra Leone & $1 / 8$ & 2,552 & 319 & 47 & 35 & 15 & 416 & 382 & 66 & & 22 & 470 & 54 & $13 \%$ \\
\hline 91017 & Dalrymple & 1763 & Calabar & $3 / 16$ & 2,592 & 486 & 138 & 72 & 51 & 747 & 816 & 84 & & 40 & 940 & 193 & $26 \%$ \\
\hline 91038 & Friendship & 1763 & Calabar & $1 / 12$ & 3,948 & 329 & 38 & 49 & 49 & 465 & 448 & 33 & & & 481 & 16 & $3 \%$ \\
\hline 90907 & Union & 1764 & Cameroons & $1 / 6$ & 2,940 & 490 & 116 & 69 & & 675 & 919 & 92 & & 4 & 1,015 & 340 & $50 \%$ \\
\hline 91067 & Delight & 1764 & Sierra Leone & $1 / 8$ & 2,984 & 373 & 66 & 41 & 27 & $\mathbf{5 0 7}$ & 452 & 50 & & 8 & 510 & 3 & $1 \%$ \\
\hline 91157 & Little Britain & 1764 & Porto Novo & $3 / 16$ & 2,233 & 407 & & 61 & 40 & 508 & 435 & & & 14 & 449 & -59 & $-12 \%$ \\
\hline 91213 & William & 1764 & Gambia & $1 / 6$ & 2,281 & 366 & & 42 & & 408 & 235 & & & & 235 & -173 & $-42 \%$ \\
\hline 91218 & Dalrymple & 1765 & Calabar & $1 / 8$ & 5,096 & 637 & 84 & 51 & 1 & 773 & 570 & 88 & & 28 & 686 & -87 & $-11 \%$ \\
\hline 91039 & Friendship & 1765 & New Calabar & $1 / 12$ & 4,680 & 390 & 33 & 33 & & 456 & 487 & 33 & & & 520 & 64 & $14 \%$ \\
\hline 91247 & Union & 1765 & Cameroons & $1 / 6$ & 3,546 & 591 & 92 & 41 & & 724 & 930 & 67 & & 9 & 1,006 & 282 & $39 \%$ \\
\hline 91256 & Active & 1765 & Calabar & $1 / 16$ & 7,968 & 498 & & 41 & & 539 & 397 & 46 & & & 443 & -96 & $-18 \%$ \\
\hline 91081 & Henry & 1765 & Cameroons & $1 / 8$ & 2,241 & 280 & 30 & 40 & 6 & 356 & 396 & 38 & & 8 & 442 & 86 & $24 \%$ \\
\hline 91219 & Dalrymple & 1766 & Calabar & $5 / 32$ & 5,766 & 901 & 88 & 72 & 22 & 1,083 & 1,467 & & & 8 & 1,475 & 392 & $36 \%$ \\
\hline 91158 & Little Britain & 1766 & Calabar & $5 / 32$ & & & & & & & & & & & & & \\
\hline 91313 & Friendship & 1766 & New Calabar & $1 / 12$ & 4,140 & 345 & 33 & 13 & & 391 & 329 & & & & 329 & -62 & $-16 \%$ \\
\hline 91214 & William & 1766 & Cameroons & $1 / 12$ & 2,169 & 167 & & 28 & & 195 & 221 & & & 2 & 223 & 28 & $14 \%$ \\
\hline 91354 & Union & 1767 & Cameroons & $1 / 6$ & 4,878 & 813 & 53 & 52 & & 918 & 758 & 250 & & 20 & 1,028 & 110 & $12 \%$ \\
\hline 91360 & Dobson & 1767 & Calabar & $3 / 32$ & 7,104 & 666 & & 66 & & 732 & 239 & & 106 & & 345 & -387 & $-53 \%$ \\
\hline 91395 & Good Intent & 1767 & Calabar & $3 / 32$ & & & & & & & & & & & & & \\
\hline 91082 & Henry & 1767 & Cameroons & $1 / 8$ & 1,700 & 213 & 38 & 14 & & 265 & 136 & 38 & & 16 & 190 & -75 & $-28 \%$ \\
\hline 91408 & King of Prussia & 1767 & Cameroons & $1 / 8$ & 3,610 & 451 & & 29 & & 480 & 551 & 94 & & 6 & 651 & 171 & $36 \%$ \\
\hline 91427 & Neptune & 1768 & Calabar & $3 / 16$ & 1,399 & & & & & & & & & & & & \\
\hline
\end{tabular}




$\begin{array}{llll}91220 & \text { Dalrymple } & 1768 & \text { Calabar } \\ 91428 & \text { Plumper } & 1768 & \text { Benin } \\ 91215 & \text { William } & 1768 & \text { Cameroons } \\ 91355 & \text { Union } & 1768 & \text { Cameroons } \\ 91545 & \text { Dobson } & 1769 & \text { Calabar } \\ 91553 & \text { Fox } & 1769 & \text { Calabar } \\ 91083 & \text { Henry } & 1769 & \text { Cameroons } \\ 91409 & \text { King of Prussia } & 1769 & \text { Cameroons } \\ 91573 & \text { Hector } & 1769 & \text { Calabar } \\ 91594 & \text { Andromache } & 1769 & \text { Calabar } \\ 91585 & \text { William } & 1769 & \text { Cameroons } \\ 91429 & \text { Plumper } & 1769 & \text { Benin } \\ 91221 & \text { Dalrymple } & 1770 & \text { Calabar } \\ 91653 & \text { Swift } & 1770 & \text { Calabar } \\ 90958 & \text { Kildare } & 1770 & \text { Bonny } \\ 91643 & \text { True Blue } & 1770 & \text { Benin } \\ 91356 & \text { Union } & 1770 & \text { Cameroons } \\ 91700 & \text { Dobson } & 1770 & \text { Calabar } \\ 91621 & \text { Fox } & 1770 & \text { Calabar } \\ 91574 & \text { Hector } & 1771 & \text { Calabar } \\ 91595 & \text { Andromache } & 1771 & \text { Calabar } \\ 91430 & \text { Plumper } & 1771 & \text { Bonny } \\ 91694 & \text { Patty } & 1771 & \text { Windward Coas } \\ 91702 & \text { Lord Cassils } & 1771 & \text { Calabar } \\ 91743 & \text { May } & 1771 & \text { Calabar } \\ 91410 & \text { King of Prussia } & 1771 & \text { Cameroons } \\ 91752 & \text { Dalrymple } & 1771 & \text { Calabar } \\ 91790 & \text { Swift } & 1771 & \text { Calabar } \\ 91803 & \text { Fox } & 1771 & \text { Cameroons } \\ 91892 & \text { King of Prussia } & 1772 & \text { Cameroons } \\ 91864 & \text { May } & 1772 & \text { Calabar } \\ 91791 & \text { Swift } & 1772 & \text { Calabar } \\ 91753 & \text { Dalrymple } & 1772 & \text { Calabar } \\ 91837 & \text { Dreadnought } & 1772 & \text { Calabar }\end{array}$

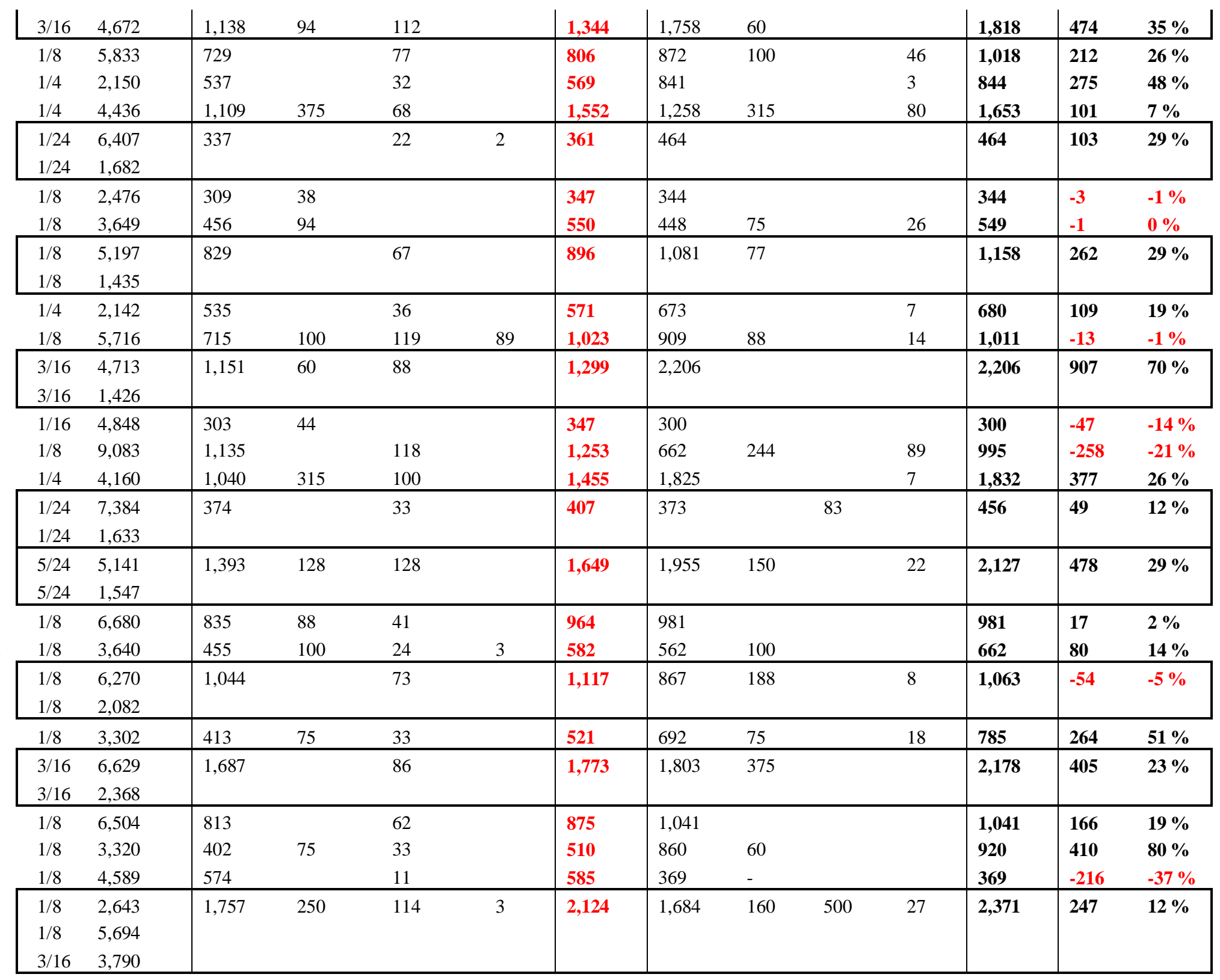




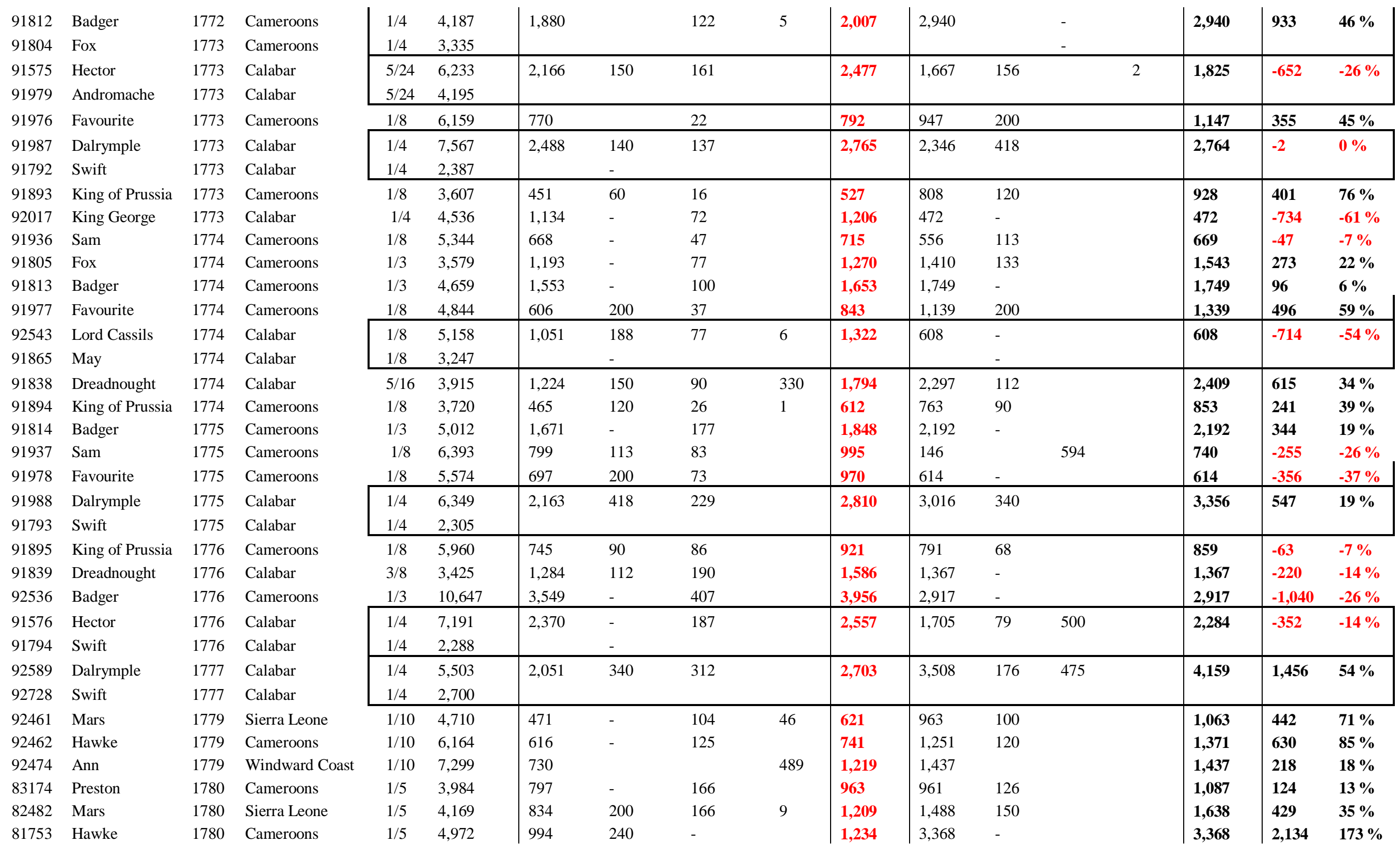




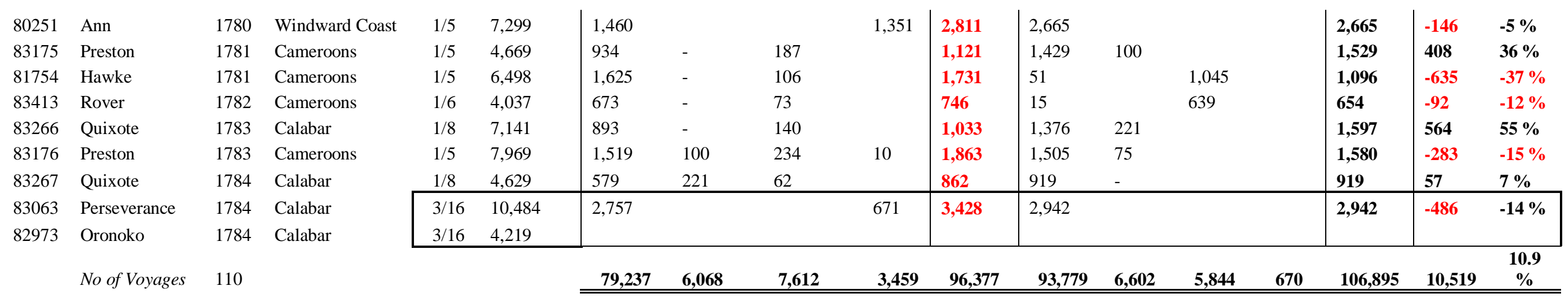

Source: Ledger Book 1763-1775, ODAV; Ledger Book 1788-1797, ODAV; Trading Accounts, ODAV; Ship Accounts 1768-1787, D/DAV/2; Personal Ledger 1763-1772, D/DAV/2; Voyages Database.

Note: Ventures grouped by a box are ship and tender voyages. In keeping with Davenport's methodology they have been treated as a single venture for the purpose of calculating profits.

* For the outward investment other constitutes small items of expenditure incurred clearing vessels into port. The large "other" balances showing for the Ann's two voyages, and the ship and tender voyage of the Perseverance and Oronoko stem from a lack of information in Davenport's ledger. The entry for the two vessels has only total inward and outward investment and, therefore, it is impossible to ascertain what the charges were for insurance or the ship. The outfitting cost of the three ventures has been estimated using Anstey's per tonnage estimation.

** For the inward return, other constitutes discounts received on trades goods not entered when the vessel sailed, and returned goods. 


\section{Bibliography}

\section{PRIMARY SOURCES}

\section{Merchant Papers}

“Earle Family Papers,” Merseyside Maritime Museum, Liverpool, England.

"Papers Relating to the Estate of Edward Chaffers," Liverpool Record Office, Liverpool England

“The Papers of William Davenport \& Co. (1745-1797)," Keele University Library, Staffordshire, England.

“William Davenport Papers,” Merseyside Maritime Museum, Liverpool England.

\section{Editted Primary Sources}

Donnan, Elizabeth, Documents Illustrative of the History of the Slave Trade to America: The Border Colonies and Southern Colonies, 4 vols., vol. 4, (Buffalo, NY: 2002)

, Documents Illustrative of the History of the Slave Trade to America: The Eighteenth Century, 4 vols., vol. 2, (Buffalo, NY: 2002)

Lambert, Sheila, House of Commons Sessional Papers of the Eighteenth Century, (Wilmington: 1975)

\section{Books and Pamphlets}

Adams, John, Sketches Taken During Ten Voyages to Africa, between the Years 1786 and 1800, (London: 1821)

- Remarks on the Country Extending from Cape Palmas to the River Congo, (London: 1823)

Anon., A Treatise Upon the Trade from Great-Britain to Africa; Humbly Recommended to the Attention of Government by an African Merchant, (London: 1772)

- "West Africa," (Unpublished, c.1784)

Arthy, Elliot, Introductory Observations in Favour of the African Slave Trade, (Liverpool: 1804)

Bailey, William, Bailey's List of Bankrupts, Dividends, and Certificates, from the Year 1772, to 1793, (London: 1794)

Clarkson, Thomas, An Essay on the Impolicy of the African Slave Trade: In Two Parts, (London: 1788)

- The Substance of the Evidence of Sundry Persons on the Slave Trade, (London: 1789)

- The History of the Rise, Progress, and Accomplishment of the Abolition of the African Slave-Trade by the British Parliament, (London: 1808)

Enfield, William, An Essay Towards the History of Leverpool, (London: 1774)

Falconbridge, Alexander, An Account of the Slave Trade on the Coast of Africa, (London: 1788)

Gore, J., The Liverpool Directory for the Year 1766: Containing an Alphabetical List 
of the Merchants, Tradesmen, and Principal Inhabitants of the Town of Liverpool with Their Respective Addresses, (Liverpool: 1766)

, Gore's Liverpool Directory, (Liverpool: 1773)

, Gore's Liverpool Directory for the Year 1777, (Liverpool: 1777)

, Gore's Liverpool Directory, (Liverpool: 1781)

, Gore's Liverpool Directory, (Liverpool: 1790)

Johnson, Samuel, A Dictionary of the English Language, (London: 1755)

Moss, Dr William, The Liverpool Guide; Including a Sketch of the Environs with a Map of the Town, 2nd (Liverpool: 1797)

Roscoe, William, A General View of the African Slave-Trade, (London: 1788)

Schroeder, Henry, Three Years' Adventures of a Minor, (Leeds: 1822)

Smith, Adam, An Inquiry into the Nature and Causes of the Wealth of Nations, (London: 1776).

Stanfield, James Field, Observations on a Guinea Voyage, (London: 1788)

Williamson, R., The Liverpool Memorandum Book; or Gentleman's, Merchant's and Tradesman's Daily Pocket Journal, (Liverpool: 1753)

Wosencraft, Charles, The Liverpool Directory, for the Year 1790, (Liverpool: 1790)

\section{SECONDARY SOURCES}

\section{Books}

Anon., Liverpool and Slavery: An Historical Account of the Liverpool-African Slave Trade. Was It the Cause of the Prosperity of the Town? By a Genuine Dicky Sam, (Liverpool: 1884)

Anstey, Roger, The Atlantic Slave Trade and British Abolition 1760-1810, (London: 1975)

Aspinall, Clarke, Liverpool a Few Years since by an Old Stager, (Liverpool: 1885)

Austen, Ralph A., and Jonathan Derrick, Middlemen of the Cameroons Rivers: The Duala and Their Hinterland, C.1600-C.1960, African Studies Series, (Cambridge; New York: 1999)

Baines, Edward History of the County Palatine and Duchy of Lancaster, vol. 1, (London: 1886)

Baines, Thomas, History of the Commerce and Town of Liverpool and of the Rise of Manufacturing Industry in the Adjoining Counties, (London: 1852)

Barker, T.C., and J.R. Harris, St. Helens: A Merseyside Town in the Industrial Revolution, (London: 1959)

Behrendt, Stephen D., A.J. Latham, and David Northrup, The Diary of Antera Duke: An Eighteenth-Century African Slave Trader (New York: Forthcoming)

Bourne, H.R. Fox, English Merchants: Memoirs in Illustration of the Progress of British Commerce, 2 vols., vol. 2, (London: 1866)

Brooke, Richard, Liverpool as It Was During the Last Quarter of the Eighteenth Century, 1775 to 1800, (Liverpool: 1853)

Burke, Sir Bernard, A Genealogical and Heraldic Dictionary of the Landed Gentry of Great Britain and Ireland, 4th 2 vols., vol. 1, (London: 1862)

Curtin, Philip, Economic Change in Precolonial Africa: Senegambia in the Era of the Slave Trade, (Madison: 1975)

Davies, C Stella, The Agricultural History of Cheshire 1750-1850, (Manchester: 1960)

Dignan, John, The Slave Captain; a Legend of Liverpool, (London: 1847) 
Gauci, Perry, The Politics of Trade: The Overseas Merchant in State and Society, 1660-1720, (Oxford: 2001)

Giles, Keith, The Bromley-Davenport Papers: The Tenants of a Cheshire Estate 1700-1900, (Auckland: 1999)

Hughes, John, Liverpool Banks and Bankers, 1760-1837: A History of the Circumstances Which Gave Rise to the Industry, and of the Men Who Founded and Developed It, (Liverpool: 1906)

Hyde, Francis Edwin, Liverpool and the Mersey: An Economic History of a Port, 1700-1970, (Newton Abbot: 1971)

Hyland, Peter, The Herculaneum Pottery: Liverpool's Forgotten History, (Liverpool: 2005)

Inikori, J. E., Africans and the Industrial Revolution in England: A Study in International Trade and Economic Development, (Cambridge: 2002)

Muir, Ramsay, Bygone Liverpool, (Liverpool: 1908)

Namier, Lewis, and John Brooke, The History of Parliament: The House of Commons, 1754-1790: Members a-J, 3 vols., vol. 2, (London: 1964)

Picton, James A., Memorials of Liverpool, Historical and Topographical, Including a History of the Dock Estate, 2 vols., vol. 2, (London: 1873)

- Selections from the Municipal Archives and Records of the City of Liverpool from Ad 1700 to the Passing of the Municipal Reform Act, 1835, vol. 2, (Liverpool: 1886)

Price, Jacob M., Capital and Credit in British Overseas Trade: The View from the Chesapeake, 1700-1776, (Cambridge, Mass.: 1980)

Rawley, James A., London, Metropolis of the Slave Trade, Shades of Blue and Gray Series, (Columbia: 2003)

, and Stephen D. Behrendt, The Transatlantic Slave Trade: A History, Rev. (Lincoln: 2005)

Schwarz, Suzanne, Slave Captain: The Career of James Irving in the Liverpool Slave Trade, 2nd rev. (Liverpool: 2008)

Sedgewick, Romney, The History of Parliament: The House of Commons, 17151754: Members E-Y, 3 vols., vol. 3, (London: 1970)

Sheridan, Richard B., Sugar and Slavery: An Economic History of the West Indies, 1623-1775, 2nd (Kingston: 1974)

Sparks, Randy J., The Two Princes of Calabar: An Eighteenth-Century Atlantic Odyssey, (Cambridge, Mass.: 2004)

Stein, Robert, The French Slave Trade in the Eighteenth Century: An Old Regime Business (Madison: 1979)

Stonehouse, Recollections of Old Liverpool by a Nonagerian, (Liverpool: 1836)

Thomas, Hugh, The Slave Trade: The Story of the Atlantic Slave Trade, 1440-1870, (New York: 1997)

Troughton, Thomas, History of Liverpool, (Liverpool: 1810)

Wallace, A General and Descriptive History of the Ancient and Present State, of the Town of Liverpool, (Liverpool: 1795)

Wilkins, Francis, Manx Slave Traders, (Kidderminster: 1999)

Williams, Eric, Capitalism and Slavery, (London: 1989)

Williams, Gomer, History of the Liverpool Privateers and Letters of Marque: With an Account of the Liverpool Slave Trade, 1744-1812, (Liverpool: 1897)

\section{$\underline{\text { Book Sections }}$}


Anderson, B.L., "The Lancashire Bill System and Its Liverpool Practitioners: The Case of a Slave Merchant," in Trade and Transport: Essays in Economic History in Honour of T.S. Willan, eds. W.H. Chaloner and B.M. Ratcliffe (Manchester: 1977), pp.59-97.

, "Financial Institutions and the Capital Market on Merseyside in the Eighteenth and Nineteenth Centuries," in Commerce, Industry and Transport: Studies in Economic Change on Merseyside, eds. B. L. Anderson and P. J. M. Stoney (Liverpool: 1983), pp.26-53.

Austen, Ralph A., "Slave Trade and Memory on the Periphery of the Nigerian Hinterland" in Ports of the Slave Trade (Bights of Benin and Biafra): Papers from a Conference of the Centre of Commonwealth Studies, eds. Robin Law and Silke Strickrodt (Stirling: 1998), pp.75-103.

Behrendt, Stephen D., "Human Capital in the British Slave Trade," in Liverpool and Transatlantic Slavery, eds. David Richardson, Suzanne Schwarz and Anthony Tibbles (Liverpool: 2007), pp.66-97.

Drake, B.K, "The Liverpool-African Voyage C. 1790-1807: Commercial Problems," in Liverpool, the African Slave Trade, and Abolition, ed. Roger Anstey (Liverpool: 1976), pp.126-156.

Elder, Melinda, "The Liverpool Slave Trade, Lancaster and Its Environs," in Liverpool and Transatlantic Slavery, eds. David Richardson, Suzanne Schwarz and Anthony Tibbles (Liverpool: 2007), pp.118-137.

Johnson, Marion, "The Atlantic Slave Trade and Economy of West Africa," in Liverpool, the African Slave Trade, and Abolition, ed. Roger Anstey (Liverpool: 1976), 1-13.

Kermode, Jenny, Janet Hollinshead, and Malcolm Gratton, "Small Beginnings: Liverpool 1207-1680," in Liverpool 800: Culture, Character and History, ed. John Belchem (Liverpool: 2006), pp.59-112.

Longmore, Jane, "Civic Liverpool: 1680-1800," in Liverpool 800: Culture, Character and History, ed. John Belchem (Liverpool: 2006), pp.113-169.

, "'Cemented by the Blood of a Negro?' the Impact of the Slave Trade on Eighteenth Century Liverpool," in Liverpool and Transatlantic Slavery, eds. David Richardson, Suzanne Schwarz and Anthony Tibbles (Liverpool: 2007), pp.227-251.

Lovejoy, Paul E., and David Richardson, "Letters of the Old Calabar Slave Trade, 1760-1789," in Genius in Bondage: Literature of the Early Black Atlantic eds. Vincent Carretta and Phillip Gould (Lexington: 2001), pp.89-115.

Mathias, Peter, "Risk, Credit and Kinship in Early Modern Enterprise," in The Early Modern Atlantic Economy, eds. John J. McCusker and Kenneth Morgan (Cambridge: 2000), pp.15-35.

Morgan, Kenneth, "Liverpool's Dominance in the British Slave Trade, 1740-1807," in Liverpool and Transatlantic Slavery, eds. David Richardson, Suzanne Schwarz and Anthony Tibbles (Liverpool: 2007), pp.14-42.

Pares, Richard, "A London West India Merchant House 1740-1769," in Essays Presented to Sir Lewis Namier, eds. Richard Pares, AJP Taylor and Lewis Namier (London: 1956), pp.75-107.

Pope, David, "The Wealth and Social Aspirations of Liverpool's Slave Merchants of the Second Half of the Eighteenth Century," in Liverpool and Transatlantic Slavery, eds. David Richardson, Suzanne Schwarz and Anthony Tibbles (Liverpool: 2007), pp.164-226.

Price, Jacob M., "Credit in the Slave Trade and Plantation Economies," in Slavery and 
the Rise of the Atlantic System, ed. Barbara L. Solow (Cambridge: 1994), pp.293-339.

Richardson, David, "Profits in the Liverpool Slave Trade: The Accounts of William Davenport," in Liverpool, the African Slave Trade, and Abolition, eds. Roger Anstey and Paul Hair (Liverpool: 1976), pp.60-90.

, "West African Consumption Patterns and Their Influence on the EighteenthCentury English Slave Trade," in The Uncommon Market: Essays in the Economic History of the Atlantic Slave Trade, eds. H.A Gemery and Jan Hogendorn (London: 1979), pp.303-330.

Walsh, Lorena S., "Liverpool's Slave Trade to the Colonial Chesapeake: Slaving on the Periphery," in Liverpool and Transatlantic Slavery, eds. David Richardson, Suzanne Schwarz and Anthony Tibbles (Liverpool: 2007), pp.98117.

\section{Theses}

Jones, Denise M., "The Business Organisation of the Liverpool Slave Trade in the Eighteenth Century: A Case Study of Robert Bostock," MA, University of Liverpool, 2006.

Refford, Brian, "The Bonds of Trade: Liverpool Slave Traders, 1695-1775," PhD, Lehigh University, 2005.

\section{$\underline{\text { Journal Articles }}$}

Akinjogbin, I.A., "Archibald Dalzel: Slave Trader and Historian of Dahomey", The Journal of African History, vol. 7, no. 1, (1966), pp. 67-78.

Alpern, Stanley B., "What Africans Got for Their Slaves: A Master List of European Trade Goods", History in Africa, vol. 22, (1995), pp. 5-43.

Anderson, B.L., "Money and the Structure of Credit in the Eighteenth Century", Business History, vol. 12, no. 2, (1970), pp. 85-101.

, and David Richardson, "Market Structure and Profits of the British African Trade in the Late Eighteenth Century: A Comment", The Journal of Economic History, vol. 43, no. 3, (Sep. 1983), pp. 713-721.

, "Market Structure and Profits of the British African Trade in the Late Eighteenth Century: A Rejoinder Rebutted", The Journal of Economic History, vol. 45, no. 3, (Sep. 1983), pp. 705-707.

Barker, T.C., "Lancashire Coal, Cheshire Salt and the Rise of Liverpool", Transactions of the Historic Society of Lancashire and Cheshire, vol. 103, (Feb 1951), pp. 83-101.

Carrington, Selwyn H.H., "The American Revolution and the British West Indies' Economy", Journal of Interdisciplinary History, vol. 17, no. 4, (1987), pp. 823-850.

Cavendish, Richard, "Capesthorne Hall, Cheshire", History Today, vol. 47, no. 12, (Dec. 1997), pp. 62-63.

Clemens, Paul, "The Rise of Liverpool, 1665-1750", The Economic History Review, vol. 29, no. 2, (May 1976), pp. 211-225.

Darity, William (Jr), "Profitability of the British Trade in Slaves Once Again", Explorations in Economic History, vol. 26, (1989), pp. 380-384.

Doerflinger, Thomas M., "Commercial Specialisation in Philadelphia's Merchant Community, 1750-91", The Business History Review, vol. 57, no. 1, (Spring 
1983), pp. 20-49.

Dumbell, Stanley, "The Profits of the Guinea Trade", Economic History Supplement to Economic Journal, vol. 2, (1931), pp. 254-257.

Eltis, David, and Stanley L. Engerman, "The Importance of Slavery and the Slave Trade to Industrializing Britain", The Journal of Economic History, vol. 60, no. 1, (Mar. 2000), pp. 123-144.

Evans, Chris, Owen Jackson, and Goran Ryden, "Baltic Iron and the British Iron Industry in the Eighteenth Century", The Economic History Review, vol. 55, no. 4, (Nov. 2002), pp. 642-665.

Gemery, H.A, Jan Hogendorn, and Marion Johnson, "Evidence on English/ African Terms of Trade in the Eighteenth Century", Explorations in Economic History, vol. 27, (1990), pp. 157-177.

Grenfell, George, "The Cameroons District, West Africa", Proceedings of the Royal Geographical Society and Monthly Record of Geography, vol. 4, no. 10, (Oct. 1882), pp. 585-595.

Guillaume, Daudin, "Profitability of Slave and Long-Distance Trading in Context: The Case of Eighteenth-Century France", Journal of Economic History, vol. 66, (2004), pp. 144-171.

Hyde, Francis Edwin, Bradbury B. Parkinson, and Sheila Mariner, "The Nature and Profitability of the Liverpool Slave Trade", The Economic History Review, vol. 5, no. 3, (1953), pp. 368-377.

Inikori, J.E., "The Import of Firearms into West Africa 1750-1807: A Quantitative Analysis", The Journal of African History, vol. 18, no. 3, (1977), pp. 339-368. "Market Structure and the Profits of the British African Trade in the Late Eighteenth Century", The Journal of Economic History, vol. 41, (Dec. 1981), pp. 745-776.

"Market Structure and the Profits of the British African Trade in the Late Eighteenth Century: A Rejoinder", The Journal of Economic History, vol. 43, no. 3, (Sep. 1983), pp. 723-728.

"Market Structure and Profits: A Further Rejoinder", The Journal of Economic History, vol. 45, no. 3, (Sep. 1985), pp. 708-711.

Johnson, Marion, "By Ship or by Camel: The Struggle for the Cameroons Ivory Trade in the Nineteenth Century", Journal of African History, vol. 19, no. 4, (1978), pp. 539-549.

Klein, Herbert S., "The English Slave Trade to Jamaica, 1782-1808", The Economic History Review, vol. 31, no. 1, (Feb. 1978), pp. 25-45.

Littler, Dawn, "The Earle Collection: Records of a Liverpool Family of Merchants and Shipowners", Transactions of the Historic Society of Lancashire and Cheshire, vol. 146, (1997), pp. pp.93-106.

Lovejoy, Paul E., and David Richardson, "Trust, Pawnship, and Atlantic History: The Institutional Foundations of the Old Calabar Slave Trade", American Historical Review, vol. 104, (1999), pp. 333-355.

, "'This Horrid Hole': Royal Authority Commerce and Credit at Bonny, 16901840", Journal of African History, vol. 45, (2004), pp. 363-392.

Matthews, Godfrey W., "John Bolton: A Liverpool Merchant, 1756-1837", Transactions of the Historic Society of Lancashire and Cheshire, vol. 93, (1941), pp. 98-115.

Morgan, Kenneth, "Bristol West India Merchants in the Eighteenth Century", Transactions of the Royal Historical Society, vol. 3, (1993), pp. 185-208. , "James Rogers and the Bristol Slave Trade", Institute of Historical Research, 
vol. 76, no. 192, (May 2003), pp. 189-216.

Nwokeji, G. Ugo, "The Atlantic Slave Trade and Population Density: A Historical Demography of the Biafran Hinterland", Canadian Journal of African Studies, vol. 34, no. 3, (2000), pp. 616-655.

Parkinson, Bradbury B., "A Slaver's Accounts", Accounting Research, vol. 2, (Apr. 1951), pp.144-150.

Price, Jacob M., "Directions for the Conduct of a Merchant Counting House, 1766", Business History, vol. 28, no. 3, (1986), pp. 134-150.

"What Did Merchants Do? Reflections on British Overseas Trade, 16601790", The Journal of Economic History, vol. 49, no. 2, (Jun. 1989), pp. 267284.

Price, Jacob M., and G.E. Clemens, "A Revolution of Scale in Overseas Trade: British Firms in the Chesapeake Trade, 1675-1775", The Journal of Economic History, vol. 47, no. 1, (Mar. 1987), pp. 1-43.

Richardson, David, "The Costs of Survival: The Transport of Slaves in the Middle Passage and the Profitability of the 18th- Century British Slave Trade", Explorations in Economic History, vol. 24, (1987), pp. 178-196.

, "Prices of Slaves in West and West-Central Africa: Toward and Annual Series, 1698-1807", Bulletin of Economic Research, vol. 43, (1991), pp. 2156.

Rogers, Nicholas, "Money, Land and Lineage: The Big Bourgeoisie of Hanoverian London", Social History, vol. 4, no. 3, (Oct. 1979), pp. 437-454.

Sanderson, F.E., "Liverpool and the Slave Trade: A Guide to Sources", Transactions of the Historic Society of Lancashire and Cheshire, vol. 124, (1972), pp. 154176.

, "The Liverpool Delegates and Sir William Dolben's Bill", Transactions of the Historic Society of Lancashire and Cheshire, vol. 129, (1972), pp. 57-84.

Schofield, M.M., "The Virginia Trade of the Firm of Sparling and Bolden, of Liverpool 1788-99", Transactions of the Historic Society of Lancashire and Cheshire, vol. 116, (1969), pp. 117-165.

"A Good Fortune: The Marriage of Christopher Hassell of Liverpool, Merchant 1765", Transactions of the Historic Society of Lancashire and Cheshire, vol. 138, (1989), pp.85-111.

Sheridan, R.B., "The Commercial and Financial Organisation of the British Slave Trade, 1750-1807", Economic History Review, vol. 11, (1958), pp. 249-263.

Stein, Robert, "The Profitability of the Nantes Slave Trade, 1783-1792", The Journal of Economic History, vol. 35, no. 4, (Dec. 1975), pp.779-793.

Stobart, Jon, "Culture Versus Commerce: Societies and Spaves for Elites in Eighteenth-Century Liverpool", Journal of Historical Geography, vol. 28, no. 4, (2002), pp. 471-485.

Thomas, Robert Paul, and Richard Nelson Bean, "The Fishers of Men: The Profits of the Slave Trade", The Journal of Economic History, vol. 34, no. 4, (Dec. 1974), pp. 885-914.

Trepp, Jean, "The Liverpool Movement for the Abolition of the English Slave Trade", The Journal of Negro History, vol. 13, no. 3, (Jul. 1928), pp. 265-285.

Tyler, John W., "Foster Cunliffe and Sons: Liverpool Merchants in the Maryland Tobacco Trade, 1738-1765", Maryland Historical Magazine, vol. 73, no. 3, (Sept. 1978), pp. 246-279.

Warnier, Jean-Pierre, "Traite Sans Raids Au Cameroun", Cahiers d'Etudes Africaines, vol. 29, no. 113, (1989), pp. 5-32. 


\section{$\underline{\text { Online Media }}$}

Anonymous, "Slave Trade Revealed in Historic Papers", BBC News, 2001, available from http://news.bbc.co.uk/2/hi/uk_news/england/1718422.stm

Anonymous, "Ancestor Search in the County of Lancashire", Lancashire Online Parish Clerks, 2009, available from http://www.lan-opc.org.uk/Search/indexp.html

Anonymous, "Antiques Roadshow UK: Broadcast Highlights, Bidduplh", PBS, 2009, available from http://www.pbs.org/wgbh/antiquesuk/highlights/113.html

Anonymous, "Capesthorne Hall: History", Capesthorne Hall, 2009, available from http://www.capesthorne.com/history.html

Phillips, A.E, "Leyland and Bullins", British Banking History, 2003, available from http://www.banking-history.co.uk/leyland.html

Officer, Laurence H., "Purchasing Power of British Pounds from 1264 to Present," Measuring Worth, 2009, available from http://www.measuringworth.com/ppoweruk/

Richardson, David, "A Brief Introduction to the Microfilm Edition of the William Davenport Papers," British Online Archives, 1998, available from http://www.britishonlinearchives.co.uk/9781851171767.php

$\begin{array}{cccc}\text {, "Davenport, William (1725-1797)", Oxford Dictionary of } & \text { National } \\ \text { Biography, } & 2004, & \text { available } & \text { from }\end{array}$ http://www.oxforddnb.com/view/article/55685

Westgraph, Laurence, "Read the Signs: Street Names with a Connection to the Transatlantic Slave Trade and Abolition in Liverpool," English Heritage, 2008, available from

http://www.englishheritage.org.uk/server/show/nav.18287

\section{Online Database}

"Voyages Database," Voyages: The Trans-Atlantic Slave Trade Database, 2008, available from http://www.slavevoyages.org/tast/index.faces 